
INTERVENÇÃO ARQUITETÔNICA

\author{
Tese apresentada ao Departamento de Engenharia \\ de Minas e Petróleo à Escola Politécnica da \\ Universidade de São Paulo para a obtenção do \\ título de Doutor em Engenharia.
}

v.1

São Paulo

2007 


\title{
CONTRIBUIÇÃO À ESCOLHA DE MÁRMORES E GRANITOS NUMA INTERVENÇÃO ARQUITETÔNICA
}

\author{
Tese apresentada ao Departamento de Engenharia \\ de Minas e Petróleo à Escola Politécnica da \\ Universidade de São Paulo para a obtenção do \\ título de Doutor em Engenharia. \\ Área de Concentração: Engenharia Mineral \\ Orientador: Prof. Titular Wildor Theodoro Hennies
}

Exemplar original: 2007

Exemplar revisado: 2007

São Paulo 
Este exemplar foi revisado e alterado em relação à versão original, sob responsabilidade única do autor e com anuência de seu orientador.

São Paulo, de de 2007.

Assinatura do Autor

Assinatura do orientador

FICHA CATALOGRÁFICA

Stellin, Maria Renata Machado

Contribuição à Escolha de Mármores e Granitos numa Intervenção Arquitetônica - São Paulo.-2007- 101p.

Tese (Doutorado) - Escola Politécnica da Universidade de São Paulo.

Departamento de Engenharia de Minas e de Petróleo.

1. Rochas Ornamentais 2. Mármores e Granitos

3. Aplicação de Mármores e Granitos

I. Universidade de São Paulo. Escola Politécnica .

Departamento de Engenharia de Minas e Petróleo.ll.t 


\section{AGRADECIMENTOS}

Ao Prof. Dr.Wildor Theodoro Hennies, meu orientador, por sua orientação segura para a elaboração deste trabalho.

A Chefe de Biblioteca do Departamento de Engenharia de Minas e de Petróleo, Maria

Cristina M. Bonésio, que me deu diretrizes para a apresentação do trabalho.

A professora Doutora e amiga Ana Carolina Chieregati pela disponibilidade e pelo constante acompanhamento.

Ao Professor Doutor Antonio Stellin Júnior pela dedicação e responsável pelo meu constante aprendizado. 


\section{RESUMO}

No presente trabalho abordou-se inicialmente as principais características da indústria de rochas ornamentais, a lavra das jazidas e o beneficiamento, compreendendo a serragem, semitransformação e transformação até os tipos mais importantes de produtos que são normalmente comercializados.

Em seguida, estudou-se as rochas ornamentais desde seus tipos, suas cores, brilhos, suas classificações relativas a gênese, estruturas e valor comercial

Foi dada ênfase especial as cores tanto das rochas como dos ambientes onde elas serão aplicadas, lembrando a influência psicológica das cores com relação aos seres humanos.

Apresentou-se proposta de identificação das cores utilizando recursos atuais da informática, além de uma proposta de criação de um Banco de Dados, com informações específicas de interesse para os projetos de engenharia e arquitetura.

Como exemplo, analisou-se uma aplicação onde utilizou-se o Banco de Dados que foi criado, além de conceitos importantes relativos a uma intervenção arquitetônica. 


\begin{abstract}
In present work, initially was approached the main characteristics of the dimension stones industry, explotation of the deposits and the processing, understanding the sawing semitransformation and transformation, as well the types most important of products that are normally commercialized.
\end{abstract}

After that, one studied the dimension stones from the types, colors and brightness to the relative classifications geneses, strutures and commercial value.

It was given special emphasis to the colors of the rocks as well as the of environments where they will be applied, remembering the psychological influence of the colors related to the human beings.

One presented proposal of identification of colors identification using current resources of computer science, beyond a proposal of creation of a data base, with information of interest for the projects of engineering and architecture.

This work presents, as example, an application, using the data base created, as well as relative important concepts to an architectural intervention. 


\section{SUMÁRIO}

\section{AGRADECIMENTOS}

RESUMO

ABSTRACT

SUMÁRIO

LISTA DE ILUSTRAÇÕES

LISTA DE FOTOS

LISTA DE TABELAS

LISTA DE QUADROS

LISTA DE ABREVIATURAS E SIGLAS

1. INTRODUÇÃO

1.1 Características da indústria de rochas ornamentais 1

1.1.1 Lavra $\quad 5$

$\begin{array}{ll}\text { 1.1.2 Beneficiamento } & 13\end{array}$

$\begin{array}{ll}\text { 1.1.2.1 Espessores e peças artísticas } & 13\end{array}$

$\begin{array}{ll}\text { 1.1.2.2 Serragem } & 13\end{array}$

1.1.2.3 Semi-transformação 15

$\begin{array}{ll}\text { 1.1.2.4 Transformação } & 17\end{array}$

$\begin{array}{lr}\text { 2. OBJETIVOS } & 21\end{array}$

3. REVISÃO BIBLIOGRÁFICA 22

3.1 Tipos de Rochas Ornamentais $\quad 22$

3.1.1 Rochas ígneas $\quad 23$

3.1.2 Rochas sedimentares 23

3.1.3 Rochas metamórficas $\quad 26$

3.2 Cor e Brilho dos Minerais $\quad 28$

3.2.1 Cor das rochas ígneas $\quad 29$

3.2.2 Cor das rochas sedimentares $\quad 30$ 
3.2.3 Cor das rochas metamórficas

3.2.4 Brilho

3.3 Classificação

3.3.1 Segundo sua gênese

3.3.2 Segundo seus usos

3.3.3 Segundo suas estruturas

3.3.4 Classificação comercial pelas cores

4.1 As cores nos ambientes

4.2 Identificação das cores

4.3 Métodos propostos de identificação

4.3.1 Método de comparação direta

4.3.2 Classificação

4.3.3 Comparações entre os sistemas RCC e RGB

5. PROPOSTA DE APRESENTAÇÃO DAS AMOSTRAS DE MÁRMORES E GRANITOS

5.1 Procedimento normalmente utilizado

5.2 Proposta de apresentação das amostras

6. CONSTRUÇÃO DO BANCO DE DADOS DAS AMOSTRAS 75

6.1 Granito

76

6.2 Mármore

7. EXEMPLO DE APLICAÇÃO 


\section{LISTA DE FIGURAS}

Figura 1.1 Aspectos da indústria de rochas ornamentais 2

Figura 1.2 Esquema simplificado das operações industriais 3

Figura 1.3 Planos preferenciais de corte das rochas ornamentais 5

$\begin{array}{ll}\text { Figura 1.4 Corte do granito por meio de chama } & 7\end{array}$

$\begin{array}{ll}\text { Figura 1.5 Corte feito por meio de fio diamantado } & 8\end{array}$

Figura 1.6 Corte por meio de cunhas metálicas 9

$\begin{array}{ll}\text { Figura 3.1 Rochas ígneas. Informações gerais } & 24\end{array}$

$\begin{array}{ll}\text { Figura 3.2 Brecha Calcária } & 44\end{array}$

Figura 3.3 Tipos de Estruturas $\quad 45$

$\begin{array}{ll}\text { Figura 3.4 Estrutura Granítica } & 46\end{array}$

Figura 4.1 Decomposição da luz branca

Figura 4.2 Esfera de Cores de Munsell $\quad 56$

Figura 4.3 Criação do Banco de Dados em Computador $\quad 60$

$\begin{array}{ll}\text { Figura.5.1 Programa Colormania e seus recursos disponíveis } & 64\end{array}$

Figura 5.2.Utilização conjunta de dois programas (Cores combináveis e Color

Detector) na determinação dos valores RGB e Hexagonal equivalentes 65

$\begin{array}{ll}\text { Figura 5.3 Proposta de apresentação das amostras } & 66\end{array}$

$\begin{array}{ll}\text { Figura 7.1 Intervenção Arquitetônica } & \mathbf{8 6}\end{array}$ 


\section{LISTA DE FOTOS}

Foto 1.1 Lavra de granito na Pedreira Fazenda Somibrás 10

Foto 1.2 Rejeito para produção de peças de cantaria 11

Foto 1.3 Frente de lavra da pedreira de mármore de Vargem Grande do

$\begin{array}{ll}\text { Soturno } & 12\end{array}$

Foto 1.4 Tear multilâminas. Vista frontal 15

Foto 1.5 Máquina automática de polimento de chapas 17

Foto 1.6 Serragem longitudinal e transversal das chapas 18

Foto 3.1 Calcário compacto $\quad 37$

Foto 3.2 Calcário nodular $\quad 38$

Foto 3.3.Calcário fossilífero $\quad 39$

$\begin{array}{ll}\text { Foto 3.4 Calcário poroso } & 40\end{array}$

Foto.3.5 Calcário bandeado $\quad 41$

Foto 3.6 Mármore ônix

Foto 3.7 Mármore estratificado

Foto 3.8 Oficalcita $\quad 44$

Foto 3.9 Estrutura porfiritica $\quad 47$

$\begin{array}{ll}\text { Foto 3.10 Estrutura fluidal } & 48\end{array}$

Foto 4.1. Espectrocolorimetro X-RITE 948 da Erichsen 59

Foto 5.1. Visualização das cores claras nos granitos pretos $\quad 69$ 


\section{LISTA DE TABELAS}

Tabela 3.1 Principais tipos de rochas usadas como mármores e granitos

Tabela 3.2 Cor dos minerais mais comuns formadores dos mármores

e granitos

Tabela 3.3 Classificação Tecnológica das Rochas Ornamentais

Tabela 3.4 Classificação Tecnológica das Rochas Ornamentais segundo seus usos

Tabela 3.5 Classificação das Rochas Ornamentais segundo suas estruturas 36

Tabela 3.6 Classificação comercial dos mármores e granitos segundo

grupo de cores

Tabela 3.7 Classificação dos mármores e granitos segundo suas cores

Tabela 4.1 Comparação entre RCC e RGB

Tabela 5.1 Especificações para Rochas Ornamentais

Tabela 5.2 Características tecnológicas importantes de acordo com o uso

Tabela 7.1 Tabelas de cores e respectivos valores de R, R-G, G-B e RGB em 


\section{LISTA DE ABREVIATURAS E SIGLAS}

IPT INSTITUTO DE PESQUISAS TECNOLÓGICAS DO ESTADO DE SÃO PAULO YKK YOSHIDA DO BRASIL LTDA

SOMIBRÁS SOCIEDADE DE MINERAÇÃO BRASILEIRA LTDA

RCC ROCK COLOR CHART

RGB RED GREEN BLUE (SISTEMA DE CORES: VERMELHO, VERDE E AZUL) 


\section{INTRODUÇÃO}

Nas intervenções arquitetônicas sempre é problemática a escolha das rochas ornamentais a serem utilizadas, dada a pouca familiaridade que os projetistas têm com o assunto.

Dentre todas as características, a cor e o brilho se mostram como as mais importantes, sendo importantes também a textura, a estrutura, o padrão, a disponibilidade e o preço.

Além das características físicas da cor, deve-se levar em conta suas características neurofisiológicas que provocam sensações nas pessoas, induzindo não somente a escolha da cor em si, mas também a combinação dela com outras cores de rochas ornamentais e também com cores de outros materiais usados em revestimentos e acabamentos superficiais.

Os Bancos de Dados existentes em catálogos, manuais e CD-ROMs nacionais e internacionais, apresentam as cores dos mármores e granitos de uma maneira confusa e nem sempre esclarecedora quanto aos padrões das amostras apresentadas.

\subsection{Características da Indústria de Rochas Ornamentais}

Assim como a indústria extrativa agro-pastoril, a mineração disponibiliza as matérias primas minerais para a sobrevivência e o bem estar da humanidade. Quando se visita uma pedreira e observam-se as cores e as variações das rochas, fica-se fascinado e pensa-se em transportar para o nosso dia a dia aquele ambiente observado.

A Fig.1.1 extraída dos catálogos da Pellegrini Macchine (2001), serve como ilustração das várias etapas de trabalho pelas quais passam as rochas ornamentais até a obtenção dos produtos finais. 
Observando a Fig. 1.1 as seguintes fases são representadas pelas letras:

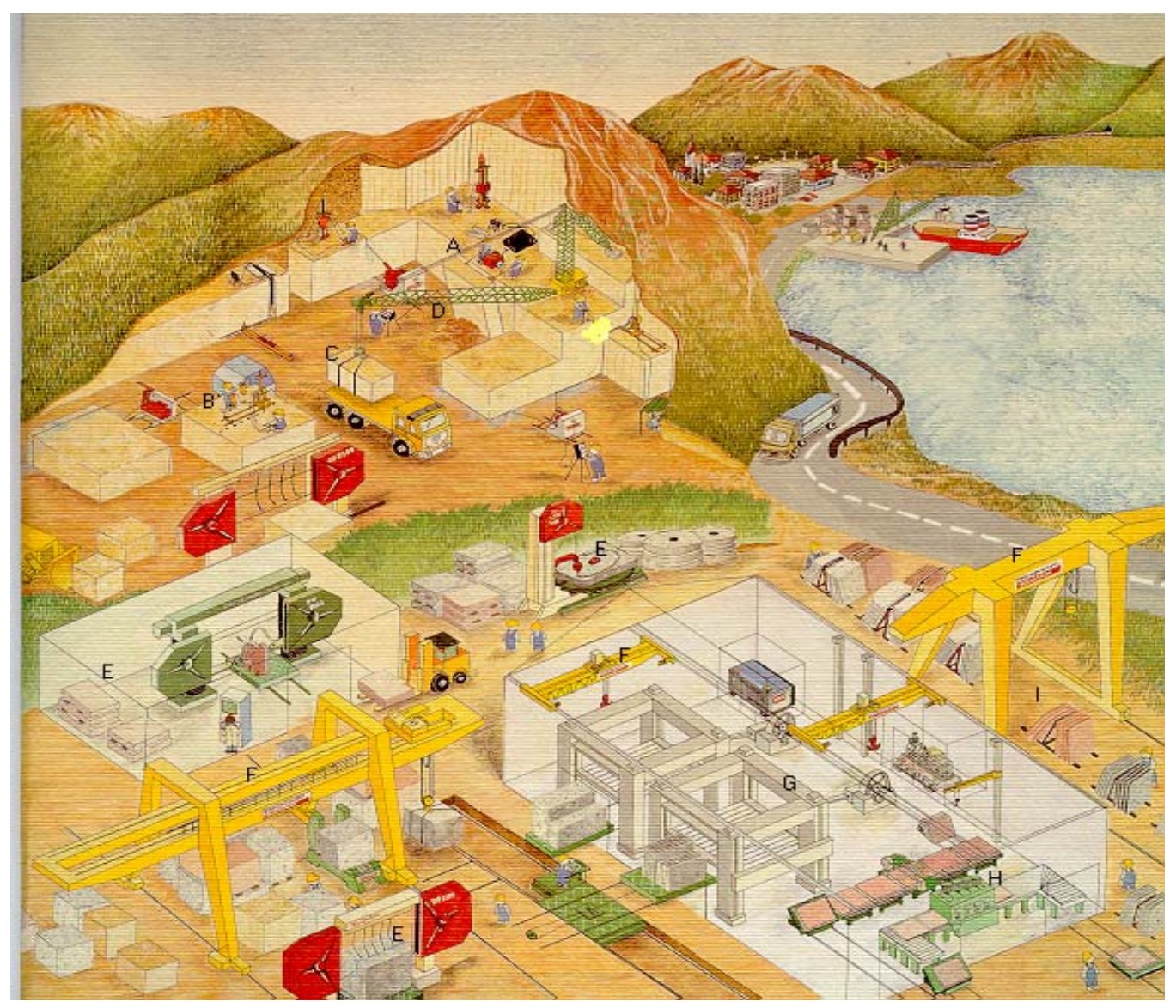

Fig. 1.1 Aspectos da indústria de rochas ornamentais.

Letra A: mostra um bloco primário que foi cortado do maciço rochoso e tombado no pátio da pedreira.

Letra B: mostra um bloco primário sendo recortado em blocos com dimensões compatíveis com as dimensões dos teares de serragem (denominados blocos com dimensões comerciais).

Letras C e D: mostra um desses blocos sendo carregado num caminhão pelo pau de carga.

Letras E: mostram monofios diamantados cortando espessores.

Letras F: mostram as pontes rolantes que descarregam os blocos dos caminhões e também movimentam blocos e chapas na serraria.

Letra G: mostra os teares que realizam a serragem dos blocos. 
Letra H: mostra as operações de acabamento superficial das chapas e o corte das chapas em placas.

Letra I: mostra os locais de armazenamento das chapas e espessores.

As placas geralmente embaladas em caixas de papelão são armazenadas em locais cobertos. O esquema da Fig. 1.2 de Mello Mendes (1974), também auxilia na apresentação dessas várias etapas produtivas. Ele da maior ênfase aos diversos tipos de materiais produzidos durante as várias etapas de trabalho.

Na indústria moderna das rochas ornamentais, as operações podem ser agrupadas em duas fases: Lavra e Beneficiamento, sendo que esta última compreende, segundo Mello Mendes (1974), três operações: serragem, semi-transformação e transformação.

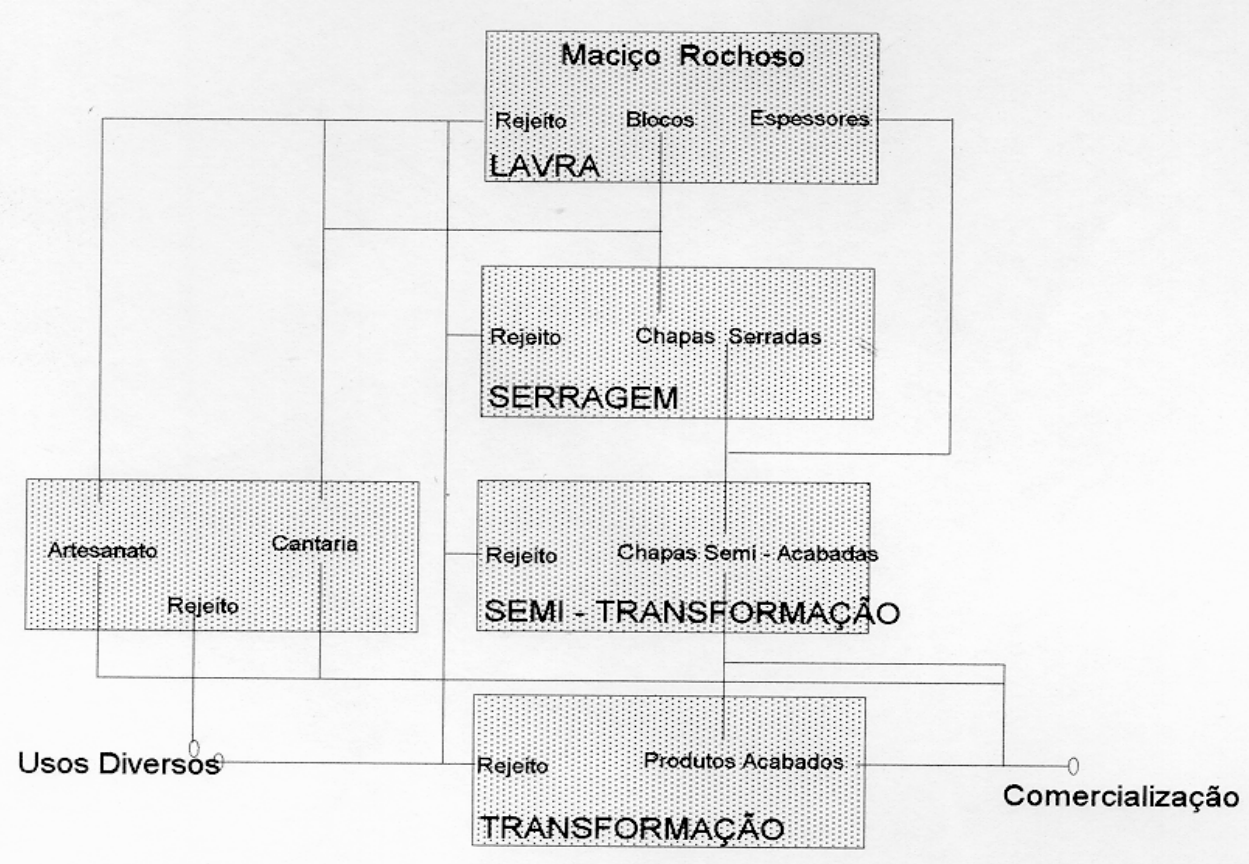

Fig. 1.2 Esquema simplificado das operações industriais. 
Blanco (1993) define trabalhabilidade como sendo a menor ou a maior facilidade que se tem em cortar, serrar, polir e esculpir uma determinada rocha ornamental.

A trabalhabilidade das rochas ornamentais está ligada à cinco propriedades, que são: dureza, resistência ao impacto, serrabilidade, facilidade para se esculpir e facilidade para receber polimento. As rochas magmáticas apresentam três planos preferenciais de corte, que são: corrida, segundo e trincante; as rochas sedimentares apresentam apenas um plano que coincide com o plano de sedimentação; e as rochas metamórficas podem (caso dos gnaisses) ou não (caso dos mármores) apresentar os três planos preferenciais de corte. O mais fácil de ser cortado é o plano da corrida e o mais difícil é o plano do trincante. A Fig. 1.3 extraída de Blanco (1993) mostra, numa frente de trabalho, os três planos mencionados. 


\subsubsection{Lavra}

Caranassios e Stellin Jr. (1991); Vidal (1999) e Vidal et al. (2005) mostram que a primeira etapa dos trabalhos de produção é a lavra da jazida, que compreende de um modo geral as operações de perfuração, desmonte, carregamento e transporte. Na ilustração da Pellegrini Macchine (Fig. 1.1), pode-se notar que o método de lavra é a céu aberto e o desmonte da rocha é feito em bancadas. No caso peculiar das rochas ornamentais, o desmonte é feito por uma série de procedimentos, que sucintamente podese descrever como:

1) Corte da rocha mediante o uso de fio diamantado ou helicoidal.

2 ) Corte da rocha usando-se cortadora de cinta diamantada ou corrente de widia.

3 ) Corte utilizando-se furos de mina coplanares com uso de explosivos ou cunhas de aço.

4) Corte por chama.

5) Corte através do jato d’água.

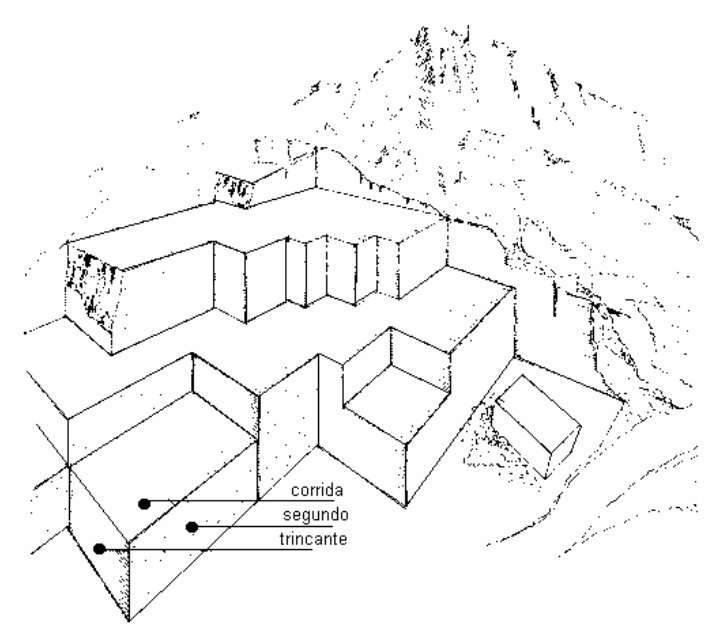

Fig. 1.3 Planos preferenciais de corte das rochas ornamentais.

Observando-se a Fig. 1.1, nota-se que o desmonte da bancada para obtenção dos blocos, em formato e dimensões comerciais, se faz em duas etapas. Na primeira etapa, corta-se um bloco de grandes dimensões, que é tombado na praça da pedreira e que posteriormente é recortado em blocos de dimensões comerciais. A maioria dos compradores de blocos recomenda que as dimensões dos blocos a serem serrados nas 
suas instalações tenham comprimento entre 3,20 e 2,40 metros, sua largura entre 1,90 e 1,20 metros e sua altura entre 1,90 e 1,00 metros, evidentemente dando preferência a dimensões maiores devido ao melhor aproveitamento do tear.

O desmonte de matacões diverge um pouco do que foi apresentado, porém não se entrará em maiores detalhes, por estarem se extinguindo as ocorrências desse tipo. Os blocos com dimensões comerciais são carregados em caminhões por meio de pau de carga e são transportados para pátios de estocagem, que são geralmente localizados:

1) Na própria pedreira.

2) Nas proximidades de portos de embarque.

3) Nas usinas de beneficiamento.

A retirada dos blocos dos caminhões é feita por meio de pontes rolantes, que podem ser vistas na Fig. 1.1. As pontes rolantes são muito utilizadas nas usinas em operações de carga e descarga de blocos e chapas.

As pedreiras brasileiras são lavradas a céu aberto e o desmonte feito em bancadas. Os blocos primários de grandes dimensões são isolados do maciço para serem posteriormente recortados em unidades menores, nas dimensões comerciais.

As dimensões dos blocos primários dependem das dimensões dos blocos comerciais, das juntas de alívio, e dos planos de trabalhabilidade nos granitos, enquanto que nos mármores quando metamórficos, esses planos não são evidentes, a não ser os calcários sedimentares que apresentam planos de estratificação.

Os procedimentos de corte mais empregados nas pedreiras de mármores e granitos no Brasil, são descritos a seguir.

O corte de granito por meio de chama feito por maçarico, extraído de Pellegrini Macchine (2001), é mostrado na Fig. 1.4. Ele queima uma mistura de óleo diesel e ar comprimido. Esse tipo de corte é aplicável em granito com elevado teor de quartzo. 

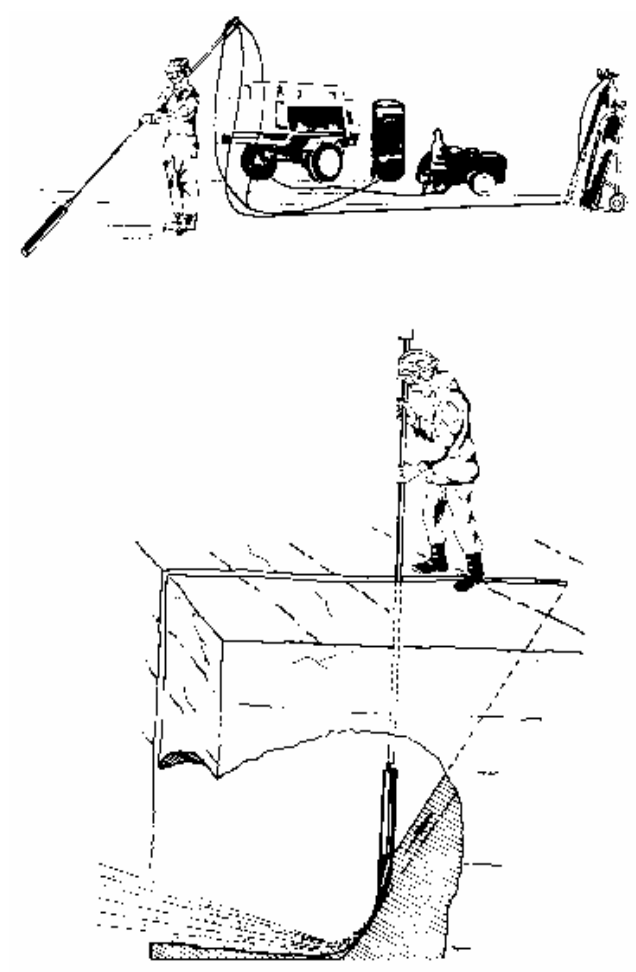

Fig. 1.4. Corte do granito por meio de chama.

Segundo Hennies e Stellin Jr. (2000) o corte feito por fio diamantado, esquematicamente mostrado na Fig.1.5.,é aplicado nas pedreiras de rochas ornamentais brasileiras tanto para mármores como para granitos. 

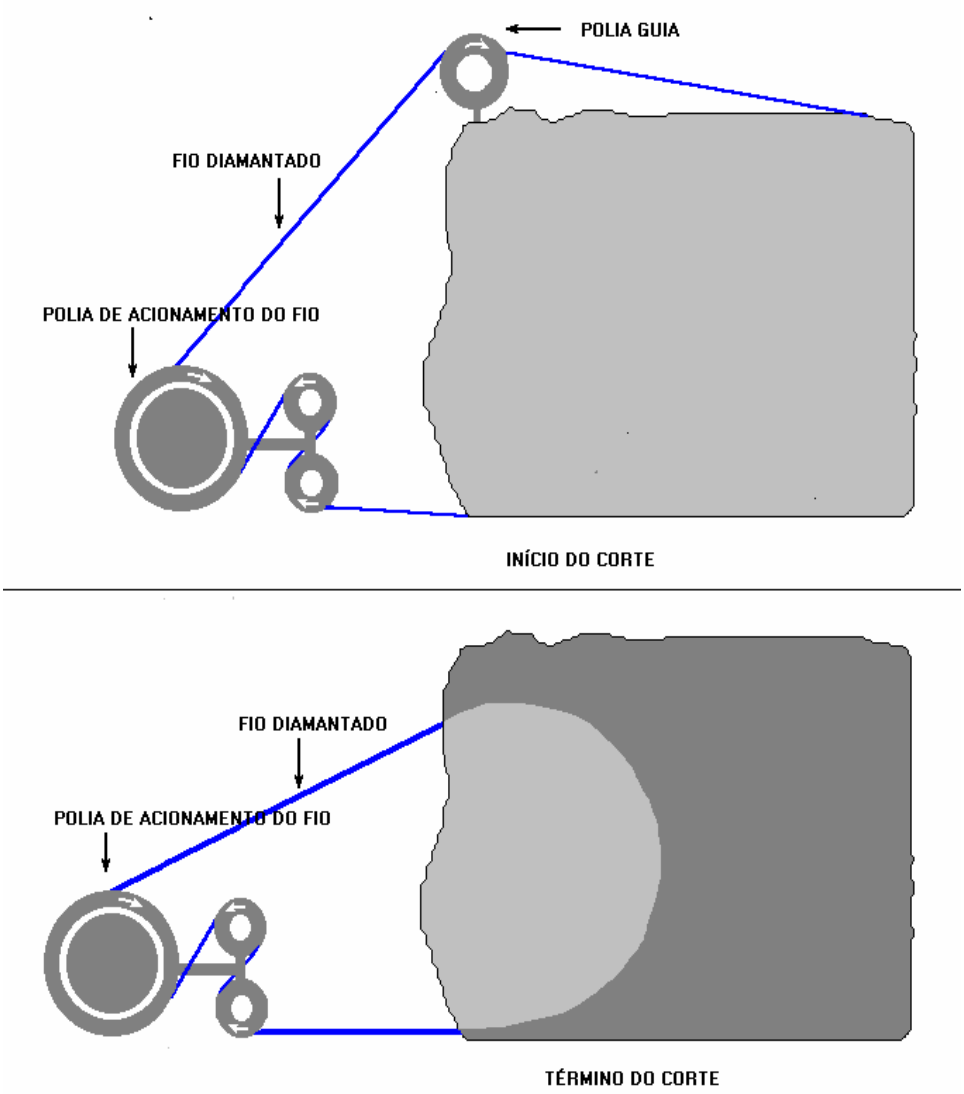

Fig. 1.5 Corte feito por meio de fio diamantado.

A posição da polia de acionamento do fio diamantado pode ser vertical ou horizontal, permitindo, assim, que a máquina realize cortes em planos horizontais e verticais.

O corte feito por cunhas de aço, Fig.1.6, extraído dos catálogos da Pellegrini Macchine (2001), pode ser feito em planos horizontais e verticais. 

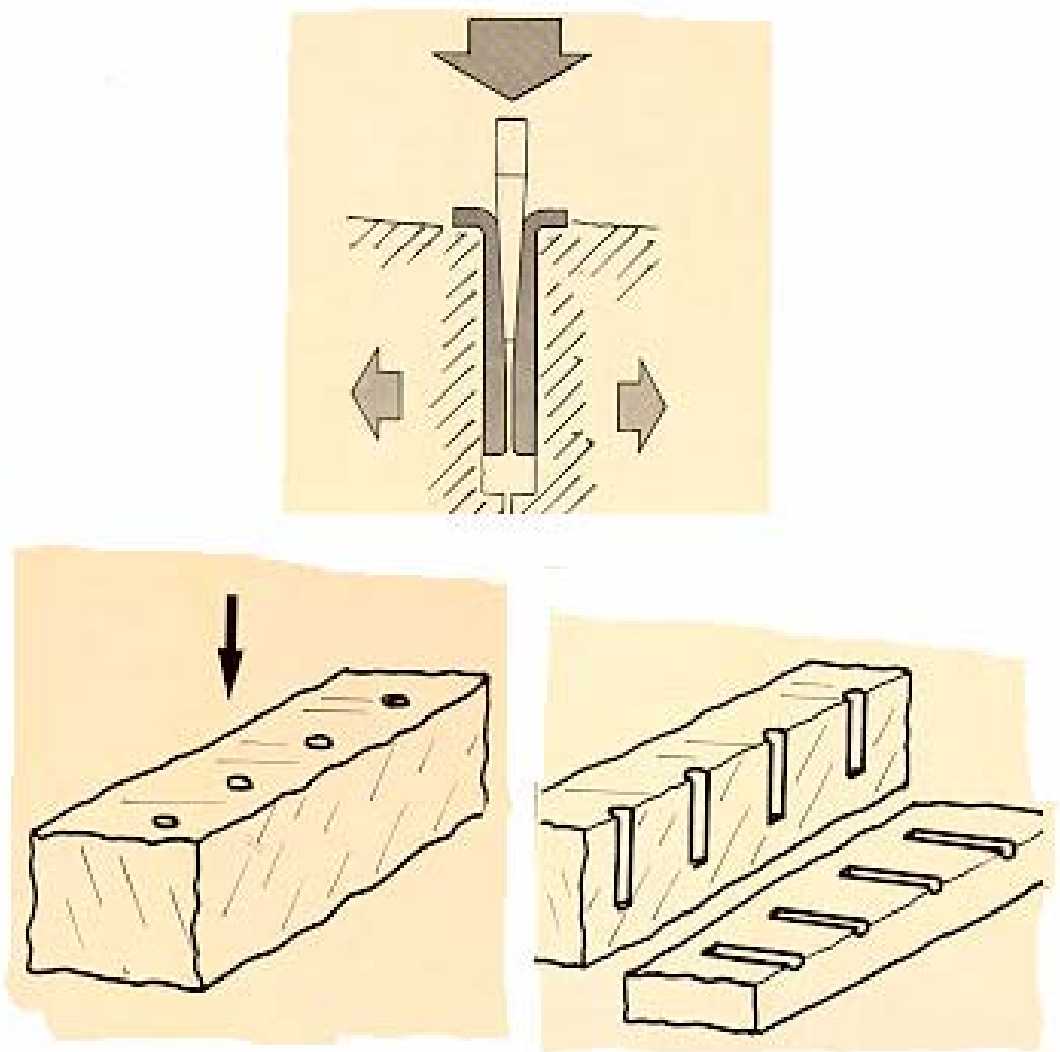

Fig. 1.6 Corte por meio de cunhas metálicas.

Esse tipo de corte é aplicável tanto para mármores como para granitos. Como exemplo de exploração de granito, na Foto 1.1 mostra-se o desmonte da bancada do nível intermediário da pedreira Fazenda Somibrás, explorada pela Empresa Somibrás Mineração Brasileira Ltda., no município de Capão Bonito (SP). Segundo Stellin Jr.(2.003) e Filipov (2002), o desmonte de um bloco primário, cujas dimensões situam-se entre $10 \times 10 \times 2$ metros, é feito a partir da face da espessura, que corresponde ao trincante e da parte inferior do bloco primário, através do corte por chama. O corte correspondente a altura do bloco é feito por meio de cunhas de aço, que promovem o tombamento do bloco no piso da bancada. O recorte do bloco primário em blocos de dimensões comerciais é feito também por cunhas de aço. Seguem abaixo os detalhes da Foto 1.1 que são apresentados através de letras: 


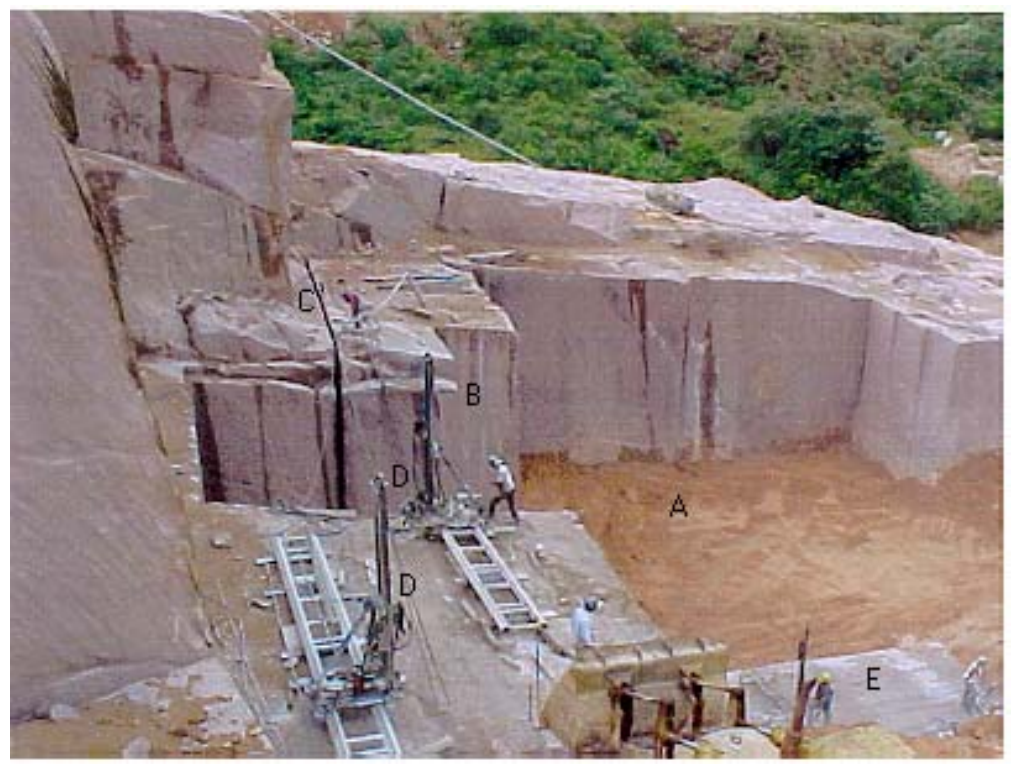

Foto 1.1 Lavra de granito na pedreira Fazenda Somibrás.

Fonte: Acervo particular.

Letra A: praça da pedreira.

Letra B: bloco primário que será tombado na praça da pedreira, aparecendo a face do trincante que foi cortado por chama.

Letra C: corte feito por cunha na face vertical traseira do bloco.

Letra D: as perfuratrizes que executam os furos de mina.

Letra E: bloco primário sendo recortado em blocos de dimensões comerciais. 
Nas operações de desmonte são gerados os seguintes tipos de materiais:

1 ) solo de decomposição do granito que é utilizado principalmente no revestimento de leito de estrada e também em aterros.

2 ) blocos de forma paralelepipedal facilmente comercializados.

3 ) blocos de forma paralelepipedal, porém com defeitos(trincas, variações de cor, veios pegmatíticos, etc. ).

4) blocos pequenos, com forma irregular que são aproveitados para produzir paralelepípedos, guias e outros produtos de cantaria.

5 ) fragmentos de granito, que são aproveitados como brita no revestimento de estradas.

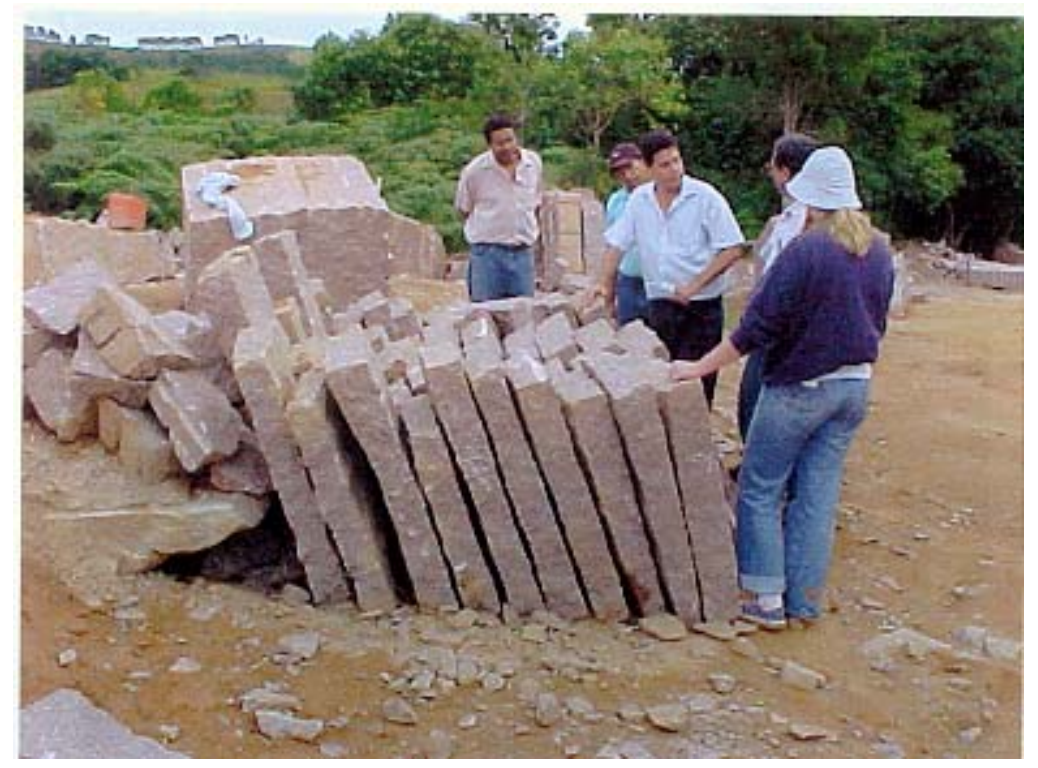

Foto 1.2 Rejeito para produção de peças de cantaria.

Fonte: Acervo particular.

Tem sido muito preocupante para as empresas de mineração o impacto ambiental criado pela exploração das suas jazidas. $\mathrm{O}$ empenho que se nota atualmente nas atividades de mineração é tentar aproveitar os produtos considerados como rejeito, segundo Mastrella et al. (2001). O retorno econômico é satisfatório e tem incentivado muitos trabalhos de pesquisa, como os de Pontes (2001) e Almeida (2001). 
O aproveitamento dos blocos com defeitos vem contribuir para minimizar o impacto ambiental gerado pelas atividades de lavra. Stellin (2.003) e Vidal et al (1999) na análise das observações da visita de campo, indicaram que seria possível o aproveitamento da maior parte dos chamados blocos com defeito na produção de chapas com grandes dimensões. Os blocos com trinca são geralmente aproveitados nos serviços de cantaria ou mesmo por meio do uso de talhabloco. Não se tem notícias que alguma Empresa do setor utilize talhabloco para serrar o granito Capão Bonito.

No caso dos mármores pode-se citar como exemplo a pedreira Vargem Grande do Soturno, situada no município de Cachoeiro de Itapemirim (ES), de propriedade da Marbrasa Mármores Brasileiros S/A. A frente de lavra tem cerca de 80 metros de altura; os cortes principais dos blocos primários são feitos por fio diamantado e o recorte, para se obter blocos em dimensões comerciais, são feitos por cunhas. Aspetos da lavra podem ser vistos na Foto1.3.

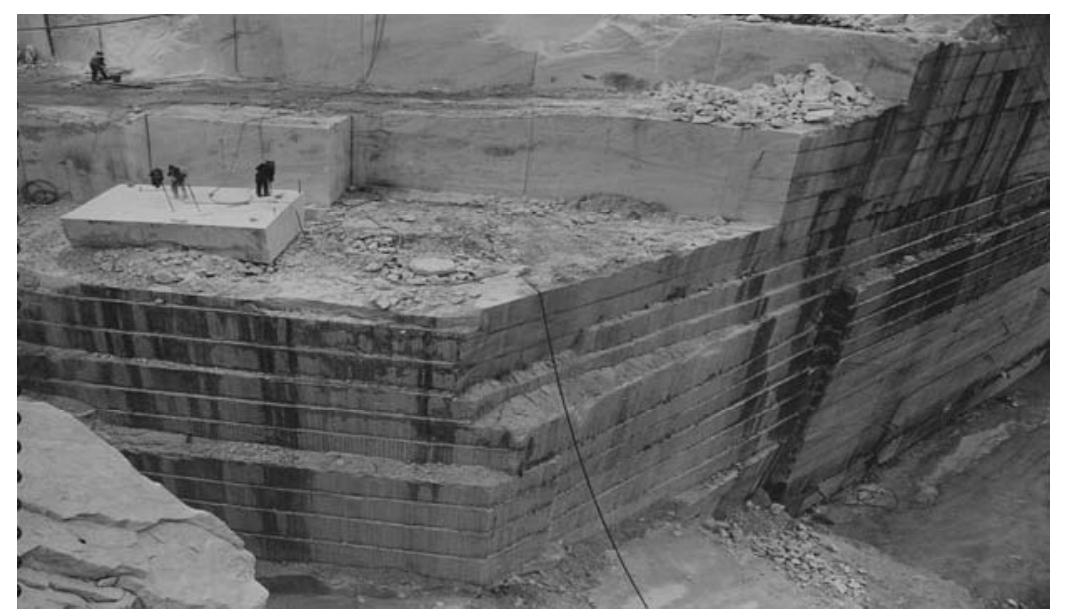

Foto.1.3 Frente de lavra da pedreira de mármore de Vargem Grande do Soturno. Fonte : Acervo particular. 


\subsubsection{Beneficiamento}

O beneficiamento é feito nas unidades fabrís como mostra a Fig. 1.1 e pode ser dividido, segundo CANAVESIO (1977), em três grupos: Espessores e Peças Artísticas, Serragem e Transformação. A divisão proposta por Canavesio (1977) altera a proposta de Mello Mendes (1974), apresentada na Fig. 1.2 , aplicável às operações industriais, englobando a semi- transformação e a transformação numa única atividade que chamou de transformação e acrescentando os espessores e as peças artísticas. Atualmente as indústrias lapídeas adotam a descrição da semi-transformação e da transformação separadamente.

\subsubsection{Espessores e Peças Artísticas}

O produto acabado se caracteriza pelo grande valor artístico, tais como, estátuas, lápides, monumentos, etc. As chapas com grande espessura com relação às chapas serradas em teares multilâminas, recebem a denominação de espessores. É recomendável que o artesão escolha na pedreira o bloco que deverá utilizar, verificando principalmente o padrão e suas variações, para que possa obter um resultado desejado no seu trabalho. Segundo CAMI E SANTAMERA (2001) cada artista tem suas preferências quanto à escolha de ferramentas que irá utilizar, desde ferramentas manuais, até as máquinas modernas, como monofio diamantado na Fig. 1.1 temos exemplos de monofio diamantado operando tanto na pedreira quanto na usina (indicado nas letras E), ferramentas pneumáticas de percussão, jato d'água a alta pressão e raio laser. Muitas vezes os blocos com defeitos são os escolhidos, principalmente quando se desejam efeitos especiais.

\subsubsection{Serragem}

A obtenção de chapas a partir de blocos constitui o primeiro passo para valorização do material a ser extraído da pedreira. É uma fase que inevitavelmente apresenta rejeito, principalmente gerado pela abertura do corte, pelas costaneiras que são as laterais do bloco e também pela regulagem da espessura das chapas, para se ter ambas as faces planas. 
Quando as chapas são destinadas a venda, é comum se exigir dimensões mínimas para comercialização, que raramente são menores que 1,80 x 1,00 metros. Quanto a espessura, é comum se adotar uma tolerância de mais ou menos um milímetro com relação a espessura nominal.

A serragem de blocos por teares multilâminas, produz chapas de grandes dimensões e pequena espessura, da ordem de 1 a 6 centímetros, sendo mais comum as chapas com 1, 2 e 3 centímetros de espessura. Essas chapas são cortadas para obtenção de placas de várias dimensões, utilizadas para revestimento de pisos e paredes das edificações. Atualmente, segundo Stellin Jr. (1998) são utilizados em larga escala teares multilâminas, do tipo:

1 ) tradicional, cuja serragem dos blocos é obtida pela ação do movimento pendular do quadro de lâminas, com ajuda de uma polpa abrasiva. A polpa abrasiva é constituída por uma mistura de água, granalha de aço e cal que evita a oxidação da lâmina e da granalha de aço.

2 ) tipo diamantado, cuja serragem é obtida pela ação de lâminas de aço que possuem na sua parte inferior incrustações de diamantes. O movimento do quadro de lâminas é horizontal e o resfriamento das lâminas se faz pelo uso de água durante a serragem.

Também se utiliza a serragem por talhablocos, que são constituídos por discos diamantados de grande diâmetro. A espessura da peça se obtêm regulando o espaçamento entre os discos. A profundidade do corte feito pelo talhabloco corresponde a 1/3 do diâmetro dos discos. Ele pode serrar blocos pequenos e de forma não paralepipédica. É uma maneira de se aproveitar blocos de forma irregular e que não são indicados para serragem em teares multilâminas. Por motivos econômicos, nem sempre é possível a utilização do talhabloco.

A serragem dos blocos de rochas ornamentais mais utilizada é feita em teares multilâminas, utilizando polpa abrasiva constituída por granalha de aço, água e cal. O corte abre sulcos com largura pouco superior à largura da lâmina. A penetração da lâmina na rocha durante o corte tem uma velocidade de descida denominada cala. À medida que se efetua o corte, aumenta a quantidade de partículas de rocha e de granalha fina na polpa 
circulante, que são eliminadas do circuito por meio de hidrociclones. Um aspecto importante, para o trabalho, é saber a quantidade, em metros quadrados de chapa que se produz por metro cúbico de bloco que é serrado (Stellin; 2003). A Foto 1.4. extraída de catálogos da MECÂNICA GERAL E MÁQUINAS LTDA. (1998), mostra um tear do tipo descrito.

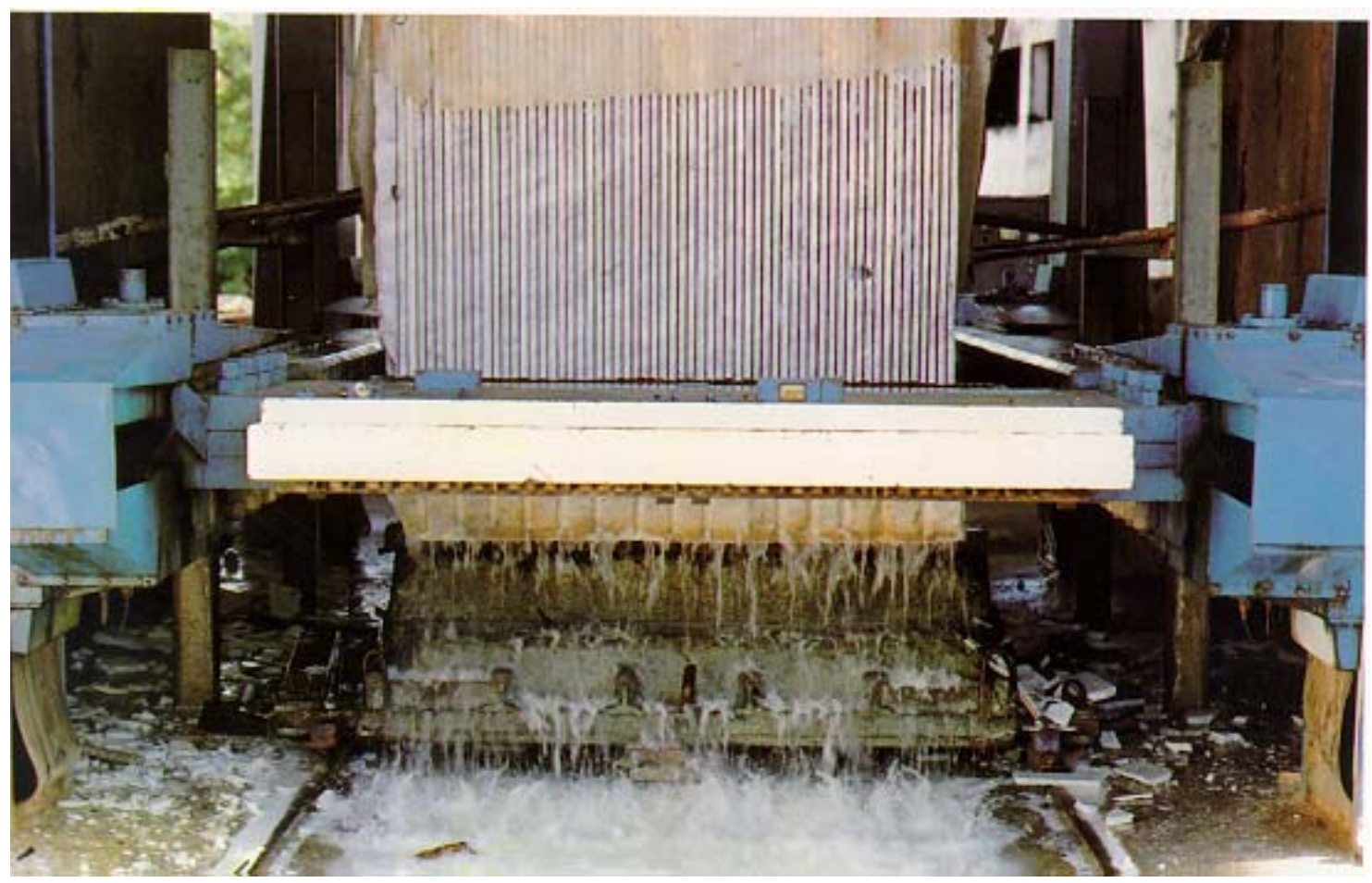

Foto 1.4 Tear multilâminas.Vista frontal.

\subsubsection{Semi - Transformação}

A distinção entre semi-transformação e transformação é meramente convencional. A semi-transformação compreende uma fase intermediária entre a serragem das chapas e o acabamento das peças. Esta fase compreende as operações que dão acabamento as superfícies das chapas. Os tipos mais comuns são: 
1 ) superfície rugosa: são obtidas por percussão sobre a superfície da chapa utilizando-se ferramentas manuais, como, masseta, punção, cinzel com extremidade pontuda simples ou múltipla e marretas com batente de pontas múltiplas. Quando o nível de produção for significativo se utilizam máquinas apropriadas.

2 ) superfície lisa: as superfícies lisas são obtidas pela ação de abrasivos e polidores. As mais utilizadas são: a levigada, com aspecto fosco e a polida que ressalta a beleza das rochas, mostrando a intensidade das cores dos seus minerais constituintes.

3 ) superfície flameada: é uma superfície irregular com aspecto sedoso, obtida pela ação direta de uma chama sobre a superfície da chapa.

Todas essas operações geram uma quantidade de resíduos significativa.

Geralmente, no Brasil, são feitos dois tipos principais de acabamento superficial das chapas; polimento e flameamento. No polimento se utilizam máquinas automáticas de várias cabeças, dotadas de movimento pendular, que agem sobre as chapas que se deslocam sobre uma esteira de borracha com movimento de translação. As cabeças possuem motores elétricos que giram um dispositivo contendo abrasivo, que são de grana cada vez mais fina à medida que as cabeças se sucedem, terminando com os abrasivos que conferem polimento e lustro nas chapas. Uma máquina desse tipo, com 11 cabeças pode ser vista na Foto 1.11., extraída do ISTITUTO NAZIONALE COMMERCIO ESTERO (1982).

O flameamento, aplicável somente em rochas ígneas de estrutura granitóide, consiste em se fazer incidir uma chama em alta temperatura com inclinação de $45^{\circ}$ sobre a superfície da rocha. O efeito de vitrificação superficial dos silicatos confere à rocha um aspecto sedoso característico, com notável resistência ao ataque químico.

Após os tratamentos superficiais as chapas são submetidas a processo de regularização da espessura. 


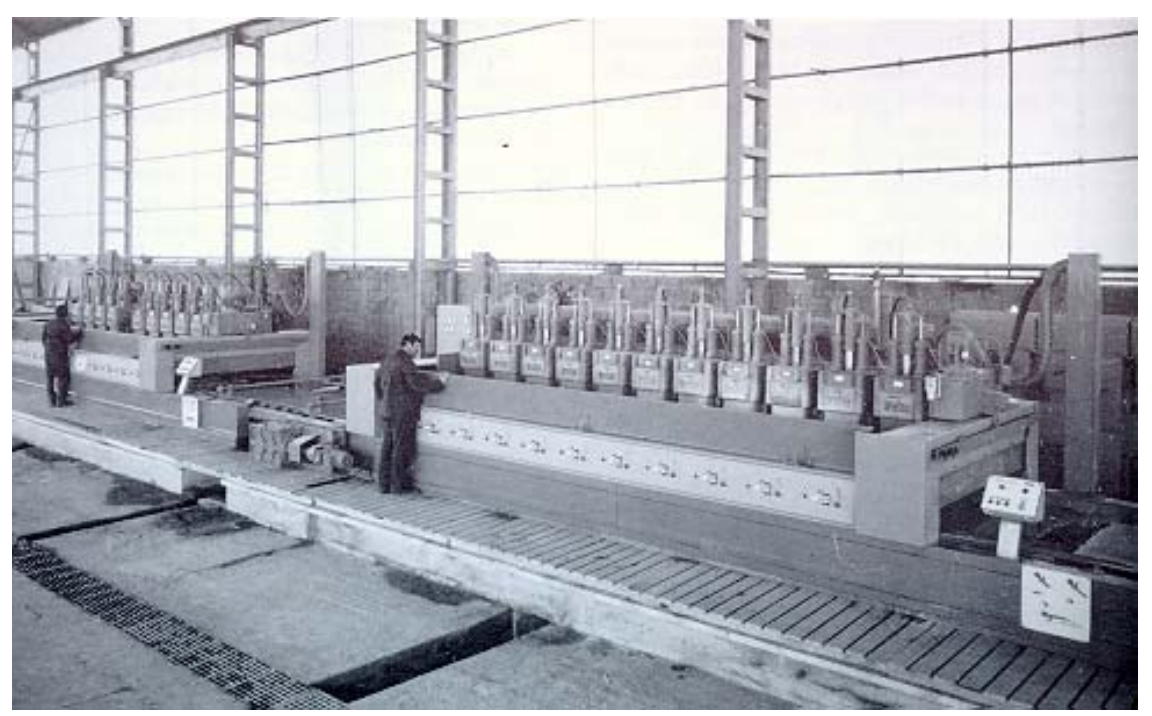

Foto 1.5 Máquina automática de polimento de chapas

\subsubsection{Transformação}

Esta fase compreende as operações finais com a finalidade de colocar os produtos em condições de atender as especificações para uma determinada aplicação. Os tipos de operações são muitas, dependendo de cada caso específico. Dentre os mais importantes, citam-se:

1) serragem das chapas utilizando disco diamantado. Essa operação compreende a retirada das bordas das chapas (oriunda da superfície do bloco) e também a serragem das chapas em placas com dimensões para um determinado uso.

2) acabamento das bordas das placas. Existe um grande número de tipo de acabamento que podem ser feitos para atender as especificações desejadas.

3) retoque no acabamento da superfície. São raramente feitos, mas podem ser necessários em espessores, obras de arte e chapas.

No Brasil as usinas de beneficiamento são denominadas Serrarias. As marmorarias executam, atualmente, apenas o trabalho de transformação. 
Na obtenção de placas com tamanhos padronizados as chapas são cortadas por serras circulares a diamante, longitudinalmente e transversalmente em máquinas semelhantes a que pode ser vista na Foto 1.6 extraída do ISTITUTO NAZIONALE COMMERCIO ESTERO (1982), gerando placas de tamanhos padronizados. As bordas das placas podem sofrer processos específicos de acabamento, dependendo das suas aplicações. Em seguida elas são secas por meio de jato de ar e posteriormente embaladas.

Para baratear e facilitar a comercialização, as chapas são serradas em dimensões padronizadas, tais como: 30 x 30, 40 x 40 ou 50 x 50 centímetros, nas espessuras de 1, 2 e 3 centímetros.

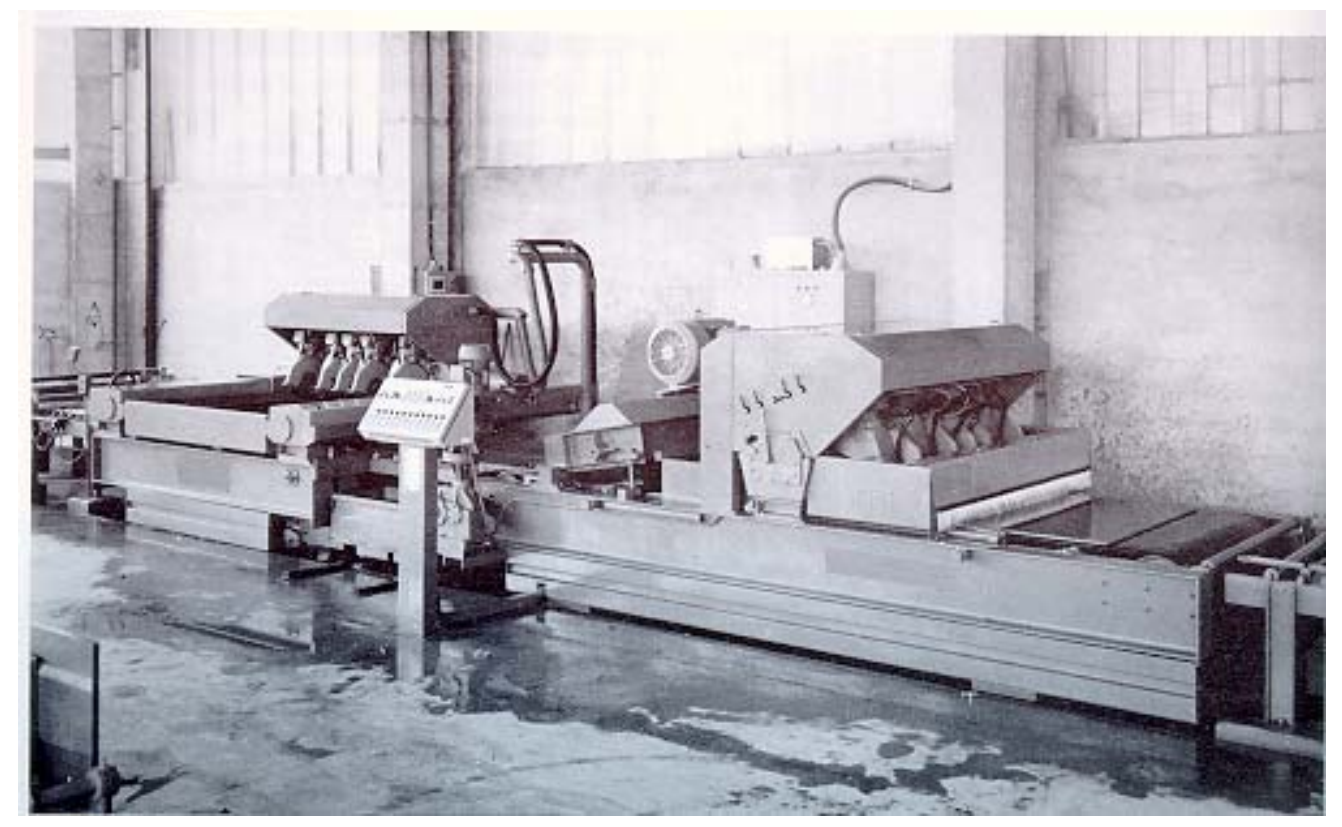

Foto 1.6 Serragem longitudinal e transversal das chapas

As rochas ornamentais são produtos naturais. Em razão disso, ao contrário dos produtos artificiais, possuem características de originalidade, que tem se constituído em material de prestígio reconhecido por todos. É evidente que as peças produzidas pelo mesmo bloco e os manufaturados não podem ser idênticos e que a colocação na obra deve ser feita com critérios profissionais para valorizar ao máximo possível as prerrogativas naturais do material. No caso de grandes projetos, é comum por parte do projetista conhecer a pedreira, de modo que possa ter idéia da potencialidade e da homogeneidade da jazida. 
Na realidade, a questão geralmente exprime no geral a real capacidade do cliente não só em compreender o caráter natural da rocha ornamental, mas também em reconhecer e distinguir nas suas estruturas variações nos seus desenhos e cores, um toque exclusivo, não encontrado em outros produtos. No mais, entre as razões que tem dado lugar ao sucesso dos produtos lapídeos, bem longe das passageiras sugestões da moda, deve-se certamente incluir sua genuinidade ou pureza, da qual deriva a competência para interpretações realmente autênticas, por parte do arquiteto e do projetista.

A modernização das indústrias de rochas ornamentais tem procurado automatizar as suas operações de modo a ter, como produto final, placas com dimensões padronizadas, tendo como objetivo principal a obtenção de produtos a baixo custo, procurando competir com outras indústrias de pisos e revestimentos.

As operações principais observadas nas indústrias de rochas ornamentais compreendem: serragem em teares diamantados ou de granalha abrasiva; desbaste, polimento em máquinas automáticas com mais de uma dezena de politrizes, outros acabamentos superficiais como flamagem, apicoamento, etc; regularização da espessura das chapas e finalmente o corte por serras diamantadas na forma de placas padronizadas.

Para que isso possa ser realizado a custo compatível, é necessário que os blocos extraídos das pedreiras tenham uniformidade de padrão com ausência de defeitos, tais como, variações de cor, trincas, mulas, cordões, barbantes, rabo de galo, etc.

Sabe-se que pela própria origem da rocha ornamental, blocos com defeitos serão extraídos para que a lavra prossiga normalmente. É costume se classificar os blocos em três categorias: $1^{\mathrm{a}}$ (sem defeitos), $2^{\mathrm{a}}$ (com poucos defeitos) e $3^{\mathrm{a}}$ (com muitos defeitos), os valores por metro cúbico do bloco de $2^{\mathrm{a}}$ e de $3^{\mathrm{a}}$ correspondem a $1 / 2$ e $1 / 3$ do valor do bloco de $1^{\mathrm{a}}$. O mesmo critério se aplica para o caso das chapas.

Somente são aceitos blocos de $1^{\mathrm{a}}$ categoria para exportação. Com a modernização da indústria nacional não existe mais interesse na compra de blocos com defeitos. Esses blocos estão sendo armazenados nos pátios das pedreiras com grandes prejuízos para o 
minerador o aproveitamento econômico desses blocos foi proposto por Stellin Jr.(2003). realizando serragem planejada de blocos com auxilio de software da DATAMINE, montando um Banco de Dados das chapas resultantes da serragem tanto no plano da corrida como no plano do segundo. São analisados aspectos econômicos e apresentados exemplos de aplicações com desenhos variados utilizando o Banco de Dados. 


\section{OBJETIVOS}

O objetivo do presente trabalho é propor um novo critério para a apresentação e definição das cores, das rochas ornamentais, visto a deficiência que existe atualmente devido a dificuldade da identificação das cores através dos métodos existentes como por exemplo: catálogos de fornecedores e várias nomenclaturas que são dadas para uma mesma rocha ornamental.Sendo muito importantes as características como a textura, a estrutura, o padrão e destacando o brilho e a cor considerando também a disponibilidade da rocha para sua aplicação.

Serão analisadas de um modo geral todas as características das rochas ornamentais e em especial a cor nas suas formas de serem denominadas e determinadas.

Pretende-se propor critérios mais tecnológicos e práticos na apresentação e na definição das cores das rochas ornamentais tanto no campo como em laboratório. Será criado um Banco de Dados dos principais tipos de mármores e granitos nacionais, inclusive alguns tipos estrangeiros onde aparecerão, foto, cor pelo sistema RGB, desenho da rocha, valor, origem, brilho, tipo de aplicação, disponibilidade, aparência, nome comercial, acabamento superficial, enfim, todas as informações importantes para projetos de rocha ornamentais.

Será apresentado um exemplo de intervenção arquitetônica mostrando a importância das aplicações das várias considerações citadas, objetivando tornar mais concretas as propostas. 


\section{REVISÃO BIBLIOGRÁFICA}

\subsection{Tipos de Rochas Ornamentais}

Segundo Tyrrell (1956); Williams et al. (1976) as rochas são classificadas em três grandes grupos, baseados na sua origem:

1. Rochas ígneas ou magmáticas resultantes da cristalização de um magma fundido que pode se dar a grandes profundidades ou na superfície da crosta terrestre. A textura dessas rochas depende das condições de cristalização. Granitos, gabros, basaltos e pórfiros são exemplos desses tipos de rochas.

2. Rochas sedimentares, formadas pela concentração de fragmentos de vários tamanhos e formas, depositadas por meios mecânicos, por precipitação ou pela acumulação de esqueletos e carapaças orgânicas. Conglomerados, brechas, arenitos, mármores calcíticos e dolomíticos, travertinos e ônix, são exemplos mais comuns desses tipos de rochas.

3. Rochas metamórficas derivadas das rochas ígneas ou sedimentares recristalizadas pela ação de altas pressões e temperaturas. Rochas importantes desse grupo são os gnaisses, mármores cristalinos e quartzitos.

A composição mineralógica, a textura, a estrutura e a cor são características importantes das rochas.

Entende-se por textura da rocha os aspectos geométricos das partículas componentes, incluindo seu tamanho, forma e arranjo.

O termo estrutura da rocha esta relacionada a outras características, como acamamento, fraturas, clivagens, bandeamento, dobras etc.

Como o objetivo do presente trabalho não é o estudo petrográfico das rochas, mas a objetividade na escolha dos mármores e granitos do ponto de vista da arquitetura, muitas vezes será usado o termo desenho da rocha, que de uma maneira simples, porém objetiva, englobaria os aspectos de textura e estrutura da rocha. 


\subsubsection{Rochas ígneas}

Se o processo de resfriamento do magma fundido é lento, a grandes profundidades, a cristalização dos minerais é lenta resultando em cristais grandes. Assim são formados os granitos, os sienitos, os dioritos e os gabros. Se o processo de resfriamento se da próximo à superfície, o resfriamento do magma será rápido, promovendo uma cristalização rápida e conseqüentemente cristais de menores dimensões, formando os felsitos e basaltos, de granulação fina, ou pórfiro, mistura de grãos grossos e finos

As rochas ígneas se apresentam como granitos brancos a gabros e basaltos escuros. Os magmas ácidos, ricos em sílica, cristalizam-se em rochas geralmente com alto teor de ortoclásio, quartzo, mas pobre em minerais escuros como hornblenda e mica escura. Ao contrário, os magmas básicos, pobres em sílica, cristalizam-se em rochas mais escuras com altos teores de hornblenda e plagioclásio de cor cinza a preta. A cor das rochas ígneas depende principalmente da cor do feldspato mais abundante, geralmente com teores em torno de 50 a 75\%. A cor dos granitos e sienitos pode ser branca, rosa ou vermelha, enquanto que dioritos e gabros se apresentam nas cores cinza e preta. $\mathrm{O}$

quartzo nos granitos aparece com teores de 10 a 35\%. Os sienitos praticamente não contem quartzo, apresentando alto teor de minerais escuros.

A Fig. 3.1, extraída de Bradley (1998), mostra uma classificação simplificada das rochas ígneas de acordo com a descrição feita anteriormente.

\subsubsection{Rochas sedimentares}

As rochas sedimentares se formam pela acumulação de fragmentos de rocha ou de solos que são transportados hidraulicamente por correntes ou ondas ou pelo vento, por acumulação orgânica ou por precipitação química. Forma-se uma estrutura plana constituída por camadas sucessivas denominadas estratos. 


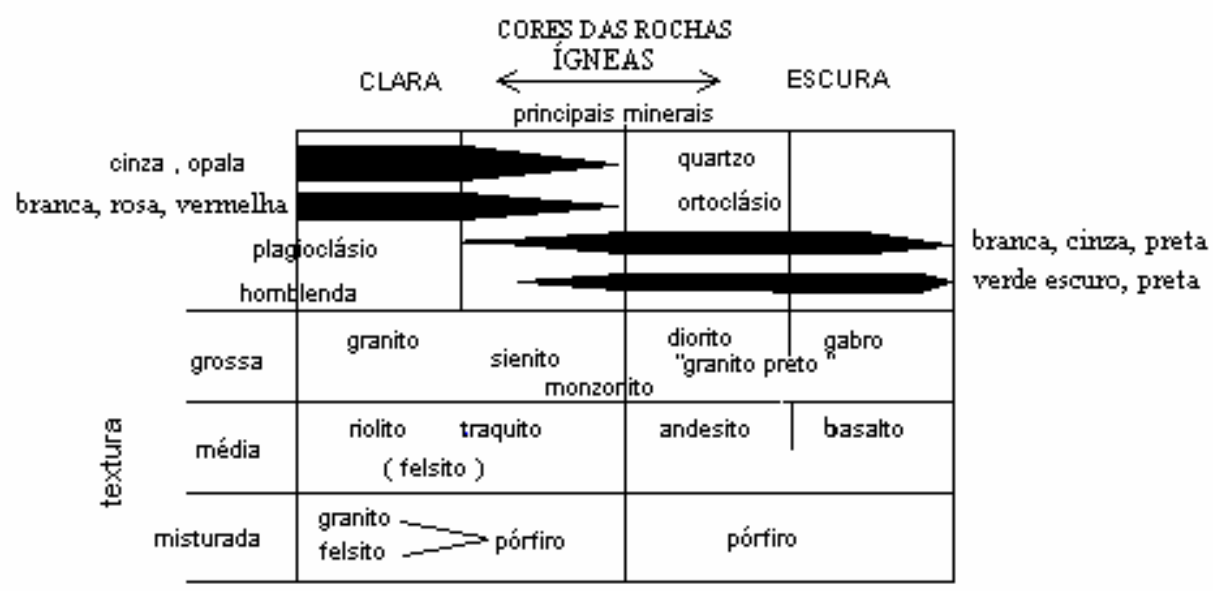

Fig. 3.1 Rochas ígneas. Informações gerais.

As características físicas das rochas sedimentares dependem preliminarmente da composição mineral, da textura, da estrutura e no caso dos sedimentos clásticos, do cemento entre os fragmentos. As rochas sedimentares são geralmente classificadas como:

a) Sedimentos clásticos, com fragmentos de grãos grossos a finos, produzidos pela desintegração das rochas, com tamanhos e formas variadas.

b) Sedimentos clásticos, finos a submicroscópicos, siltes e argilominerais, produtos da decomposição das rochas.

c) Sedimentos orgânicos, restos de plantas ou animais. Muitos calcários e dolomitos pertencem a esse grupo de rochas.

d) Sedimentos de precipitação química. Precipitação em águas oceânicas ou em rios, originando calcários, dolomitos, gesso e sais.

Dos sedimentos clásticos, os que apresentam maior interesse neste trabalho são os conglomerados e as brechas.

Conglomerado é uma rocha composta por seixos arredondados de vários tamanhos que são cementados, assemelhando-se a um concreto. Os seixos estão imersos numa matriz de fragmentos finos. Devido à grande distância de transporte e posterior deposição acontece uma mistura de seixos de várias cores e composição mineralógica, o que motiva 
o seu uso como rocha decorativa. A falta de resistência ao intemperismo aparece depois de alguns anos quando ocorre perda de polimento e aparecimento de depressões na superfície.

As brechas diferem dos conglomerados por apresentarem fragmentos angulosos, de composição mineralógica e cor uniforme muito utilizadas como rochas decorativas.

Dos vários tipos de rochas originadas pela precipitação química as que apresentam maior importância para a tese, são:

a) Calcário - composto principalmente por carbonato de cálcio. Impurezas de argila são menores que 5\%. Apresentam grande variação na sua composição mineralógica. Dão um bom polimento e são duráveis.

b) Calcário magnesiano - apresenta entre 5 e $40 \%$ de carbonato de magnésio.

c) Dolomita - Apresenta carbonato de cálcio, mas o teor de carbonato de magnésio situa-se acima de $40 \%$. São densas, duras e mais friáveis que os calcários.

d) Travertino - é uma variedade de calcário originário da precipitação em lagos e rios durante estações quentes e frias. Sua estrutura em camadas, porosidade e cores, que vão do creme ao marrom, conferem a essas rochas grande aceitação comercial. Os travertinos italianos são os mais conhecidos pela beleza das suas cores e textura fina.

e) Ônix - sua origem é semelhante à dos travertinos. É uma rocha translúcida com cristais de grãos finos. Tem uma grande variedade de cores desde branco, pastel, marfim, verde claro e marrom dourado, originando chapas translúcidas usadas em banheiros e pisos, dando um efeito semelhante a vidro de cor opala. Os mais famosos ônix são do México, Itália e Irã.

f) Calcário com carapaça - apresentam carapaças fósseis bem cementadas. Podem ser desdobrados em chapas, apresentando grande resistência mecânica e beleza muito apreciada. Os mais conhecidos são originários da Bélgica e dos Estados Unidos. 
g) Calcários coralígenos - apresentam se geralmente como uma colônia de corais brancos cementados por uma matriz cinza ou escura. São comuns na Flórida (E.U.A).

\subsubsection{Rochas metamórficas}

As que apresentam maior interesse são:

a) Gnaisse - semelhante ao granito, mostrando, porém, um arranjo paralelo dos grãos. A estrutura gnáissica apresenta uma maior resistência à compressão na direção perpendicular ao eixo de orientação dos grãos em comparação com a apresentada na direção paralela ao mesmo eixo. O corte da rocha é mais fácil na direção da clivagem das micas.

b) Xisto - é semelhante ao gnaisse, mas o bandeamento é menos espesso, havendo ausência de quartzo e feldspato, e aumento da presença de mica e hornblenda o que facilita a quebra da rocha sob ação de uma força de impacto.

c) Mármore - é uma das rochas mais conhecidas nas aplicações ornamentais. Basicamente é constituído de grãos de calcita e dolomita grossos ou finos, tendo colorações que vão desde branco a cinza, preto, cor de rosa, marrom ou verde. Inúmeros minerais acessórios conferem características decorativas variadas. Dentre esses minerais cita-se a mica verde, grafita e minerais esverdeados. Os mármores brancos maciços de grana fina são usados para monumentos. As variedades de grana grossa não são utilizadas devido a clivagem da calcita em três direções. São famosos os mármores gregos e italianos.

d) Serpentinito - essencialmente constituídos por serpentinita, um silicato de magnésio. Sua textura e cor verde lhe conferem características importantes para uso como rocha ornamental. Outra característica ornamental é a presença de vênulas brancas de calcita e dolomita. A resistência ao intemperismo da serpentinita permite seu uso interno ou externo nos edifícios. Sua baixa dureza, semelhante aos mármores, permite seu uso para fins ornamentais.

e) Quartzito - constituído por grãos de quartzo recristalizado, tendo como minerais acessórios calcita e mica. A rocha é muito dura, de cor branca ou 
amarela clara, podendo ter cores vermelha a amarela devido à presença de óxidos de ferro, esverdeados pela presença de mica, ou ainda raramente, como no Brasil, a presença de dumortierita, mineral azul, que lhe confere uma beleza incomparável.

Tabela 3.1 Principais tipos de rochas usadas como mármores e granitos.

\begin{tabular}{|c|c|c|c|c|}
\hline ROCHA & & INTRUSIVA & INTERMEDIÁRIA & EXTRUSIVA \\
\hline \multirow[t]{4}{*}{ ÍGNEA } & \multirow{2}{*}{$\begin{array}{l}\text { Cor Clara } \\
\text { (ácida) }\end{array}$} & Granito & 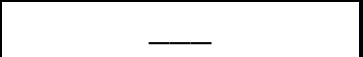 & Felsito \\
\hline & & Sienito & Pórfiro & 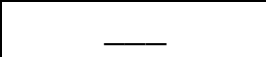 \\
\hline & \multirow{2}{*}{$\begin{array}{l}\text { Cor Escura } \\
\text { (básica) }\end{array}$} & Diorito & 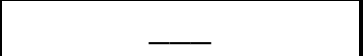 & Andesito \\
\hline & & Gabro & - & Basalto \\
\hline \multirow{4}{*}{ SEDIMENTAR } & & Grão Grosso & Grão Médio & Grão Fino \\
\hline & Clástica & $\begin{array}{c}\text { Conglomerado e } \\
\text { Brecha }\end{array}$ & - & - \\
\hline & Orgânica & $\begin{array}{c}\text { Calcário ou } \\
\text { dolomito com } \\
\text { carapaça } \\
\end{array}$ & $\begin{array}{c}\text { Carbonato cristalino } \\
\text { com ou sem } \\
\text { carapaça } \\
\end{array}$ & $\begin{array}{l}\text { Calcário } \\
\text { Dolomito }\end{array}$ \\
\hline & Evaporito & - & Carbonato cristalino & Carbonato \\
\hline \multirow[t]{5}{*}{ METAMÓRFICA } & & Grão Grosso & Grão Médio & Grão Fino \\
\hline & $\begin{array}{l}\text { De rochas } \\
\text { Ígneas } \\
\end{array}$ & Gnaisse & Gnaisse & - \\
\hline & \multirow[t]{3}{*}{$\begin{array}{l}\text { De rochas } \\
\text { Sedimentares }\end{array}$} & Gnaisse & Gnaisse & Mármore \\
\hline & & Mármore & Mármore & Quartzito \\
\hline & & 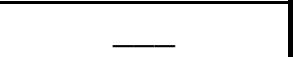 & Quartzito & Serpentinito \\
\hline
\end{tabular}




\subsection{Cor e Brilho dos Minerais}

Segundo, Wrinckler (1973) a Tabela 3.2 mostra as cores mais comuns dos minerais formadores das rochas ornamentais.

Tabela 3.2 Cor dos minerais mais comuns fornecedores dos mármores e Granitos

\begin{tabular}{|c|c|c|c|c|}
\hline Cor & Mineral & Rocha Ígnea & $\begin{array}{c}\text { Rocha } \\
\text { Sedimentar }\end{array}$ & $\begin{array}{c}\text { Rocha } \\
\text { Metamórfica }\end{array}$ \\
\hline Amarela & Limonita & & Calcário & \\
\hline \multirow[t]{4}{*}{ Azul } & $\begin{array}{l}\text { Dumortierita } \\
\text { (rara) }\end{array}$ & & & Quartzito \\
\hline & Sodalita (rara) & Sienito & & \\
\hline & $\begin{array}{l}\text { Labradorita } \\
\text { (rara) }\end{array}$ & Charnokito & & \\
\hline & Quartzo & & & Xisto \\
\hline \multirow[t]{5}{*}{ Branca } & Ortoclásico & Granito & & Gnaisse \\
\hline & Plagioclásio & Granito & & Gnaisse \\
\hline & Quartzo & Granito & & Gnaisse, quartzito \\
\hline & Muscovita & & & $\begin{array}{l}\text { Mármore, xisto } \\
\text { Quartzito }\end{array}$ \\
\hline & Cálcita & & Calcário & Mármore \\
\hline \multirow[t]{4}{*}{ Cinza } & Plagioclásio & Diorito, Gabro & & Gnaisse \\
\hline & Quartzo & Granito & & Gnaisse, quartzito \\
\hline & Grafita & & & Mármore, gnaisse \\
\hline & Substância & & Calcário & \\
\hline
\end{tabular}

\begin{tabular}{|c|c|c|c|c|}
\hline \multirow{3}{*}{$\begin{array}{l}\text { Dourada } \\
\text { Marrom }\end{array}$} & \multicolumn{4}{|l|}{ Organıca } \\
\hline & Sericita & \multirow{2}{*}{\multicolumn{2}{|c|}{ Granito }} & Mármore \\
\hline & Hornblenda & & & Gnaisse, xisto \\
\hline & Biotita & \multicolumn{2}{|l|}{ Granito } & $\begin{array}{l}\text { Gnaisse, xisto e } \\
\text { mármore }\end{array}$ \\
\hline \multirow[t]{4}{*}{ Preta } & Hornblenda & \multicolumn{2}{|c|}{ Granito, gabro, diorito } & Gnaisse \\
\hline & Biotita & \multicolumn{2}{|c|}{ Granito, gabro, diorito } & $\begin{array}{l}\text { Gnaisse, } \\
\text { mármore. }\end{array}$ \\
\hline & \multicolumn{3}{|l|}{ Grafita } & $\begin{array}{l}\text { Mármore, gnaisse } \\
\text { e xisto }\end{array}$ \\
\hline & \multicolumn{3}{|c|}{ Substância Orgânica } & \\
\hline \multirow[t]{4}{*}{ Verde } & Hornblenda & \multirow{2}{*}{\multicolumn{2}{|c|}{ Granito }} & Gnaisse, xisto \\
\hline & $\begin{array}{l}\text { Clorita, } \\
\text { sericita. }\end{array}$ & & & $\begin{array}{l}\text { Gnaisse, xisto e } \\
\text { mármore }\end{array}$ \\
\hline & \multicolumn{3}{|c|}{ Glauconita } & \\
\hline & Hidróxido d & rro & Calcário & Quartzito \\
\hline \multirow{2}{*}{$\begin{array}{l}\text { Vermelha } \\
\text { rosa }\end{array}$} & Ortoclásio & \multirow{2}{*}{\multicolumn{2}{|c|}{ Granito }} & Gnaisse \\
\hline & $\begin{array}{l}\text { Hematita } \\
\text { Cálcita }\end{array}$ & & & $\begin{array}{l}\text { Gnaisse, mármore } \\
\text { Mármore }\end{array}$ \\
\hline
\end{tabular}




\subsubsection{Cor das rochas ígneas}

A rocha ígnea se cristaliza a partir de um magma quente, em cristais grossos ou finos dependendo da velocidade de resfriamento. Os minerais mais comuns nessas rochas e que determinam suas cores, são:

a) Ortoclásio em granitos e sienitos, conferindo a eles cores que vão de um vermelho carne a rosa até branco. A presença desse mineral nas rochas entre 50 a $75 \%$ determina sua cor característica. A cor avermelhada dos ortoclásios é devida a presença de óxido férrico.

b) Nos dioritos e gabros a presença de plagioclásio confere a cor branca, os feldspatos sódicos a cor cinza e os feldspatos cálcicos a cor preta. A quantidade de plagioclásio presente nos gabros e dioritos é de aproximadamente $50 \%$. A presença de ferro férrico e ferroso resulta em cores cinza a preta nos plagioclásios. A labradorita origina rochas escuras e, por ser iridescente, aparece em cores claras e até pouco azuladas.

c) Hornblenda e augita apresentam cores que vão do verde ao preto. A oxidação e também a hidratação desses minerais que contem ferro férrico e ferroso, durante o processo de intemperismo transformam suas cores em marrom e marrom-ocre.

d) Biotita apresenta cor marrom a preta como resultado da presença do ferro férrico e ferroso e é bastante susceptível ao intemperismo. O seu intemperismo é bastante notável por aparecer nas bordas do grão uma cor marrom avermelhada.

e) Muscovita se apresenta sem coloração ou com cor cinza prateada,sendo, muito estável com relação à cor.

f) Quartzo nos granitos se apresenta com cor branca ou cinza pérola e ocasionalmente azulado devido à presença de óxido de titânio. 
g) Pirita aparece em todas as rochas ígneas. Tem uma lixiviação e oxidação lenta, resultando em cores do marrom a marrom ocre.

\subsubsection{Cor das rochas sedimentares}

Para melhor compreensão da coloração das rochas sedimentares é comum dividi-las em 2 grupos:

a) de origem clástica

b) de origem química e orgânica

Ferro é o mais comum e mais forte pigmento das rochas sedimentares. Ele pode ser precipitado nas bacias de sedimentação ou originário da decomposição de organismos. Muitos aparecem durante o processo de litificação e outros devido a processos geológicos secundários.

O ferro férrico aparece como hematita vermelha e a goetita nas cores marrom avermelhada e marrom ocre. Brechas e conglomerados são geralmente cementados por cemento marrom avermelhado. Calcários avermelhados são raros.

O ferro ferroso aparece como pirita amarela ou na forma de carbonato (siderita) de cor cinza ou branca.

Os pigmentos de ferro nas rochas sedimentares são instáveis se expostos à luz ou ao intemperismo, ocasionando a degradação das cores das rochas sedimentares.

Carbono na forma de substâncias orgânicas aparece disseminado, como:

a) hidrocarbonetos solúveis em solventes.

b) asfalto sólido e semi-sólido, solúveis em bissulfeto de carbono.

c) querogênio, insolúvel em solvente sendo o componente muito comum em rochas carbonáticas.

As cores que aparecem vão do cinza ao preto. 


\subsubsection{Cor das rochas metamórficas}

Gnaisse, xisto, quartzito e mármore cristalino são os mármores e granitos mais utilizados. Gnaisse e xisto são compostos por minerais presentes nas rochas ígneas e sedimentares, cujos pigmentos se mantêm estáveis após o metamorfismo. Assim, as cores são parecidas com as cores das rochas que lhe deram origem. Alguns pigmentos novos aparecem devido à presença de sericita, clorita e grafita.

A sericita é uma variedade de grãos muito finos de muscovita de cores prateadas a esverdeadas que aparecem com freqüência em mármores e xistos. Clorita aparece com cores verdes. Grafita na forma de escamas nas cores cinza e negra prateada aparece em muitos mármores e xistos. Em todos os minerais, exceto a grafita os pigmentos são estáveis.

Calcários sedimentares e conglomerados apresentam grande variação de cores durante o metamorfismo. Freqüentemente os minerais coloridos aparecem como concentrados em faixas onduladas de cores verdes ou pretas.

Os calcários sedimentares são metamorfizados em mármores onde o carbono na forma de grafita concentra-se em faixas onduladas ou nas juntas.

Tons quentes de cores creme, ocre, preta, presentes nas rochas sedimentares originais são transformados em cores brancas frias com cores verdes, prata, amarela ou verde escura.

O hidrocarboneto presente nos calcários, durante o metamorfismo, pode dar origem a um mármore branco com grafita. Mármores rosa e vermelho são mais raros, porém quartzitos cor de rosa e vermelho são mais comuns devido à hematita vermelha. 


\subsubsection{Brilho}

Segundo Pearl (1955); Leinz (1971); Kuzin e Egarov (1979), o brilho dos minerais e das rochas é a propriedade mais fácil de ser observada. Ele não pode ser confundido com lustro por ser uma propriedade intrínseca dos minerais, enquanto que o lustro se refere ao acabamento superficial dado aos minerais e rochas para permitir que a luz seja refletida com maior intensidade. O brilho é o resultado dos fenômenos de refração e reflexão da luz nas faces dos cristais, nos planos de clivagem e nas fraturas. Quanto maior for a intensidade da luz incidente no mineral mais evidente será a observação do seu brilho.

Se o mineral for opaco apresentará brilho metálico como a pirita e a galena. Se for transparente apresentará brilho não metálico, com uma variedade de tipos, como:

- Brilho adamantino, que se assemelha ao brilho do diamante. A esfalerita apresenta esse tipo de brilho.

- Brilho vítreo, semelhante ao brilho do quartzo. A maioria dos minerais não metálicos apresenta esse brilho.

- Brilho leitoso, como o quartzo e algumas rochas constituídas por agregados de minerais de grãos muito finos.

- Brilho sedoso, apresentado pelos minerais fibrosos (amianto) e os constituídos por camadas finas e sucessivas (micas, muscovita e flogopita) que provocam a reflexão da luz entre as fibras e as camadas.

- Brilho resinoso, apresentado pela pitchiblenda.

- Brilho oleoso, característico do enxofre e da nefelina.

Como o brilho é facilmente perceptível, tem importância fundamental no aspecto dos mármores e granitos. Exemplo importante a ser citado é o caso dos mármores brancos de Cachoeiro de Itapemirim, Estado do Espírito Santo, de alto metamorfismo com cristais grandes, com brilho vítreo e o mármore branco de Carrara, Itália, de baixo metamorfismo, com microcristais, com brilho leitoso, sendo este último o preferido. 


\subsection{Classificação}

As rochas ornamentais podem ser reunidas em 10 grandes grupos de desenhos que podem ser encontrados na natureza. Porém, esses grupos podem apresentar variações na cor e no desenho que devem ser consideradas.

\subsubsection{Segundo sua gênese}

As setas no canto inferior esquerdo da Tabela 3.3 indicam a ação crescente do metamorfismo (altas pressões e temperatura), transformando os diversos tipos de rochas.

Tabela 3.3 Classificação Tecnológica das Rochas Ornamentais.

\begin{tabular}{|c|c|c|c|c|c|}
\hline \multirow{2}{*}{ 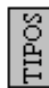 } & \multirow{2}{*}{ FORMAÇÃO } & \multicolumn{2}{|c|}{ SILICOSAS } & \multirow{2}{*}{ CALCÁRIAS } & \multirow{2}{*}{ ARGILOSAS } \\
\hline & & quartziferas & feldspáticas & & \\
\hline \multirow{2}{*}{ 学 } & DE PROFUHDIDADE & granitos & $\begin{array}{l}\text { sienitos } \\
\text { dioritos } \\
\text { gabros }\end{array}$ & & \\
\hline & EFUSIVAS & riolitos & $\begin{array}{l}\text { traquitos } \\
\text { fonolitos } \\
\text { andesitos } \\
\text { diabásios } \\
\text { basaltos }\end{array}$ & & \\
\hline \multirow{3}{*}{ 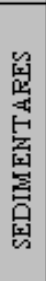 } & CLÁSTICAS & arenitos & oravoloos & $\begin{array}{c}\text { brechas } \\
\text { conglomerados }\end{array}$ & \\
\hline & ORGÂHICAS & $\longrightarrow$ & $\longrightarrow$ & $\begin{array}{l}\text { tufgs } \\
\text { tipos diversos }\end{array}$ & $\longrightarrow$ \\
\hline & QUÍMICAS & & & $\begin{array}{l}\text { alabastros } \\
\text { travertinos } \\
\text { estalactites } \\
\text { estalagmites } \\
\text { tipos diversos }\end{array}$ & \\
\hline \multirow{4}{*}{ 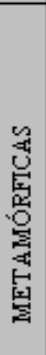 } & \multirow{4}{*}{$\begin{array}{r}\text { argilas } \\
\text { xistos argilosos } \\
\text { ARDÓsIas } \\
\text { xistos cristalinos } \\
\text { arentos } \\
\text { QUARTZITOS }\end{array}$} & gnaisses & & & \\
\hline & & micaxistos & & & ardósias \\
\hline & & quartzitos & & 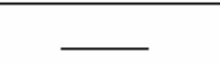 & \\
\hline & & & & mármores & - \\
\hline
\end{tabular}

Fonte: Cavalcanti (1951). 


\subsubsection{Segundo seus usos}

Tabela 3.4 Classificação Tecnológica das Rochas Ornamentais segundo seus usos

\begin{tabular}{|c|c|c|}
\hline \multirow[t]{5}{*}{ 1) } & MÁRMORE & $\begin{array}{l}\text { Rocha cristalina, compacta, lustrável constituída principalmente por } \\
\text { minerais de dureza Mohs da ordem de } 3 \text { a } 4 \text { (tais como calcita, } \\
\text { dolomita e serpentina). }\end{array}$ \\
\hline & & A esta categoria pertencem: \\
\hline & & $\begin{array}{l}\text { Mármore propriamente dito - Calcário Metamorfizado, } \\
\text { Recristalizado. } \\
\text { Calcário, Dolomita e Brecha Calcária lustrável. }\end{array}$ \\
\hline & c) & Alabastro (Gipsita branca, fina, translúcida). \\
\hline & & $\begin{array}{l}\text { Serpentinito (constituído por Serpentina, resultado da alteração de } \\
\text { Anfibólio e Piroxênio). }\end{array}$ \\
\hline \multirow[t]{4}{*}{ 2) } & GRANITO & $\begin{array}{l}\text { Rocha fanero-cristalina, compacta, lustrável, constituída } \\
\text { principalmente por minerais de dureza Mohs entre } 6 \text { e } 7 \text { (quartzo, } \\
\text { feldspato). }\end{array}$ \\
\hline & & A esta categoria pertencem: \\
\hline & $\begin{array}{l}\text { a) } \\
\text { b) } \\
\text { c) }\end{array}$ & $\begin{array}{l}\text { Granito propriamente dito - rocha magmática intrusiva acida } \\
\text { fanero-cristalina, constituída por quartzo, feldspato e mica. } \\
\text { Outras rochas magmáticas intrusivas (diorito, granodiorito, sienito, } \\
\text { gabro, etc.). } \\
\text { Rochas magmáticas efusivas }\end{array}$ \\
\hline & d) & Rochas metamórficas \\
\hline 3) & TRAVERTINO & $\begin{array}{l}\text { Rocha calcária sedimentar, tendo algumas variedades lustráveis, } \\
\text { dureza entre } 3 \text { e } 4 \text {, tendo estrutura com vesícula preenchida ou não. }\end{array}$ \\
\hline & PEDRA & $\begin{array}{l}\text { Rocha geralmente não lustrável. É uma categoria com composição } \\
\text { mineralógica muito variável. }\end{array}$ \\
\hline & & A esta categoria pertencem dois grupos: \\
\hline & a) & Rocha pouco resistente e/ou pouco compacta \\
\hline & b) & Rocha resistente e/ou compacta \\
\hline
\end{tabular}

Fonte: Corbella (1998) 


\subsubsection{Segundo suas estruturas}

Travis (1955) comenta que o reconhecimento dos materiais lapídeos não é simples, principalmente para as pessoas que não tenham conhecimentos de geologia. Não é também o objetivo dessas pessoas dominar técnicas laboratoriais ou ter outros conhecimentos para obter essas informações.

Vianello (1995) propôs uma classificação das rochas ornamentais baseada na sua estrutura ou desenho, fazendo uma consideração inicial entre estrutura e textura (termos científicos que muitos autores adotam como sinônimos), cuja discussão nada acrescenta aos nossos objetivos. Além de "estrutura”, usa-se, no Brasil, o termo "padrão".

Segundo Vianello, o termo estrutura de uma rocha significa a relação espacial entre um mineral, sua forma, seu intercrescimento com os outros minerais, sua cor, enfim, tudo que esteja ligado ao seu aspecto, que se torna mais evidente no material polido.

O termo padrão é utilizado de uma forma geral pelos que militam no setor lapídeo, onde, dada a experiência dessas pessoas, as rochas são identificáveis a olho nu, analisando sua estrutura e principalmente a cor dos minerais.

Toda a classificação de Vianello é baseada em conceitos científicos, onde foram definidos 10 grupos de estruturas e suas respectivas rochas como mostra a Tabela 3.5.

As Fotos 3.1 a 3.9 foram extraídas de Vianello (1995).A Foto 3.10 é de acervo particular. As Figuras 3.2 a 3.4 foram extraídas de Tyrrell (1956). 
Tabela 3.5 Classificação das Rochas Ornamentais segundo suas estruturas.

\begin{tabular}{|c|c|c|}
\hline & Grupo & Rochas que apresentam essas características \\
\hline 1 & Compacta & $\begin{array}{l}\text { Calcário - Mármore puro - Mármore colorido } \\
\text { Quartzito - Mármore sacaróide }\end{array}$ \\
\hline 2 & Nodular & Calcário com cemento de carbonato de cálcio e argila \\
\hline 3 & Fossilífera & Calcário fossilífero \\
\hline 4 & Porosa & Calcário mole - Rocha piroclástica \\
\hline 5 & Bandeada ou Estratificada & $\begin{array}{l}\text { Mármore Listado ou Bandeado de Concreção - } \\
\text { Estratificada }\end{array}$ \\
\hline 6 & Clástica & $\begin{array}{l}\text { Conglomerado - Arenito - Mármore brecha - } \\
\text { Oficalcita }\end{array}$ \\
\hline 7 & Xistosa & $\begin{array}{l}\text { Gnaisse, Xisto (Filito e Micaxisto) e Ardósia - } \\
\text { Serpentinito. }\end{array}$ \\
\hline 8 & Granular (Olocristalina) & $\begin{array}{l}\text { Ácida (Granito claro) - Intermediária, } \\
\text { medianamente silicatada - Básica e Ultrabásica } \\
\text { (Granito escuro). }\end{array}$ \\
\hline 9 & Porfirítica & Ácida - Intermediária - Básica \\
\hline 10 & Fluidal & Migmatito ou Granito Veiado \\
\hline
\end{tabular}




\section{$\underline{\text { Estrutura Compacta }}$}

É a estrutura caracterizada pela uniformidade do grão, geralmente muito fina, que dá ao material um aspecto maciço e uniforme. É uma característica dos materiais contendo

carbonato de cálcio. É a estrutura típica de rochas sedimentares (calcário compactado) e também das rochas metamórficas (mármore puro, mármore colorido e quartzito). Nos materiais de origem metamórfica, geralmente a estrutura do tipo cristalino, pode dar ao material um aspecto típico, "frio". Se os cristais são maiores, visíveis a olho nu, se fala em estrutura sacaróide.

Calcário compacto - tem geralmente grãos muito finos a ponto de não permitir individualizar um simples cristal. Apresentam coloração clara (branca, avelã, etc.) com eventuais fósseis e estrutura sedimentar. Quando rico em substância carbonosa ou betuminosa apresenta coloração escura, dando calcários negros (até negro absoluto).

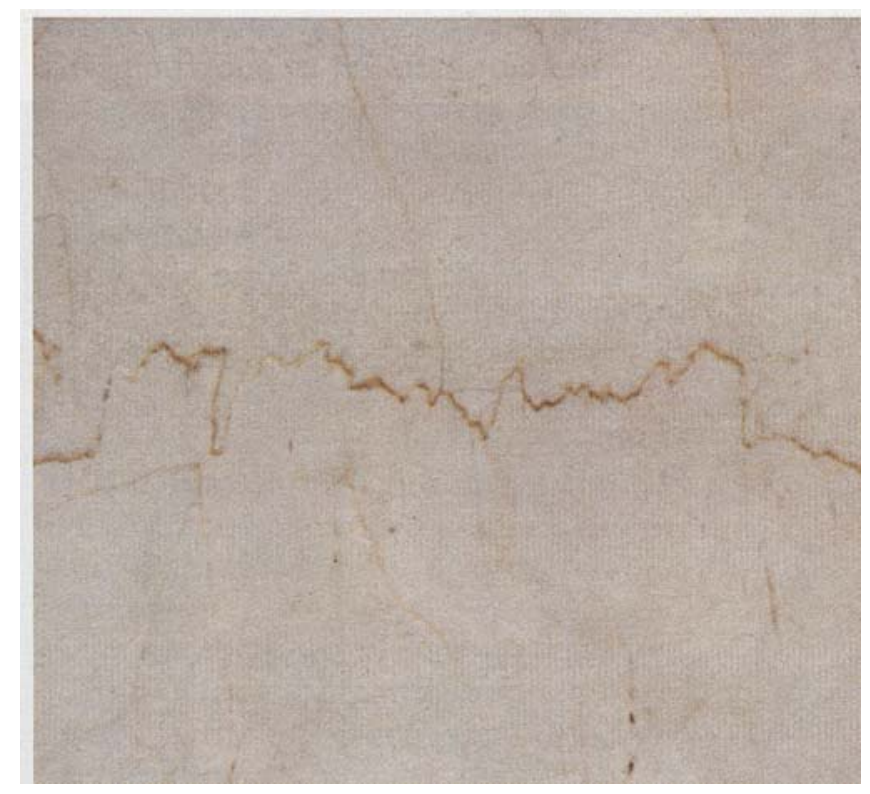

Foto 3.1 Calcário compacto.

Mármore puro e mármore veiado - são constituídos de carbonato de cálcio, recristalizado no processo metamórfico. Têm coloração branca. Podem apresentar veios ou áreas e pontos de coloração. Recebem o nome de estatuário quando apresentam coloração, grãos de certo tamanho e trabalhabilidade. 
Mármore colorido e quartzito - apresentam pigmentação difusa que lhe dá a sua cor característica. Existem mármores rosa, azul celeste, vermelho, etc. O que difere um mármore do quartzito é a composição química, sendo o primeiro constituído por carbonato de cálcio e o segundo por sílica. Uma forma de diferenciar o mármore do quartzito é o teste da sua dureza pelo uso de canivete: se a lâmina riscar a rocha, trata-se de um mármore, se não riscar ele é um quartzito.

Mármore sacaróide - constituído por minerais de carbonato de cálcio da mesma dimensão e identificáveis a olho nu. A sua dimensão se deve à ação prolongada de alto grau de metamorfismo. Apresenta semelhança com açúcar.

\section{$\underline{\text { Estrutura nodular }}$}

Tem aspecto não homogêneo, devido à presença maciça de nódulos compactos imersos numa matriz cementante. Geralmente os nódulos mais resistentes são constituídos por carbonato de cálcio, enquanto que a matriz é constituída por carbonato de cálcio e argila. É uma estrutura típica de rocha sedimentar. A coloração desse material é muito variável, indo do vermelho ao amarelo e do branco ao verde e etc. O material apresenta pouca trabalhabilidade.

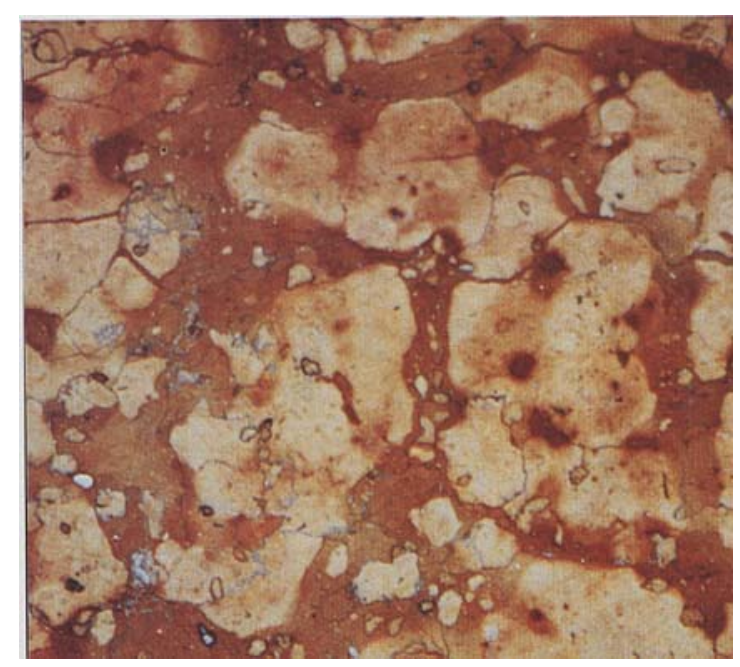

Foto 3.2 Calcário nodular. 


\section{Estrutura fossilífera}

Típica de rochas sedimentares contendo restos fósseis (lamelibrânquios, foraminíferos, gasterópodos, etc.). Os fósseis tem tamanho e forma as mais diversas. A cor também é bastante variável.

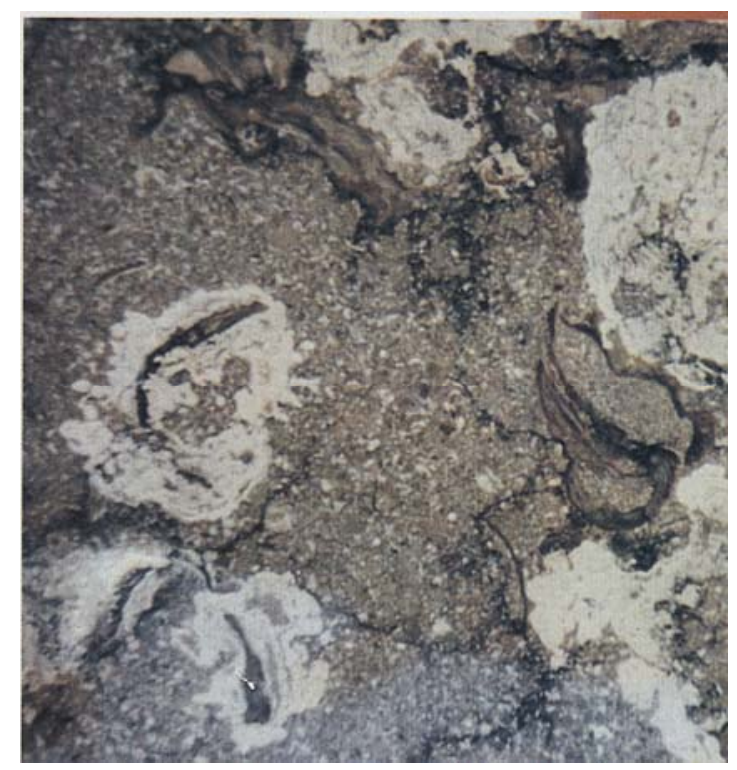

Foto 3.3 Calcário fossilífero.

\section{Estrutura porosa}

É característica dos materiais pouco compactos, apresentando cavidades difusas de diversas dimensões, que constituem a porosidade da rocha. Esses materiais são pouco resistentes, pouco duráveis e não lustráveis. Podem ter origem diversa, como rocha sedimentar, em ambiente marinho, ou como rocha piroclástica, resultante de deposição de cinzas em zonas vulcânicas. Esses materiais são semelhantes a ponto de se chamar de tufo (material de origem vulcânica) o calcário pouco competente. A coloração é variável, sendo mais comuns as cores claras (amarela, cinza, branca, etc.). Os grãos têm tamanho variável, apresentando fragmentos ou fósseis. Podem ser considerados também como tendo estrutura tipo clástica. 


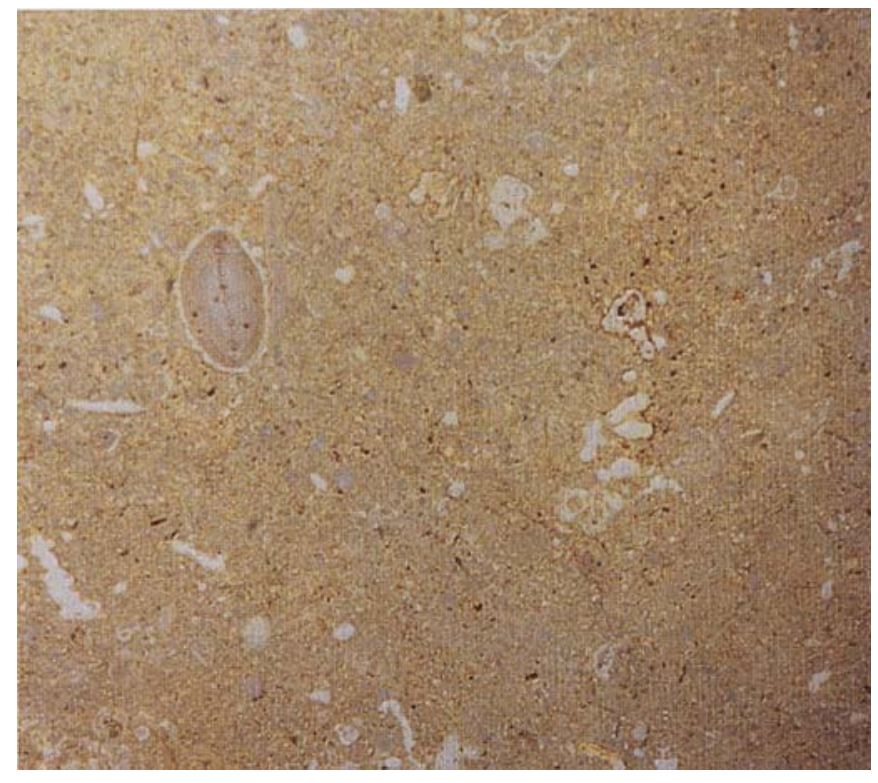

Foto 3.4 Calcário poroso.

\section{Estrutura bandeada ou estratificada}

São materiais que apresentam um andamento da coloração irregular, de uma forma mais ou menos linear, e a mancha com desenho particular devido a aspectos genéticos. A dificuldade de se caracterizar esteticamente este grupo é que alguns desses materiais (em particular, o alabastro) apresentam estrutura muito variável, seja do tipo linear, seja do tipo fechado, sub-circular, típica do fenômeno de concreção. Tanto o travertino, quanto o alabastro se cortam no plano do segundo, apresentando uma estrutura estratificada, típica da rocha sedimentar da qual fazem parte. Assim foram reunidos os dois grupos, o de estrutura bandeada e o de estrutura estratificada. O mármore metamórfico variegado apresenta muitos desenhos, o que dificulta sua classificação.

Mármore listado ou bandeado - são rochas metamórficas, caracterizadas por uma massa cristalina homogênea, de grana fina, com coloração variável, cortada por uma lista 
colorida, sub-paralela ou de andamento curvilíneo, mais ou menos irregular. Alguns mármores podem apresentar em vez de lista, motivos cromáticos ou manchas.

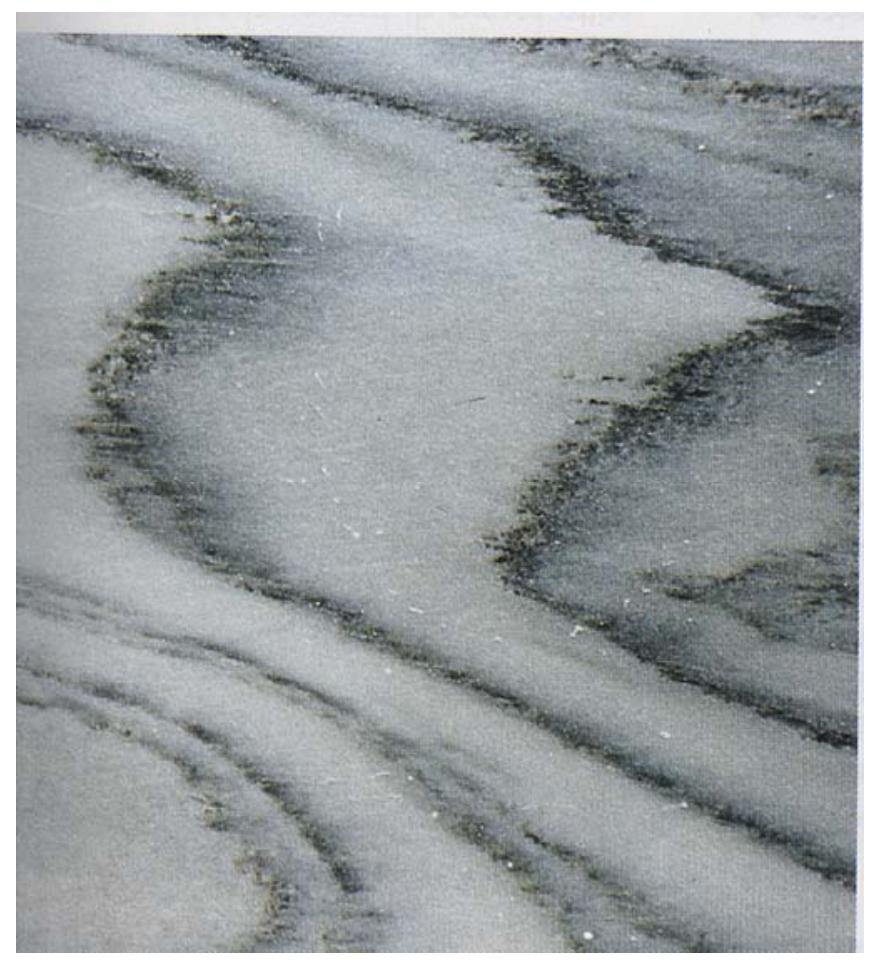

Foto 3.5 Calcário bandeado.

Material de concreção - apresenta estrutura bandeada, com característica de alguma rocha sedimentar, com concreção, que é formada em ambiente continental de água doce. Apresenta banda, com forma irregular, alongada, muitas vezes ovalada. A grana é fina e compacta, sendo em alguns casos reconhecíveis os cristais, como ocorre na estalactite. Este material se distingue do de origem metamórfica, porque não apresentam uma pasta de fundo sobre a qual se tem a banda, mas estes se sucedem uns aos outros de forma sedimentar. A sua disposição tende a refletir a forma do estrato precedente. Sua coloração é muito variável, indo do claro (branco, amarelo, etc.) a avelã, verde até rosado. A característica do alabastro calcário é a alternância cromática entre uma faixa e outra e de não apresentar cavidade interna, ao contrário do travertino. Fazem parte desse grupo o alabastro calcário, o ônix, alguns tipos de diásporos, travertinos e a estalactite. 


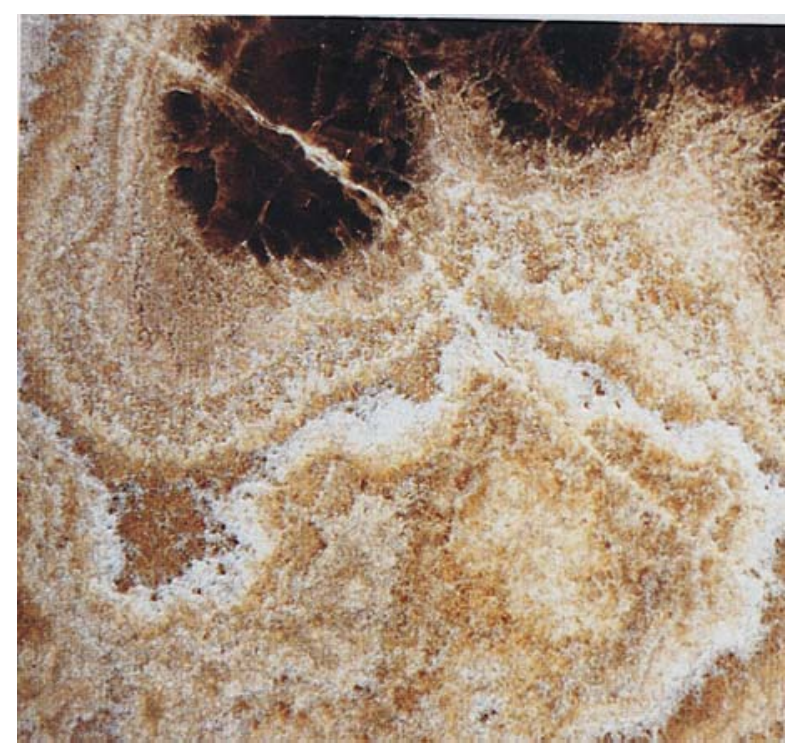

Foto 3.6 Mármore ônix.

Material com estrutura de estrato - muito semelhante à estrutura bandeada, típica de muitas rochas sedimentares, que se formam pelo acúmulo de material no tempo, sobretudo em ambiente marinho. Esse tipo de estrutura só é visível quando o bloco é cortado no plano do segundo que é ortogonal à estratificação. Quando o bloco é cortado no plano da corrida, não é possível ver a estratificação. 


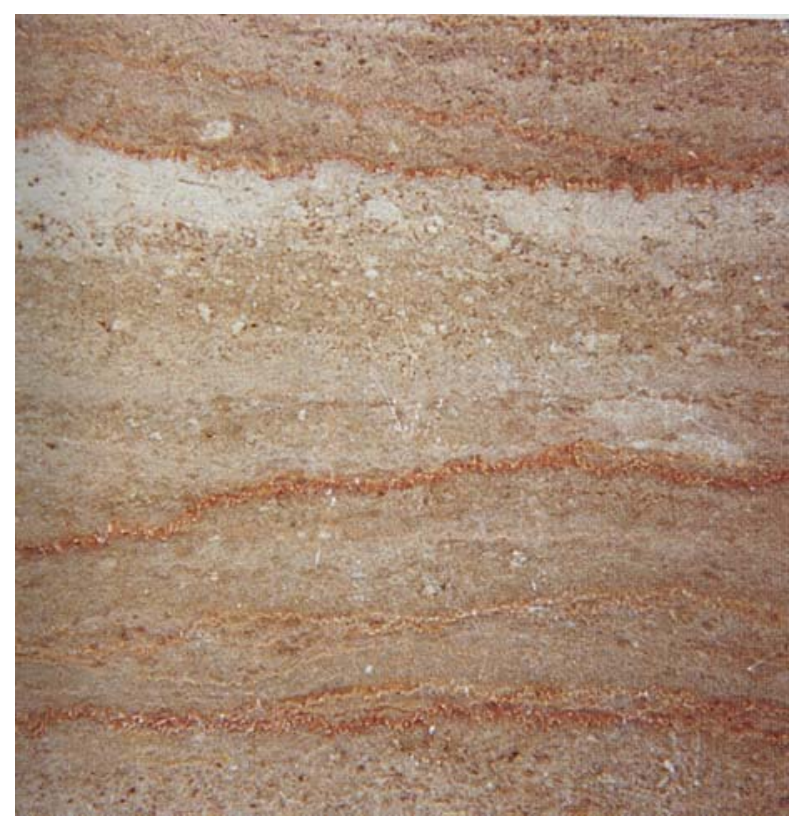

Foto 3.7 Mármore estratificado.

\section{$\underline{\text { Estrutura clástica }}$}

O termo clástico significa a ação de romper a rocha em fragmentos e ao mesmo tempo transportar esses fragmentos.

Refere-se à estrutura que apresenta o fragmento bem visível, seja de pequena ou de grande dimensão. Sua origem pode ser sedimentar ou metamórfica. A rocha clástica de origem sedimentar se divide, baseada no tamanho do fragmento, em conglomerado, arenito e siltito (este último de grãos finos, que não se presta como rocha ornamental e não será discutido, na presente tese). $O$ conglomerado apresenta fragmentos arredondados, de grandes dimensões e é cementado. Pode-se chamar de brecha quando o fragmento tem forma irregular. A coloração é muito variável. O arenito pode ser considerado areia cementada, de granulometria arredondada, não sendo muito resistente. O mármore brecha de origem metamórfica é de origem tectônica, formado em falhas geológicas. 


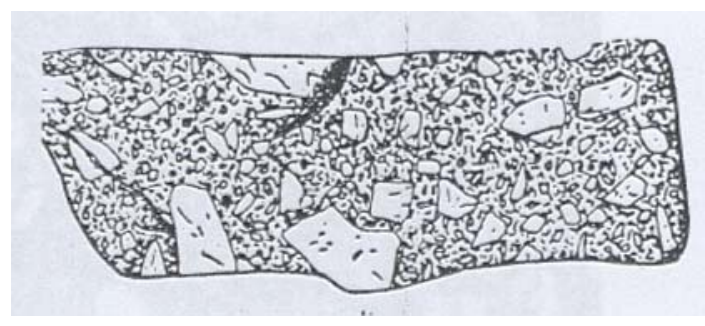

Fig. 3.2 Brecha calcária.

A oficalcita são rochas metamórficas originadas de serpentinitos que da mesma forma que a anterior sofreu uma posterior cementação (é conhecida no setor como mármore verde), apresentando veios de coloração verde clara a branca.

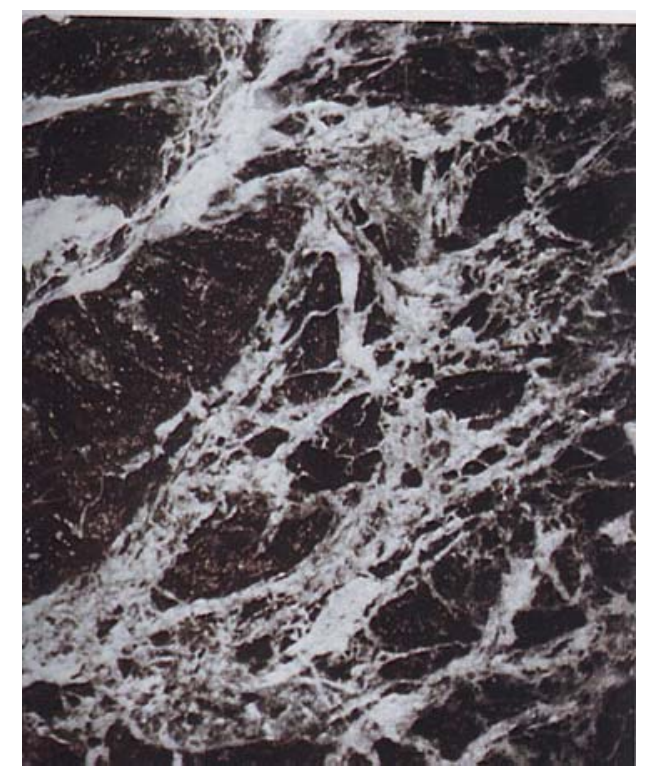

Foto 3.8 Oficalcita.

\section{$\underline{\text { Estrutura xistosa }}$}

É característica de algumas rochas metamórficas, especialmente aquelas que contêm minerais lamelares como a mica. No processo, esse mineral se orienta paralelamente à tensão gerando o plano de xistosidade (filito e xisto) e também de direção preferencial 
como o gnaisse. No filito se forma uma massa fibrosa, compacta. O gnaisse tem composição similar ao granito, porém há uma alternância de cores claras e escuras e andamento mais ou menos paralelo. Quando o feldspato de potássio está na forma de cristais grandes ou em nódulos, a rocha vem adjetivada como ghiandonata ou occhiadina. Esta variedade é um termo de passagem entre gnaisse e granito que as vezes é de difícil determinação. Filito, micaxisto e ardósia têm estrutura compacta de grana fina com aspecto acetinado. O serpentinito, dificilmente lustrável, tem aspecto fibroso. Particularmente, quando não são lustráveis, os serpentinitos passam a ter coloração verde escura.

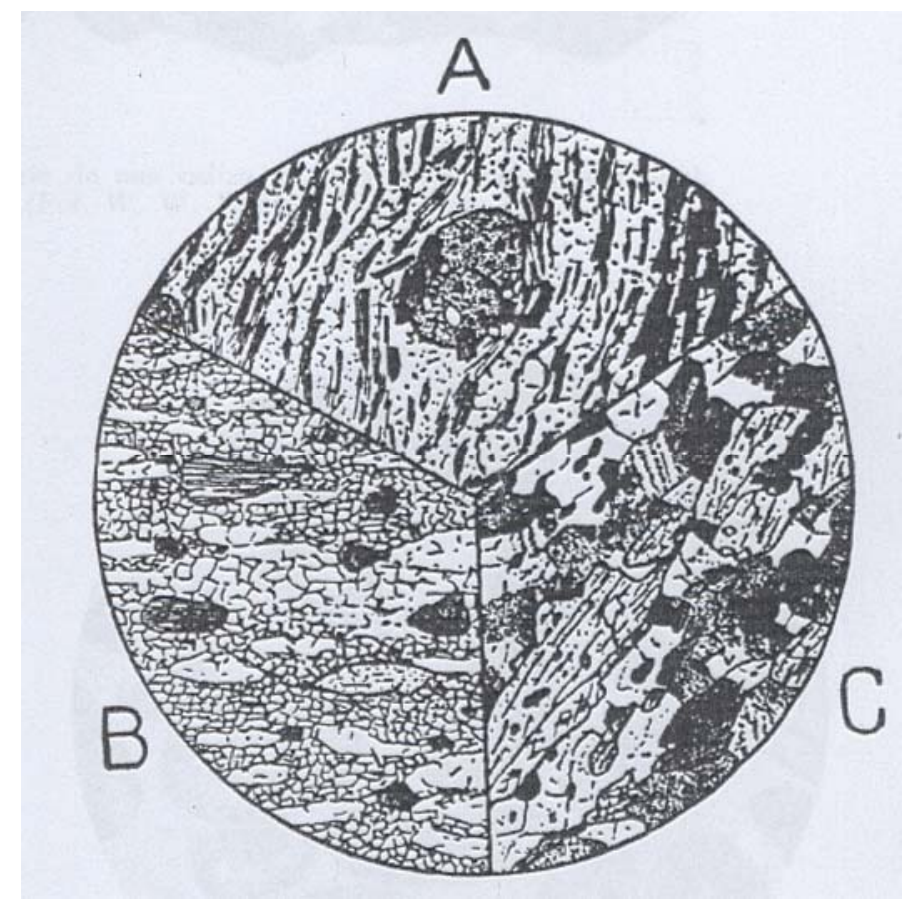

Fig.3.3 Tipos de Estruturas
A. Estrutura xistosa.
B. Estrutura granular.
C. Estrutura gnaissica. 


\section{Estrutura granular (olocristalina)}

É típica da rocha magmática intrusiva. Outros autores, como Tyrrell (1956); Williams et al. (1976), dão o nome de estrutura granitóide. Todos os minerais são cristalizados e reconhecidos macroscopicamente. O primeiro a se cristalizar apresenta hábito próprio, os outros minerais assumem formas diversas, sempre granulares, formando uma espécie de mosaico. Desta maneira a rocha magmática intrusiva poderá ser subdividida em: rocha ácida (granito), rocha meiosilicatada (diorito), básica e ultrabásica (gabro). As cores vão de claro para a ácida, ao escuro para básica. Entende-se por clara a rocha rica em minerais claros, como o quartzo, o plagioclásio e o feldspato. Este último, mesmo sendo branco, pode se apresentar com cores que vão do cinza, ao rosa e ao vermelho intenso.

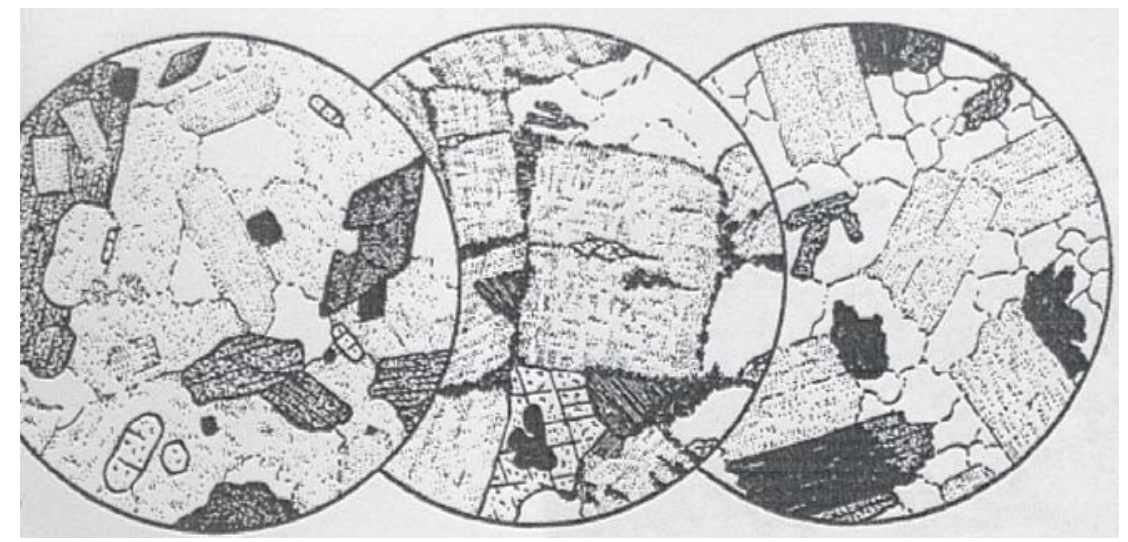

Fig.3.4 Estrutura granítica. 


\section{Estrutura porfirítica}

Característica da rocha magmática efusiva. Numa pasta de fundo microcristalina ou vitrosa, estão dispersos cristais (fenocristais), facilmente individualizados, cristalizados nos seus hábitos específicos. Do mesmo modo é dividida em ácida, meio silicatada e básica. Quanto à coloração, são válidas as mesmas considerações feitas para estrutura granular.

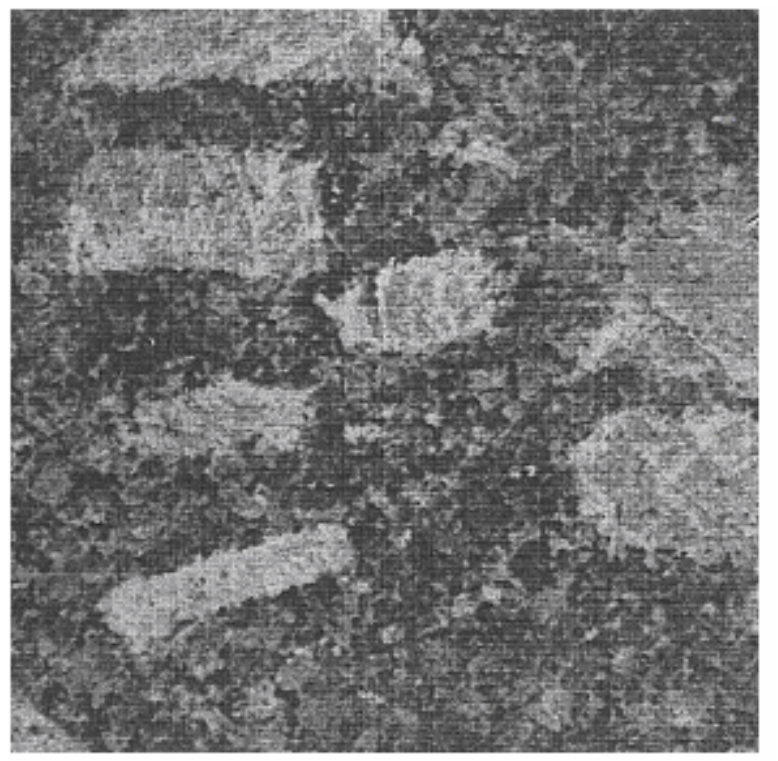

Foto 3.9 Estrutura porfirítica.

\section{$\underline{\text { Estrutura Fluidal }}$}

É característica de um tipo de rocha, o migmatito, que se forma no contacto entre e uma rocha metamórfica e o granito que se introduz no seu interior, provocando uma fusão parcial, criando um movimento no material passando do estado sólido ao estado plástico, que se conserva até a recristalização. A coloração é muito variável e intensa, com minerais claros e escuros separados, formando faixas cromáticas distintas. Este aspecto "movimentado” pode-se notar também em rochas sedimentares como os arenitos e rochas magmáticas efusivas, devido ao derramamento do magma, em fase de resfriamento na rampa do vulcão. 


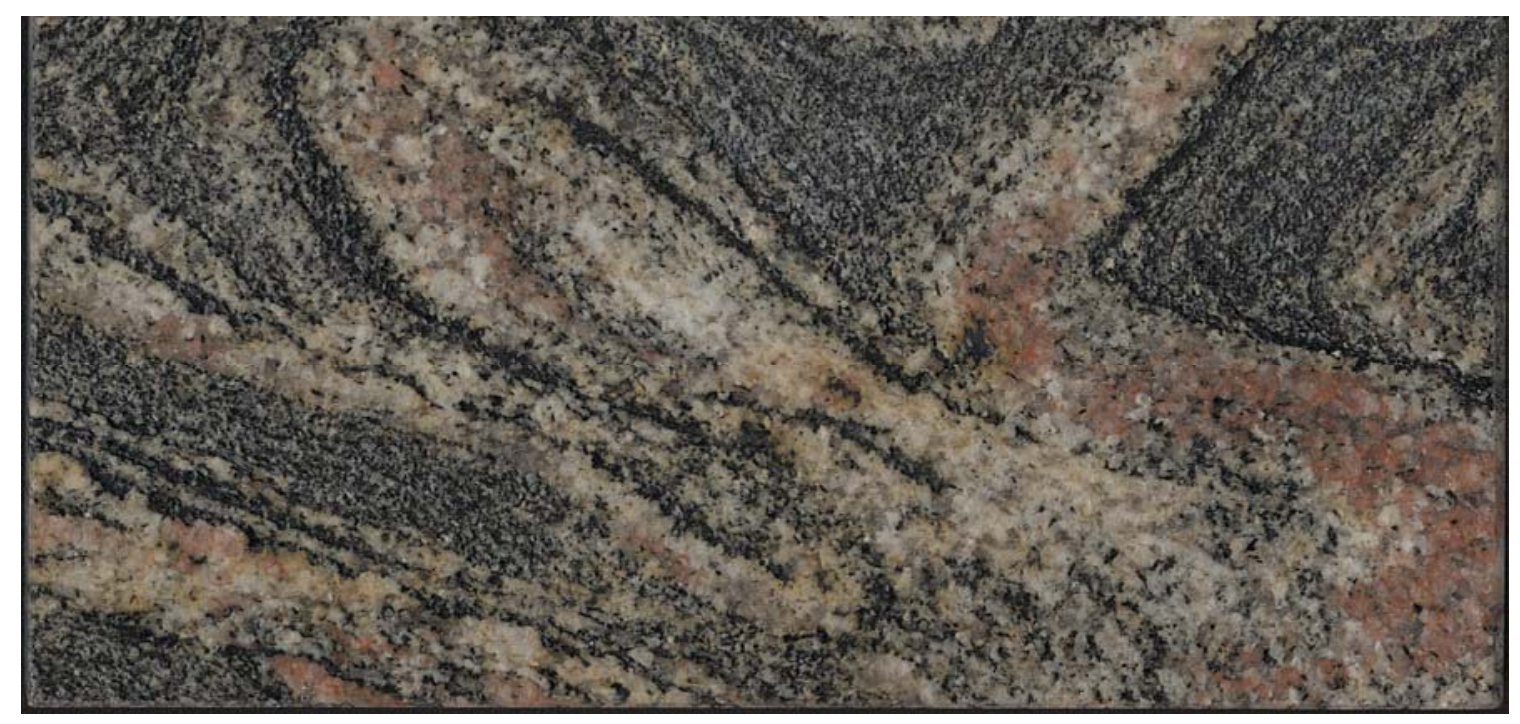

Foto 3.10 Estrutura fluidal.

\subsubsection{Classificação comercial pelas cores}

A Cor das rochas ornamentais é de fundamental importância do ponto de vista estético. Ela deriva do conteúdo de óxidos ou de substâncias orgânicas presentes na rocha, ou da sua composição mineralógica. De modo particular a cor rosa e todas as suas graduações até o vermelho vivo são causadas por hematita microcristalina, finamente difusa na rocha ou nos minerais constituintes. A coloração vermelho vinhático e violáceo é devida à presença de óxido de manganês. A cor amarela é devido à presença de óxido de ferro (limonita), que em elevada concentração pode gerar cor marrom escuro. Nas rochas sedimentares a cor negra intensa é devida à presença de substâncias betuminosas. Nas rochas magmáticas essa cor é devida à presença de minerais escuros. A cor verde tem origem diferente para mármore ou granito. No mármore é devida à presença de clorita, na oficalcita é devida à presença de clorita e serpentina. Nos granitos pode ser clorita ou sais de ferro, cobre, manganês e de minerais como a actinolita, anfibólio, enstatita e piroxênio. 
Na prática comercial é possível subdividir as cores das rochas ornamentais em três grupos distintos. O primeiro grupo é das cores clássicas e de elevada qualidade, dentre eles, no granito, o preto na sua cor mais intensa e o vermelho. No mármore, o branco e o verde sempre têm preço e mercado. O segundo grupo compreende uma gama grande de violáceo, o azul, etc. Essas cores são chamadas cores exóticas.Enfim, o terceiro grupo compreende as cores mais comuns, cinza e rosa (granito) e de marron a bege (mármore), de grande uso,porém, de baixo preço. Bradley(1998), do ponto de vista comercial, classificou os mármores e granitos por grupos de cores, conforme a Tabela 3.6. O Sindicato de Mármores e Granitos do Estado de São Paulo (2000) classifica os mármores e granitos segundo suas cores (Tabela 3.7.)

Tabela 3.6.Classificação comercial dos mármores e granitos segundo grupo de cores.

\begin{tabular}{|c|c|c|c|c|}
\hline \multirow{4}{*}{$\begin{array}{l}\text { Características do } \\
\text { Mercado Mundial }\end{array}$} & Cor & $\begin{array}{l}\text { Facilmente } \\
\text { utilizável }\end{array}$ & Possibilidade de emprego limitada & $\begin{array}{l}\text { Facilmente } \\
\text { utilizável }\end{array}$ \\
\hline & Custo & $\begin{array}{l}\text { Médio a } \\
\text { alta }\end{array}$ & Médio a alto & Baixo \\
\hline & Disponibilidade & Constante & Inconstante & $\begin{array}{l}\text { Elevada e } \\
\text { constante }\end{array}$ \\
\hline & Qualidade & Alta & Alta & Média \\
\hline & & $\begin{array}{c}\text { Cor } \\
\text { Clássica }\end{array}$ & Cor Especial & Cor Comum \\
\hline \multirow{19}{*}{ Rochas } & GNAISSE & Amarelo & Marrom & Cinza \\
\hline & & Rosa & & \\
\hline & & Verde & & \\
\hline & & Vermelho & & \\
\hline & GRANITO & Azulado & Amarelo & Cinza \\
\hline & & Branco & Azul & Rosa \\
\hline & & Marrom & Verde & \\
\hline & & Preto & & \\
\hline & & Vermelho & & \\
\hline & $\begin{array}{l}\text { GRANITO } \\
\text { MOVIMENTADO }\end{array}$ & Rosa & Amarelo & \\
\hline & & Vermelho & Verde & \\
\hline & & & Violácio & \\
\hline & MÁRMORE & Branco & Amarelo & Bege \\
\hline & & Preto & Marrom & Cinza \\
\hline & & Rosa & Violeta & \\
\hline & & Verde & & \\
\hline & & Vermelho & & \\
\hline & TRAVERTINO & Rosa & Amarelo & Bege \\
\hline & & Vermelho & & \\
\hline
\end{tabular}




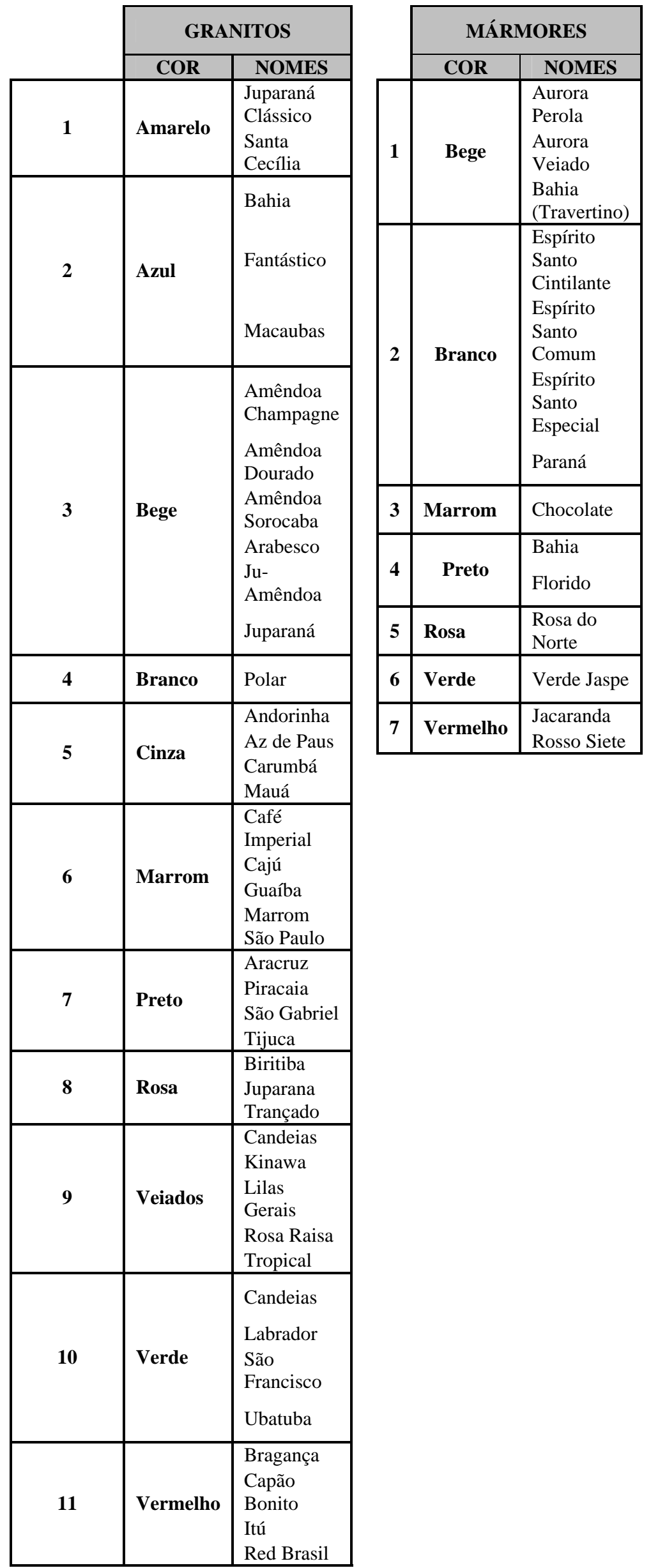

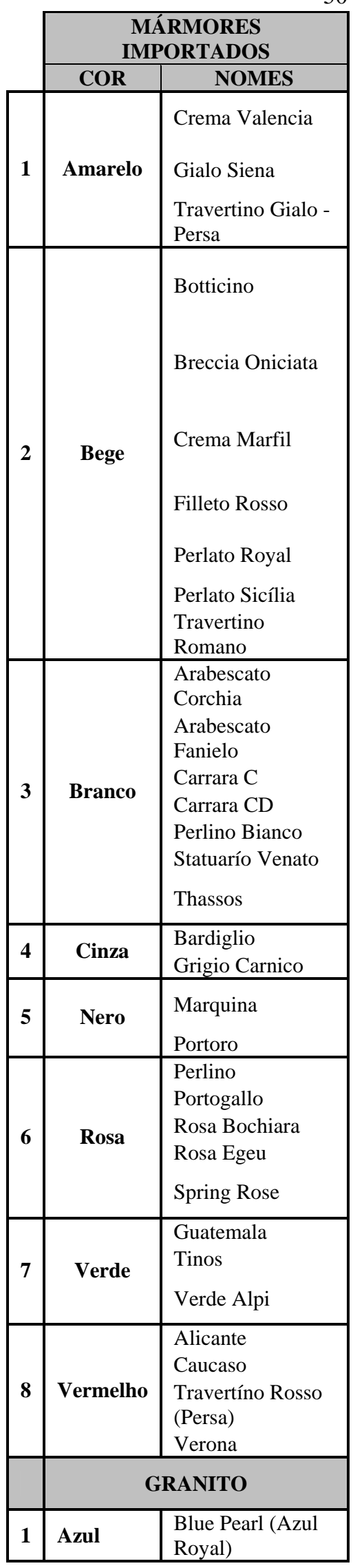




\section{CORES}

\subsection{As cores nos ambientes}

Segundo Ribeiro (1987), a luz é formada por uma mistura de diferentes radiações de distintas frequências de onda. A mistura de todas as ondas simultaneamente e uniformemente produz a percepção do branco. A luz colorida é indicada por uma parte da luz branca.A cor é uma sensação que é despertada quando a luz penetra na retina do olho. A luz é advinda de uma fonte luminosa natural ou artificial, como: o sol, o fogo, lâmpada incandescente, etc. Cada centro luminoso emana ondas ou vibrações que possuem sua própria longitude ou freqüência que, impressionando a visão, passam a sensação de luz. Pelo fato das ondas terem suas próprias freqüências diferenciadas resultam em cores distintas. Sendo assim, a cor branca é o resultado da combinação de muitos raios coloridos e a visão humana consegue perceber somente parte dela.

Em 1666, Isaac Newton demonstrou que um raio de luz branca, luz solar ou qualquer fonte equivalente sofreria uma decomposição ao atravessar um prisma de cristal.

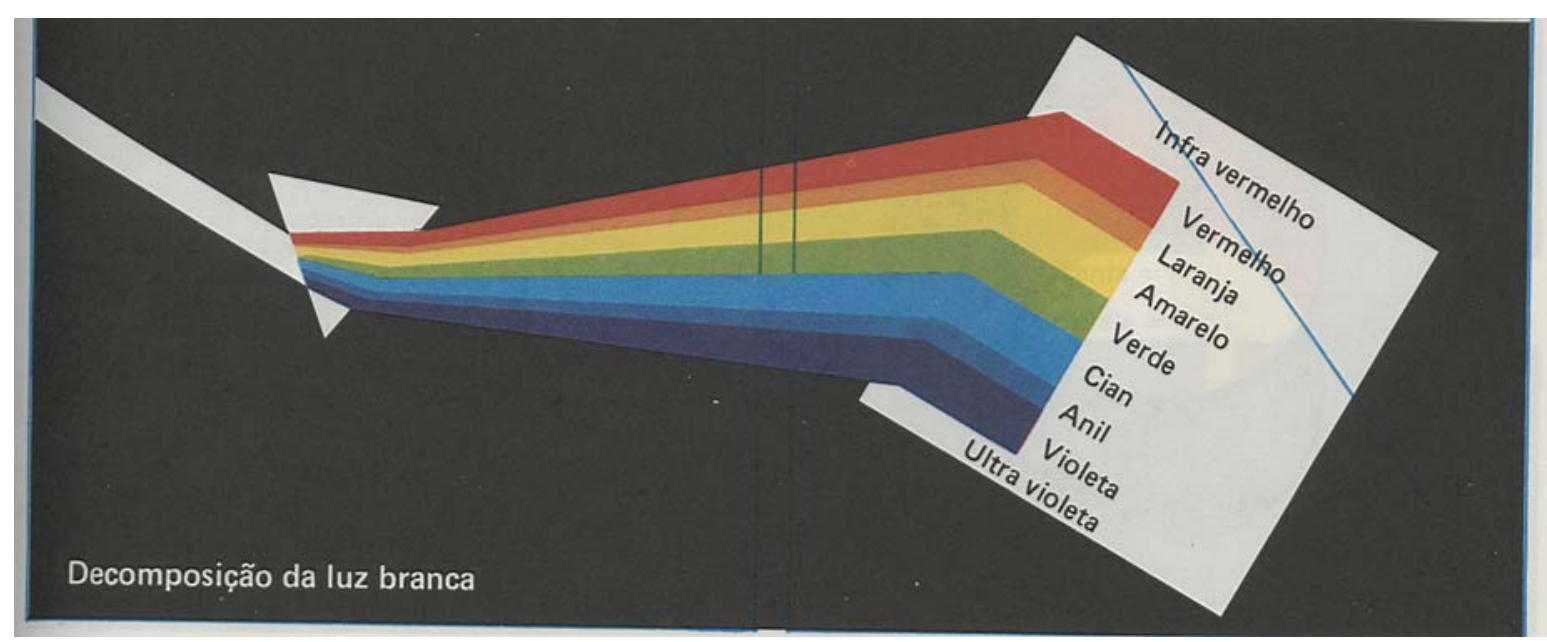

Fig. 4.1 Decomposição da luz branca. 
Esta decomposição é formada pelas cores que compõem o espectro solar e são vistas pelo olho humano. São elas, o vermelho, o amarelo, o verde, o ciano, o índico e violeta, cores estas que formam o arco-íris.

Pode-se recompor a cor branca através do disco de Newton com a mistura das luzes coloridas do arco-íris. Basta girar rapidamente o disco no qual estão pintadas as cores do espectro, e aparecerá a cor branca. Isto porque, as imagens persistem no olho até o estímulo luminoso cessar, pois as imagens são sobrepostas e o olho humano vê a cor branca.

É possível também fazer a projeção de apenas três luzes coloridas: vermelha, verde e violeta. Com a superposição das projeções é possível identificar outras cores coloridas e ao mesmo tempo onde estas cores são recompostas, aparece a cor branca.

A cor depende diretamente da luz. Um exemplo seria simular um ambiente escuro onde não se veria a cor de nenhum corpo e eles pareceriam possuir a cor preta. Isso se deve a inexistência de luz. Os corpos por meio das fontes luminosas têm suas cores diferenciadas possíveis de serem vistas a olho nu. No caso da cor-luz ela é a própria cor e no caso da cor-pigmento, ela, a luz, que é refletida pelo material, faz com que o olho humano perceba esse estímulo como cor.

As cores podem ser primárias, secundárias e terciárias.Na cor-luz, as cores primárias são: vermelho, verde e azul. A mistura destas três cores produz o branco.

A escolha das cores dos mármores e granitos sempre foi um desafio para engenheiros e arquitetos com o objetivo de conseguir uma aparência agradável e harmoniosa em seus projetos.

A cor desde os tempos antigos é considerada como uma característica física do material e, por outro lado, como um fenômeno capaz de induzir as mais variadas sensações psicológicas nos seres humanos.

Ter noção exata das cores a serem usadas em um determinado ambiente é um dos elementos mais importantes para a decoração. Mesclando técnica e bom senso é possível alegrar ou dar um ar 
todo diferenciado a qualquer ambiente, desde um pequeno lavabo, até grandes salas comerciais ou residenciais.Por isso, a escolha das cores é um elemento de vital importância, pois ela tem a capacidade de estimular determinadas sensações.

Segundo Fernandes (2004), cores vivas causam um aspecto excitante, notadamente quando utilizadas de forma contrastantes. Cores neutras denotam um aspecto calmo e tranqüilo. As cores se dividem em quentes (vermelho, amarelo e laranja), frias (azul, verde e violeta) e neutras (branco, preto e cinza). Grande parte dos profissionais que atuam na área de decoração recomenda que seja obedecido um equilíbrio entre cores quentes, frias e neutras. Se as cores frias são predominantes em seus móveis, escolha uma tinta de cor quente para a parede. Em ambiente tranqüilo, como de estudo, devem prevalecer cores neutras.

Utilizando-se a cor-luz, teremos:

Cores primárias - são o vermelho, o verde e o azul. A mistura destas cores produz a cor branca.

Na cor-pigmento opaco, as primárias, são: vermelho, amarelo e azul.

Nas artes gráficas e para todas que utilizam cor-pigmento transparente, as cores primárias, são: magenta, amarela e ciano. A mistura em partes iguais destas três cores produz o preto. As cores-pigmentos transparentes, magenta, amarela e ciano são chamadas de primárias porque não podem decompor-se em outras cores e de sua mistura se extraem as outras cores. Estas cores obtidas são chamadas compostas e gradualmente se obtêm as secundárias e as terciárias.

Cores secundárias - resultante da mistura de duas cores primárias. Exemplo: verde + azul resulta a cor ciano, azul + vermelho resulta a cor magenta, vermelho + verde resulta a cor amarela, azul + vermelho resulta a cor violeta e vermelho + amarelo resulta a cor laranja.

Cor terciária - ao se misturar uma cor primária com uma secundária que a contenha o resultado será uma cor terciária.

Dentre as sugestões de esquemas decorativos para ambientes, dados por Dicas de Decoração (2004), são citadas: 
Simples - fundo neutro + tom forte de uma cor. Exemplo: ambiente branco ou marfim + tons vermelhos.

Complexo - fundo neutro + escolha de duas cores diferentes, porém combinadas. Exemplo: ambiente marfim + tons vermelhos e caramelos.

Complexo e harmonioso - fundo neutro + escolha de três cores diferentes, sendo duas cores quentes e uma fria. Exemplo: ambiente branco + cor laranja, amarela e verde.

Tranqüilizante - fundo neutro + cores frias. Exemplo: ambiente branco + tons azuis.

Exaltante - fundo neutro + cores quentes. Exemplo: ambiente branco + tons vermelhos.

A Abdicas (2004) possui um programa que permite escolher 5 cores que combinam suavemente com uma determinada cor.

Basta definir a cor desejada usando o mouse nas 3 barras de cores primárias. Automaticamente as 5 outras cores serão apresentadas e classificadas segundo o sistema Hexagonal. No capítulo 4, será comentado o significado do sistema Hexagonal.

Na Fig.5.2 encontra-se um exemplo de aplicação do programa. Existem também outros programas como o ColorMania que possuem esse recurso (Fig.5.1).

Sugestões para esquemas de ilusão de ótica:

Encurtando o ambiente - Para uma sala retangular muito comprida, pintar as paredes menores com uma cor mais escura.

Alongando ambiente quadrado - Aplicar cor mais escura em duas paredes, uma de frente para a outra.

Escondendo objetos - Pintar a parede com a cor do objeto que se pretende esconder.

Destacando objetos - Pintar a parede na cor contraria do objeto que se pretende destacar.

Rebaixando o teto - Pintar o teto com uma cor mais escura do que a das paredes.

Elevando o teto - Pintar o teto com uma cor mais clara do que a das paredes.

Alargando o corredor - Pintar as extremidades do corredor (paredes menores) e o teto com uma cor mais escura do que as paredes que acompanham o sentido do corredor. 
Alongando a parede - Neste caso é fundamental que a parede seja bicolor, com uma divisão entre as duas cores a meia altura nessa separação. Na parte de cima da parede a cor deve ser mais clara do que a cor da parte de baixo.

Encurtando a parede - A situação é inversa do exemplo anterior. A parte de cima da parede deve ser de cor mais escura que a parte de baixo.

\subsection{Identificação das cores}

Teoricamente, no aspecto físico, as cores são classificadas em três dimensões: tom, valor e saturação. O tom é a qualidade que distingue uma cor da outra; o valor significa a quantidade de luz que uma superfície tem capacidade de refletir. Assim, um vermelho claro tem valor mais alto que um vermelho escuro; a saturação esta relacionada com a pureza ou a opacidade da cor. Para representar essa classificação elaboraram-se vários esquemas como a pirâmide de Lambert, o duplo cone de Ostwald e a ordenação criada por Munsell. Estes sistemas baseiam-se no mesmo princípio. O eixo vertical representa as escalas de valores acromáticos, que vão desde o branco na parte superior até o negro na inferior. O círculo correspondente ao equador contém a escala dos tons que possuem um valor da claridade média. Cada uma das seções horizontais do sólido apresenta os valores cromáticos num dado nível de claridade. Quanto mais afastado do eixo central, mais saturada será a cor e quanto mais próximo, mais misturada com um cinza de mesmo valor.

A cor do ponto de vista físico é um processo primário da percepção. É dentro deste aspecto que será desenvolvido o trabalho. Serão estudados os método comparativo e o instrumental. Quando se deseja uma definição precisa da cor, evitando uma avaliação comparativa subjetiva pode-se aplicar o método instrumental.A metodologia comparativa utiliza uma comparação simples entre duas cores, enquanto que o método instrumental realiza uma avaliação quantitativa.

Uma apresentação simples e unificada das cores é de grande importância para os projetos de engenharia civil e arquitetônico. 
Munsell (1947) apresentou os três atributos das cores (tom, valor e saturação) no que ele denominou de esfera das cores, onde os atributos são apresentados com escala de valores e as observações da esfera são feitas a olho nu na luz do dia ,podendo ser comparadas e analisadas com as cores dos materiais em estudo.

A denominada esfera de cores de Munsell encontra-se na Fig. 4.2

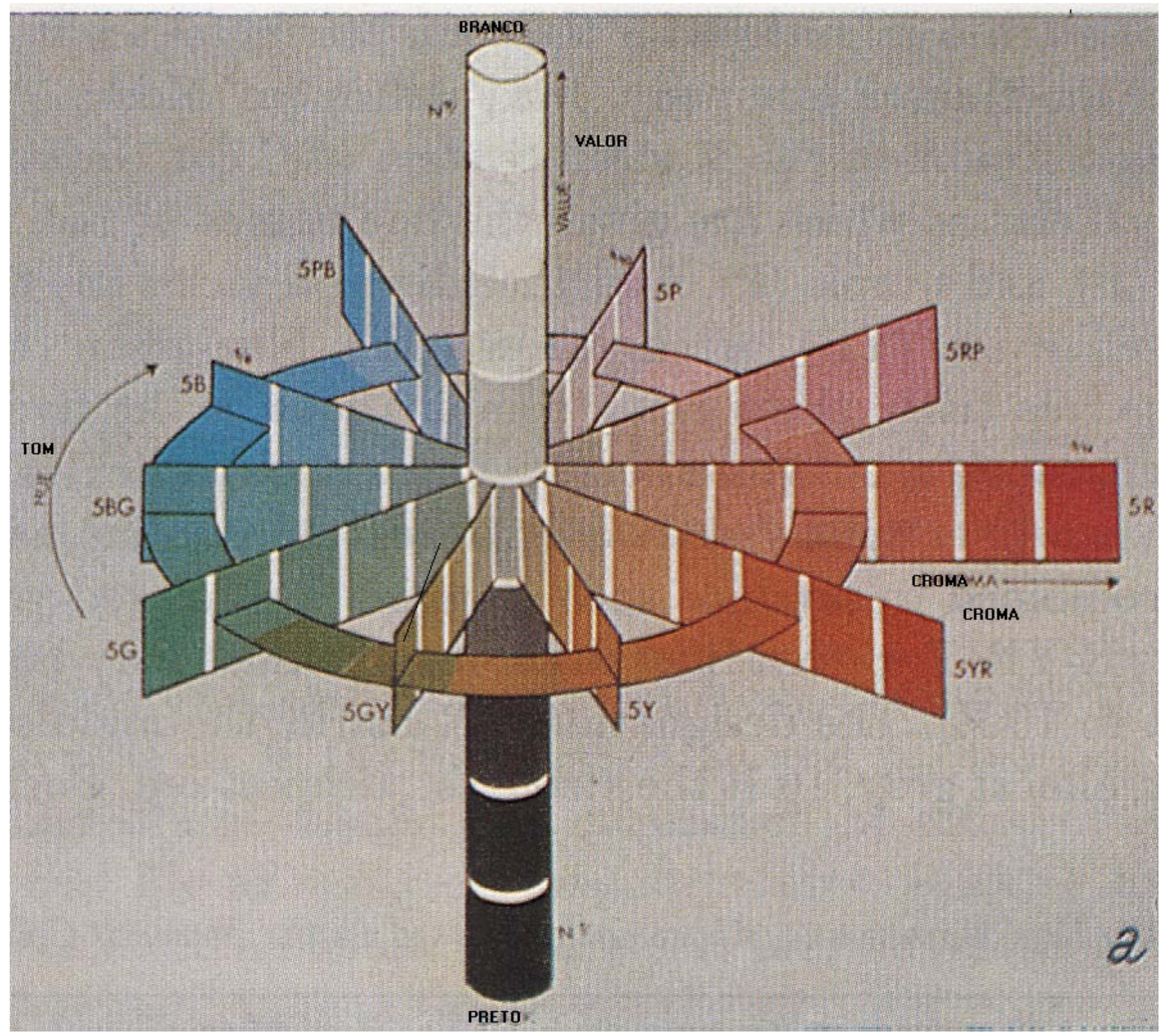

Fig. 4.2 Esfera de Cores de Munsell

O tom (Hue) no Sistema de Cores de Munsell é dividido em 5 classes com as seguintes denominações: vermelho (R), amarelo (Y), verde (G), azul (B) e púrpura (P). Pode-se também usar classes intermediárias como: amarelo - vermelho (YR), verde - amarelo 
(GY), azul - verde (BG), púrpura - azul (PB) e vermelho - púrpura (RP). Pode-se usar subdivisões mais especificas como, vermelho - amarelo - vermelho (RYR), etc. As classes estão subdivididas em valores que vão de 1 a 10 . A designação $5 \mathrm{R}$ marca a metade da cor cromática vermelha, onde $1 \mathrm{R}$ representa a cor vermelha mais próxima da cor cinza e $10 \mathrm{R}$ a cor vermelha mais intensa.

Croma (Chroma) - Indica a saturação ou grau de intensidade de um tom desde um cinza neutro até sua cor mais intensa. A escala de valores vai desde 0 até 14 , dependendo do grau de saturação da cor em questão.

Valor (Value) ou Luminância - Indica o grau de brancura ou de escuridão de uma determinada cor com relação a uma escala neutra de cinza, a qual se estende numa direção vertical desde um preto puro simbolizado pelo número 0 na parte inferior, até um puro branco simbolizado pelo número 10 na parte superior.

\subsection{Métodos propostos de Identificação}

\subsubsection{Método de comparação direta}

A Sociedade Geológica da América baseou-se no trabalho de Munsell para elaborar a Carta de Cores das Rochas, sistema RCC, editada por Goddard (1951) que se constitui num importante trabalho na determinação das cores das rochas por comparação direta.

A Carta de Cores das Rochas se adapta muito bem quando aplicada a rochas de grãos médios a finos. No estudo das cores no caso de rochas com grãos grossos pode-se adotar o procedimento de determinação de mineral por mineral ou colocando a amostra da rocha a uma determinada distância que torne possível a comparação entre as cores. A amostra objeto de estudo pode estar seca ou molhada. A cor da rocha molhada é bastante semelhante à cor que se observa quando a rocha estiver lustrada. Pode-se também comparar as cores da Carta de Cores das Rochas com as cores das amostras projetadas no vídeo do computador.

Para facilitar a comparação da Carta de Cores com a amostra em estudo, foram estabelecidas nesta tese 6 folhas onde aparecem os três elementos identificadores das 
cores de uma forma de fácil compreensão e de uso simples para comparação com a amostra. Essas folhas aparecem no Anexo A.

Abaixo das cores apresentadas, além do nome da cor aparecem os três elementos identificadores, segundo Munsell. Tomando por exemplo, a cor vermelha pálida tem a identificação 10 R 6/2 o que significa (Fig. 4.2) um vermelho mais próximo da cor púrpura, com um valor 6 e uma saturação 2.

A redução do número de cores da Carta de Cores das Rochas com relação a proposta de Munsell se deve ao levantamento de cores de rochas de várias origens feito por várias entidades e profissionais ligados a geologia. Não é uma carta de cores voltada especificamente para rochas ornamentais.

\subsubsection{Classificação}

Ruffa et al. (1998) nos mostra que os aparelhos de medidas existentes no mercado foram desenvolvidos objetivando operar em outros tipos de superfícies tais como vernizes, tintas e etc. Sua utilização para mármores e granitos é uma adaptação.

Outra crítica feita a esses aparelhos é que durante as medidas os valores obtidos são uma média de uma pequena área da amostra estudada. Isso dificulta a definição dos atributos reais da cor da amostra, pois no caso dos mármores e granitos dada suas origens genéticas, com relação à cor, eles apresentam variações.

Na Foto. 4.1. está mostrado um desses aparelhos existentes no mercado, extraído de Ruffa et al. (1998). 


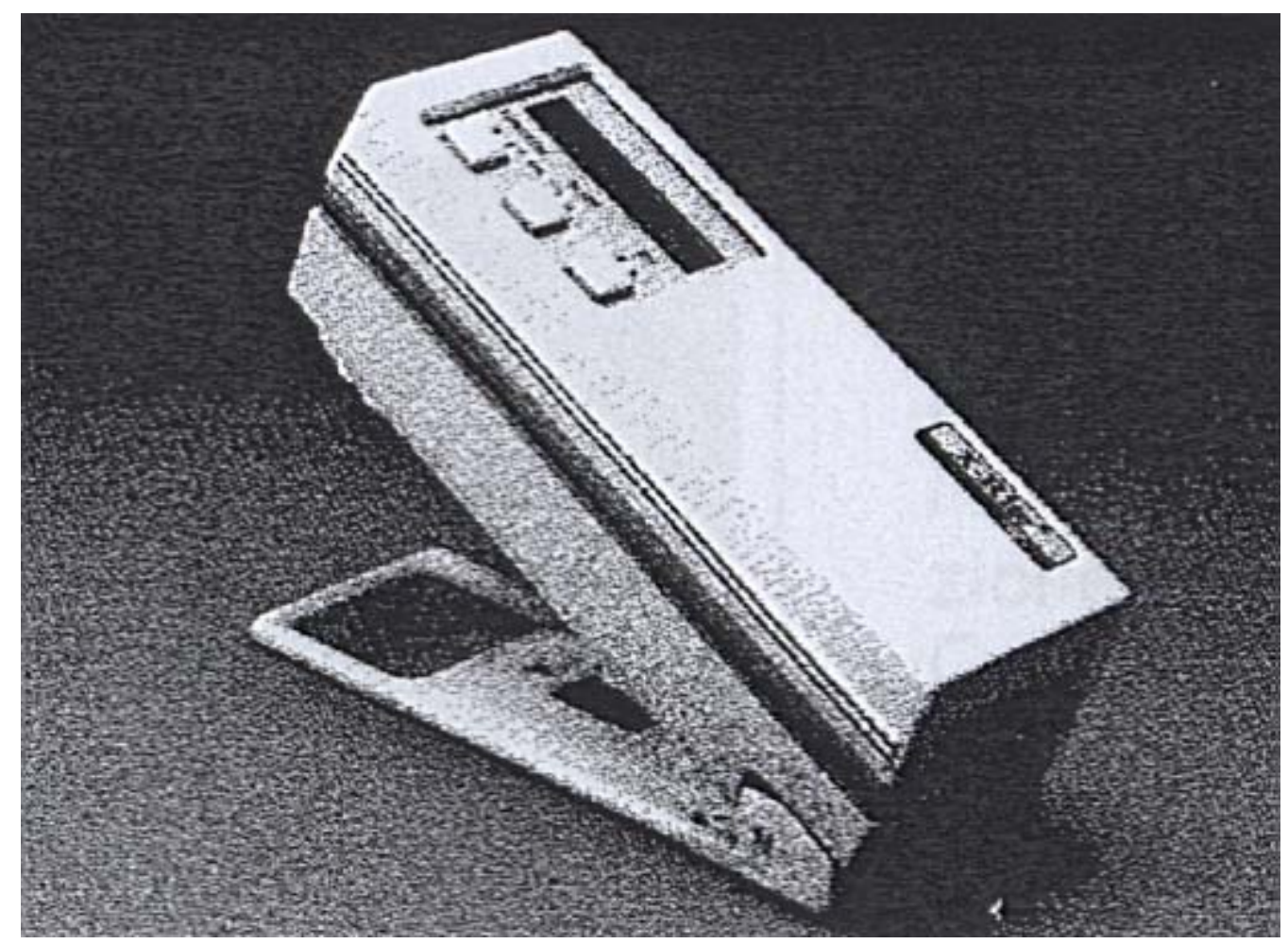

Foto.4.1. Espectrocolorimetro X-RITE 948 da Erichsen.

Motoki et al. (2005) apresentam estudos científicos com relação à determinação das cores das rochas ornamentais, porém de pouco interesse para os nossos objetivos.

Modernamente se utiliza a criação de bancos de dados computadorizados, usando os recursos da informática com dispositivos de uso comum. Com o aparecimento das câmeras fotográficas digitais de alta resolução é possível fotografar amostras, passando essas fotos diretamente para um banco de dados existente no computador, conforme se mostra sucintamente na Fig. 4.4.

É possível também escanear diretamente amostras de rocha lustrada ou de fotos de amostras.

Esses dados podem ser ampliados com outras informações tecnológicas, possibilitando comparações com outros materiais semelhantes existentes no Banco de Dados. 
Existem Empresas, Institutos de Pesquisa e Universidades que fornecem Bancos de Dados de materiais nacionais e internacionais em CD-ROMs, de fácil aquisição.

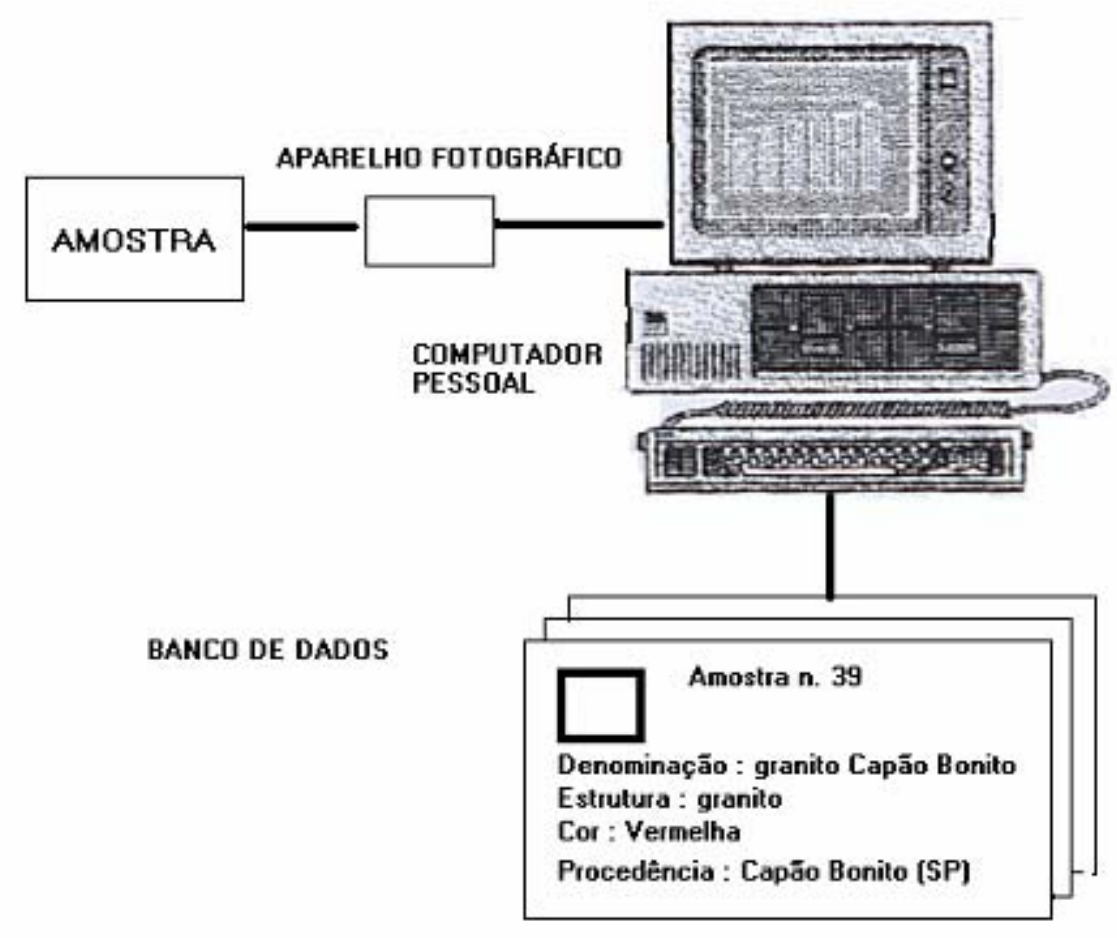

Fig.4.4 Criação do banco de dados em computador.

\section{Sistema RGB}

Mattos (2004) comenta que é possível criar uma cor combinando três ondas de cores, (vermelho, verde e azul) para simular uma cor encontrada na natureza. Essas três cores são a base do sistema RGB (Red - vermelho, Green - verde e Blue - azul) existentes nos monitores, televisores e escaners.

Juntando essas três cores, obtém-se a cor branca. Retirando-se as três cores resulta a cor preta.O conjunto das três cores e suas respectivas intensidades pode gerar até 16 milhões de cores. 
Denomina-se (pixel) a menor unidade de cor gerada no monitor por um ou mais pontos coloridos.

No sistema RGB a intensidade de cada componente de cor, que varia de 0 a 255, determina a cor final. Por exemplo, a cor branca, que é a mais clara de todas é formada pela intensidade máxima de todos os componentes de cor. Portanto, o seu valor é de 255, 255,255 para os componentes RGB. A cor preta, que na verdade é a ausência de qualquer componente de cor, tem valor $0,0,0$. As outras cores são geradas através da combinação de outros valores.

É comum o uso do sistema Hexagonal cuja representação é feita por letras em lugar de números, assim a cor branca no sistema RGB tem o valor 255, 255, 255 e no sistema Hexagonal será representada pelas letras \#FFFFFF, onde cada valor (255) é representado por FF. Nos métodos de identificação, apresentados adiante, aparecem as duas nomenclaturas ao mesmo tempo.

Nas aplicações é mais interessante o uso da nomenclatura RGB do que a Hexagonal, pois ela nos dá as proporções usadas das cores primárias para compor uma cor escolhida.

\subsubsection{Comparações entre os sistemas RCC e RGB}

Verifica-se que o sistema RCC não possui todas as cores encontradas nas rochas ornamentais e durante a sua utilização é mais comum a interpolação da cor da rocha com as cores encontradas nas tabelas.

No sistema RGB é possível determinar a cor semelhante à cor da rocha. Assim, o sistema RCC deve ser utilizado em trabalhos de campo e o sistema RGB em laboratório por fornecer comparações mais precisas.

Utilizando conjuntamente os programas Color Detector e o ColorPicker, pode ser estabelecida a equivalência entre os sistemas RCC e RGB (Tab. 4.1). 
Tabela 4.1 Comparações entre Valores RCC e RGB

\begin{tabular}{|c|c|c|c|c|c|}
\hline RCC & RGB & RCC & RGB & RCC & RGB \\
\hline 5R 8/2 & $240,212,92$ & BG4/6 & 56,96,96 & $5 Y 4 / 4$ & $104,104,48$. \\
\hline $5 \mathrm{R} 7 / 4$ & $240,164,144$ & BG3/2 & $\begin{array}{l}56,88,72 \\
\end{array}$ & $5 Y 3 / 2$ & $72,80,56$ \\
\hline 5R6/2 & $184,116,96$ & $5 \mathrm{~B} 8 / 2$ & $208,228,224$ & $10 \mathrm{Y} 8 / 2$ & $216,228,176$ \\
\hline 5R6/6 & $216,116,104$ & $5 B 7 / 6$ & $152,200,208$ & $10 \mathrm{Y} 7 / 4$ & $176,180,104$ \\
\hline $5 \mathrm{R} 5 / 4$ & $184,88,80$ & $5 \mathrm{~B} 6 / 2$ & $128,160,152$ & $10 \mathrm{Y} 6 / 2$ & $160,168,120$ \\
\hline $5 \mathrm{R} 4 / 2$ & $128,64,56$ & $5 B 5 / 6$ & $80,132,160$ & $10 \mathrm{Y} 6 / 6$ & $160,160,40$ \\
\hline $5 \mathrm{R} 4 / 6$ & $176,52,48$ & $5 \mathrm{~PB} 7 / 2$ & $184,204,200$ & $10 \mathrm{Y} 5 / 4$ & $120,132,56$ \\
\hline $5 \mathrm{R} 3 / 4$ & $128,40,40$ & 5PB5/2 & $120,132,136$ & $10 \mathrm{Y} 4 / 2$ & $96,104,64$ \\
\hline $5 \mathrm{R} 2 / 2$ & $88,36,32$ & 5PB3/2 & $64,76,80$ & N9 & $255,255,255$ \\
\hline $5 \mathrm{R} 2 / 6$ & $112,28,32$ & $5 \mathrm{P} 6 / 2$ & $176,160,168$ & N8 & $216,220,200$ \\
\hline 10R8/2 & $248,216,192$ & $5 \mathrm{P} 4 / 2$ & $104,96,96$ & N7 & $168,176,160$ \\
\hline 10R7/4 & $232,169,128$ & $5 \mathrm{P} 2 / 2$ & $64,64,72$ & N6 & $136,144,136$ \\
\hline 10R6/2 & $192,136,112$ & 5RP8/2 & $224,212,192$ & N5 & $120,124,112$ \\
\hline 10R6/6 & $224,112,72$ & 5RP6/2 & $168,152,152$ & N4 & $88,100,88$ \\
\hline 10R5/4 & $184,96,72$ & 5RP4/2 & $120,100,96$ & N3 & $64,72,64$ \\
\hline 10R4/6 & $168,60,40$ & $5 Y 8 / 4$ & $216,216,136$ & N1 & $0,0,0$ \\
\hline 10R3/4 & $120,40,32$ & $5 Y 7 / 2$ & $184,184,136$ & & \\
\hline 10R2/2 & $88,32,32$ & $5 Y 7 / 6$ & $200,180,64$ & & \\
\hline $5 B G 7 / 2$ & $152,192,168$ & $5 Y 6 / 4$ & $160,152,80$ & & \\
\hline 5BG6/6 & $104,172,152$ & $5 Y 5 / 2$ & $128,124,80$ & & \\
\hline $5 B G 5 / 2$ & $88,124,112$ & $5 Y 5 / 6$ & $144,136,56$ & & \\
\hline
\end{tabular}




\section{PROPOSTA DE APRESENTAÇÃO DAS AMOSTRAS DE MÁRMORES E GRANITOS}

\subsection{Procedimento normalmente utilizado}

Os produtores e fornecedores de mármores e granitos de um modo geral possuem sites disponíveis na Internet onde apresentam seus produtos na forma de foto de amostras, geralmente em duas escalas e identificando esses produtos pelo nome escolhido por eles. Podem também apresentar esses produtos em catálogos.

Os Institutos de Pesquisa e as Universidades apresentam seus estudos feitos de uma maneira abrangente, onde a maioria das informações que se necessita são abordadas. As amostras por eles estudadas são enviadas pelos produtores mediante solicitação. Na maior parte das vezes as amostras recebidas não correspondem a todos os tipos de rochas existentes na jazida e também com nomes que não traduzem a cor da amostra. Como exemplo, cita-se o caso da pedreira de granito vermelho, situada na Fazenda Somibras, em Capão Bonito, Estado de São Paulo, onde se nota a existência de grandes volumes de granito de cores vermelha, rosa e marrom. No CD-ROM da Empresa YKK do Brasil Ltda., o granito denominado granito vermelho Capão Bonito tem a cor vermelha. Por outro lado, nos CD-ROMs do IPT (2004) e de Corbella (1998) com essa mesma denominação aparece com a cor marrom.

A cor dos mármores e granitos apresentada de uma forma descritiva e subjetiva baseada em fotos ou amostras tem pouco valor no ponto de vista da sua escolha. Isso motivou a principal proposta desta tese, de se fazer a identificação das cores de uma forma objetiva, simples e barata, mediante o uso de recursos disponíveis na informática.

Para isto, Utilizaram-se os programas da Blacksun Software (2004) (ColorMania), da Abdicas (2004) (Cores combináveis), da Diplock (2004) (Color Picker Pro 1.0), da

Silverage Software (2004) (Color Spy 1.01), da Cosmin Software (2004) (Color Detector), todos disponíveis na Internet. 
A função desses programas é determinar as cores das amostras segundo os sistemas RGB, Hexagonal ou Munsell.

Esses programas utilizam dois procedimentos: o primeiro através de determinações puntuais sobre um pixel que representa a cor predominante da amostra da rocha e o segundo possibilita a determinação da cor predominante de uma área parcial ou de uma área total da amostra. Esses programas também apresentam de 5 a 6 cores combináveis com a cor escolhida, de grande importância nos projetos arquitetônicos.

A Fig 5.1 apresenta um exemplo do programa ColorMania e os recursos nele disponíveis. Neste programa são mostrados os valores equivalentes entre os sistemas RGB, Hexagonal e Munsell.

A Fig.5.2. mostra a utilização conjunta de dois programas (Cores Combináveis e Color Detector).

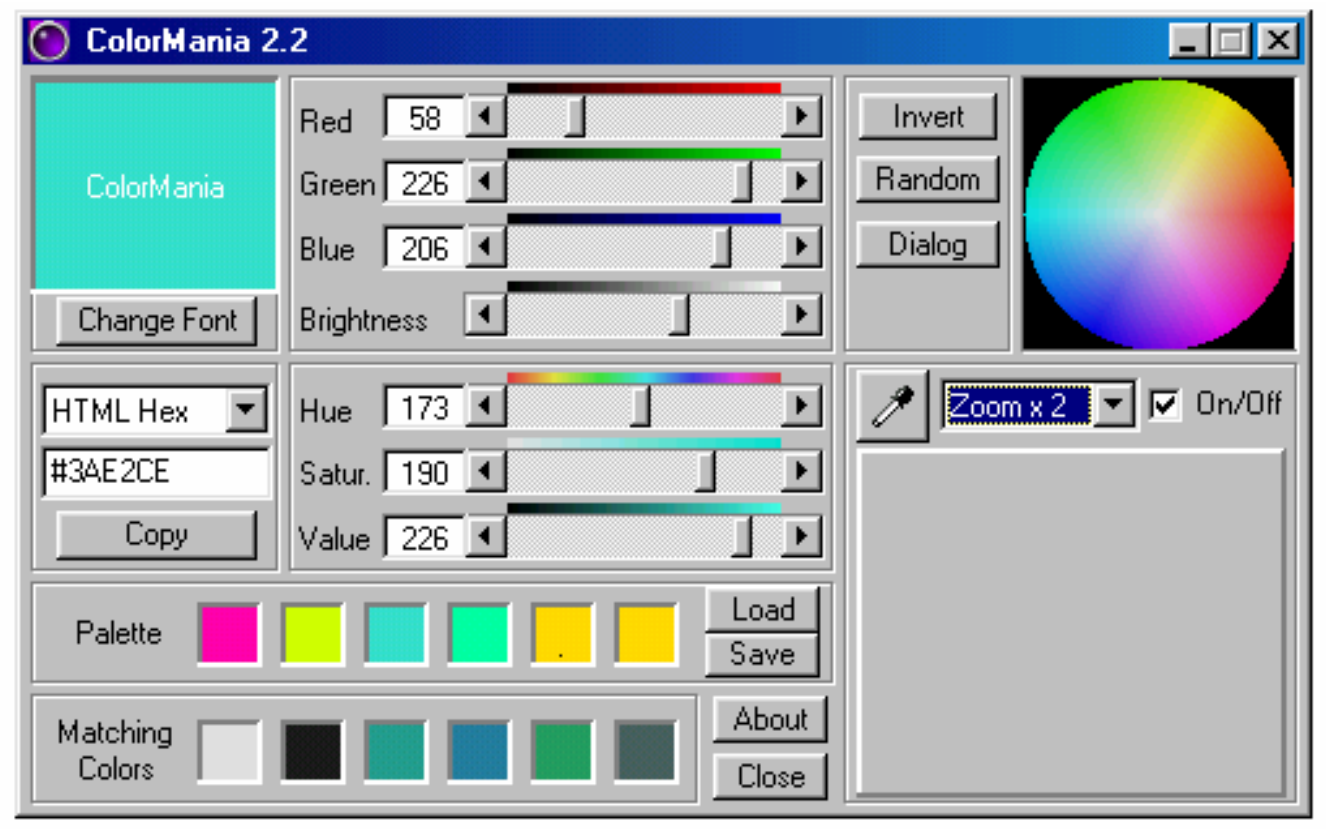

Fig 5.1 Programa ColorMania e seus recursos disponíveis. 
Todos esses programas se interagem e podem ser colocados na tela do vídeo simultaneamente.

Alem desses programas foram usados os programas disponíveis noWindows, tais como Paint, Paint Shop Pro e Imaging.

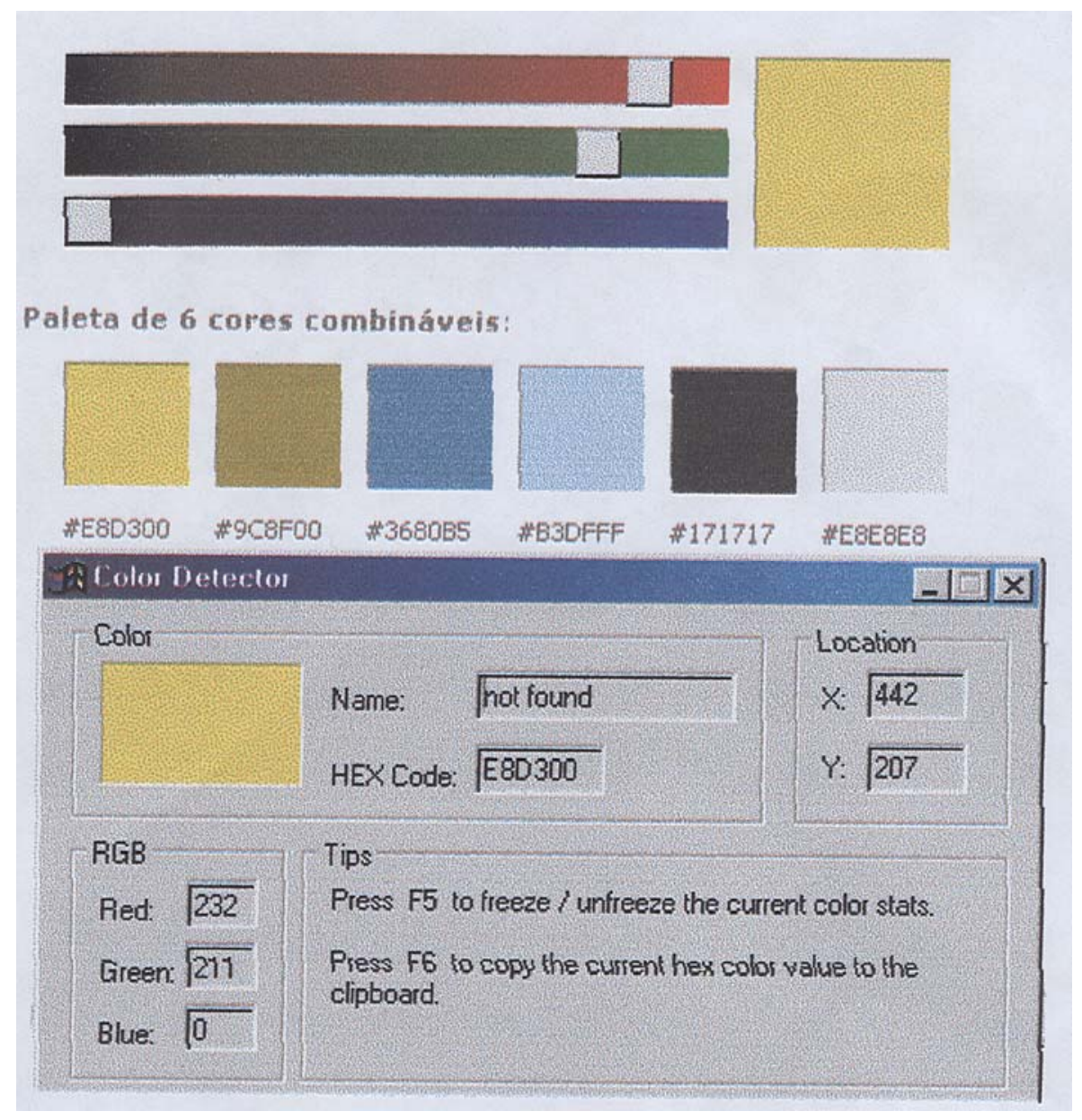

Fig.5.2 Utilização conjunta de dois programas (Cores Combináveis e Color Detector) na determinação dos valores RGB e Hexagonal equivalentes. 


\subsection{Proposta de apresentação das amostras}

Estruturou-se a apresentação das amostras de uma maneira sucinta, para que o projetista possa ter maior facilidade na escolha dos materiais que deverá usar.

Na Figura 5.3 são apresentados os elementos de informações que poderão servir como fonte imediata de consulta.

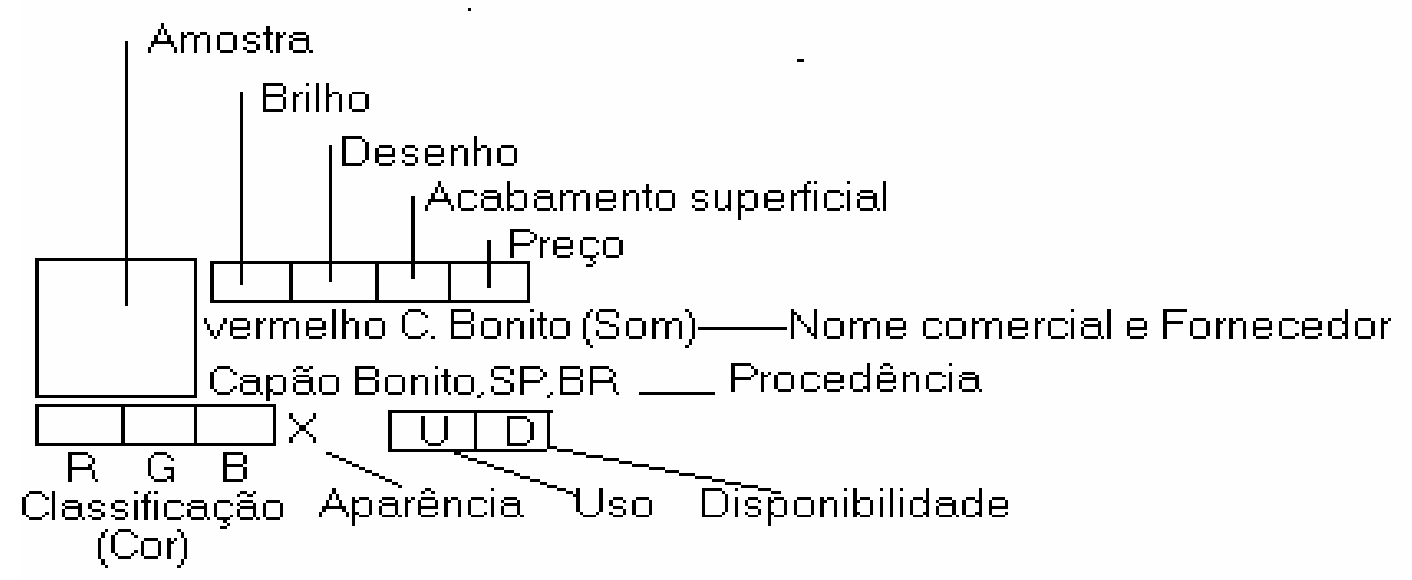

Fig. 5.3 Proposta de apresentação das amostras.

Os significados de cada item são os seguintes:

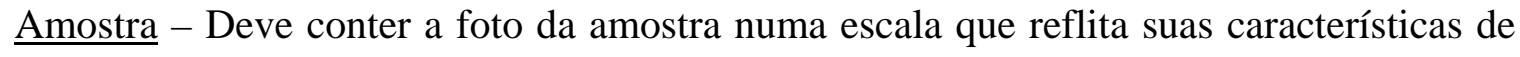
cor numa visão afastada do observador, assim a cor dominante será a que irá caracterizar a amostra.

Brilho - O brilho será indicado pelas letras:

A - brilho adamantino, L - brilho leitoso, O - brilho oleoso, R - brilho resinoso, S - brilho sedoso e V - brilho vítreo.

Desenho - Que corresponde à estrutura da rocha.

Co - Compacta, N - nodular, Fo - fossilífera, Po - porosa, B - bandeada, Cl - clástica, X xistosa, G - granular, Pf - porfirítica e Fl - fluidal. 
Acabamento superficial

Lt - lustrada, Lv - levigada, F - flameada.

Nome comercial do Produtor e/ou Fornecedor e procedência

Como está indicado na Fig.5.3, Nome do Produtor e/ou Fornecedor é como uma abreviatura de 3 letras. Segue abaixo uma lista, em ordem alfabética, dos produtores e/ou produtores:

(Aço) Aço Mineração Ltda.

(Beb) Bege Bahia Mármores Ltda.

(Bra) Braminas Brasileira de Granitos e Mármores Ltda.

(Brn) Brasgran Brasil Granitos Ltda.

(Cig) Cigrama Companhia Industrial de Granitos Ltda.

(Cju) Cajugran Granitos e Mármores do Brasil Ltda.

(Coc) Mineração Corcovado do Nordeste Ltda.

(Cot) Mineração Coto Comércio Importação e Exportação Ltda.

(Eas) Empresa de Mineração Alto da Serra Ltda.

(Fuj) Fuji S/A Mármores e Granitos.

(Fus) Fuste Granitos Ltda.

(Gac) Gramacap Granitos e Mármores Capixaba Ltda.

(Gas) Gransena Exportação e Comércio Ltda.

(Gmg) G. M. Granitos e Mármores Ltda.

(Gno) Granos Granitos do Nordeste S/A.

(Gra) Gramazon Granitos da Amazônia S/A.

(Grb) Gramobras Granitos e Mármores Brasileiros Ltda.

(Grd) Granorte Granitos do Nordeste do Brasil S/A

(Grl) Granicel Ltda.

(Grm) Granita Brazilian Granites Ltda.

(Grt) Granistone S/A

(Imi) Imil Indústria de Mármores Italva Ltda.

(Imf) Imarf Granitos e Mineração S/A.

(Ita) Itaqua Mármores e Granitos Ltda. 
(Jn) J N Granitos Ltda.

(Mab) Mármores da Bahia S/A.

(Mae) Martinez Espiñedo Exportação de Granitos Ltda.

(Mag) Mag Ban Mármores e Granitos Aquidaban Ltda.

(Mam)Marmifera Sociedade Brasileira Ltda.

(Mar) Marbrasa Mármores Brasileiros S/A.

(Mbj) Minérios de Bom Jardim S/A.

(Mbl) Marbella Granitos e Mármores Ltda.

(Mor) Mineração Morro Grande Ltda.

(Mul) Multigran Mineração e Granitos Ltda.

(Nem) Nemer Mármores e Granitos S/A.

(Neu) Neugramar Granitos Ltda.

(Nor) Nord Mineradora Ltda.

(Pan) Pan Mineração Ltda.

(Pev) Peval S/A.

(Ser) Serraria de Mármores Santo Antonio Ltda.

(Som) Somibras Sociedade de Mineração Brasileira Ltda.

(Tra) Tracomal Mineração Ltda.

(Tres) Mineração Três Corações Ltda.

(YKK) -YKK do Brasil Ltda.

\section{Preços.}

Quanto aos preços estabeleceu-se 10 faixas de valores vigentes no mês de Maio de 2005, na cidade de São Paulo, para chapas lustradas, com 2 centímetros de espessura. Os valores são médios e tem o objetivo de serem comparativos.

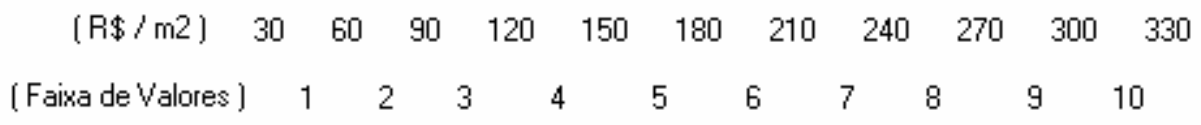




\section{Classificação quanto à cor}

Adotou-se a nomenclatura RGB, cujos números serão colocados nos quadros relativos as letras R (vermelho), G (verde) e B (azul).

Aparência - designada pela letra $X$

Para $\mathrm{X}=0$, quando a aparência com o observador afastado ou próximo da amostra é a mesma.

Para $\mathrm{X}=1,2,3 \ldots$ indica a presença na amostra de um mineral de cor diferente da cor predominante. Quanto maior for o número, maior será o percentual desse mineral.

Para $X=(1,2)$, significa a presença de um segundo mineral com cor diferente da cor predominante e da cor do mineral anterior. Os números quantificam esses minerais de forma comparativa com as outras amostras.

Estudando os granitos pretos pode-se ver com mais clareza esse critério proposto.

Utilizando o zoom dos softwares mencionado na página 61, pode-se evidenciar as cores claras de forma qualitativa e quantitativa, como nos mostra a Foto. 5.1.

\section{Granitos Pretos}

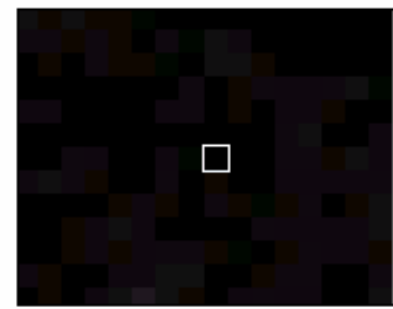

Preto absoluto

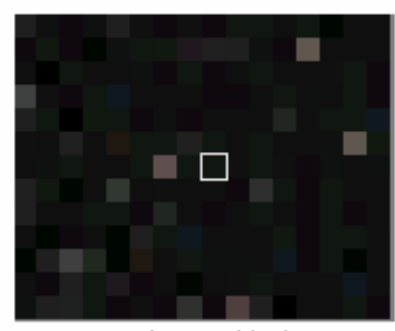

Aracruz black

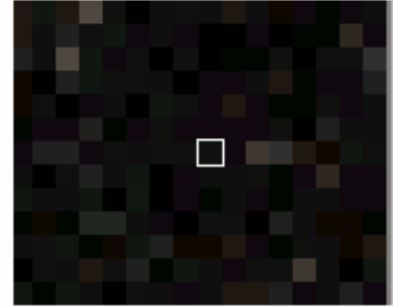

Preto São Gabriel

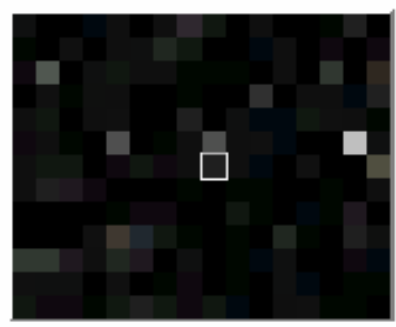

Preto Ceará

Foto 5.1 Visualização das cores claras nos granitos pretos. 
Uso - proposta de uso do material em ambientes diferentes.

I - Uso interno, E - Uso externo, A - Uso interno e externo.

Disponibilidade

D - material disponível em qualquer quantidade, $\mathrm{R}$ - quantidade disponível restrita e $\mathrm{N}$ não disponível.

As obtenções dos preços e da disponibilidade dos mármores e granitos foram feitas por telefone ou por e-mail diretamente com os fornecedores da cidade de Cachoeiro de Itapemirim (Estado do Espírito Santo) e de São Paulo e pela publicação da Pauta para preços mínimos de mármores e granitos no Diário Oficial do Estado do Espírito Santo (2004).

Para determinação dos valores RGB das amostras, adotamos dois procedimentos diferentes. Um deles utilizando o programa Colormania, lançando-se a foto da amostra na tela do computador e o programa Colormania simultaneamente. Com o auxilio do conta gotas do programa procura-se na amostra o mineral cuja cor, por comparação se assemelha a cor da amostra.Os valores RGB podem ser lidos diretamente. Outro procedimento utiliza o Paint Shop Pro. Lança-se a foto da amostra na tela do Paint Shop Pro e em seguida clica-se na barra de ferramentas o Histograma que apresentará os valores RGB de toda área da amostra.

\section{Programas de informática utilizados}

Foram utilizados os programas mencionados no item 5.1, todos disponíveis na Internet. A função desses programas é determinar as cores das amostras segundo o sistema RGB, Hexagonal ou Munsell. Eles determinam as cores usando dois procedimentos diferentes; o primeiro através de determinações pontuais sobre um pixel que representa a cor predominante da rocha, que é facilmente localizada. O pixel pode ser obtido mediante o dispositivo zoom existente nesses programas; o segundo possibilita a determinação da cor predominante de uma área parcial ou da área total da amostra. 
Eles apresentam também 5 a 6 cores combináveis com a cor predominante da amostra que é de grande utilidade nos projetos de arquitetura.

Para elaboração do exemplo de intervenção arquitetônica utilizou-se o programa Gimp 2.1 da PC Expert (2004). Programa como esse, ou semelhante, estão em CD-ROMs disponíveis em revistas especializadas que podem ser encontradas em bancas de jornal, livrarias, etc.

Foram utilizados programas auxiliares existentes no Windows, tais como, Paint e Photo Paint.

Quando se incluem rochas ornamentais no rol dos mármores e granitos, certas características prévias devem ser obedecidas.

1 - A rocha deve permitir o lustro.

2 -A rocha deve ter características tecnológicas mínimas como as citadas na Tabela 5.1, cujos dados foram publicados pelo Instituto de Pesquisas Tecnológicas do Estado de São Paulo (2004). 
Tabela 5.1 Especificações para rochas ornamentais.

\begin{tabular}{|l|l|l|l|l|l|}
\hline $\begin{array}{l}\text { Característica } \\
\text { Tecnológica }\end{array}$ & Granito & Mármore & Calcário & Travertino & Serpentinito \\
\hline $\begin{array}{l}\text { Densidade aparente } \\
\left(\mathrm{Kg} / \mathrm{m}^{3}\right)\end{array}$ & $>2.560$ & $>2.525$ & $>1.760$ & $>2.305$ & $>2.560$ \\
\hline Absorção d'água (\%) & $<0,4$ & $<0,20$ & $<12$ & $<2,5$ & $<0,2$ \\
\hline $\begin{array}{l}\text { Resistência à } \\
\text { compressão uniaxial } \\
\text { (MPa) }\end{array}$ & $>131$ & $>52$ & $>12$ & $>34.5$ & $>69$ \\
\hline $\begin{array}{l}\text { Resistência à tração } \\
\text { na flexão (Mpa) }\end{array}$ & $>10,34$ & $<7$ & $>2,9$ & $>4,8$ & $>6,9$ \\
\hline $\begin{array}{l}\text { Resistência à flexão } \\
\text { (Mpa) }\end{array}$ & $>8,27$ & $<7$ & $x$ & $>4,8$ & $>6,9$ \\
\hline $\begin{array}{l}\text { Resistência à } \\
\text { abrasão }\end{array}$ & 25 & 10 & 10 & 10 & 10 \\
\hline
\end{tabular}

Na Tabela 5.2 (Stellin Jr. et al.,1997; Vidal et al.,2005) vemos de acordo com a aplicação, quais as características tecnológicas mais importantes que devem ser observadas e que normalmente são satisfeitas pelas especificações da Tabela 5.1.

Quando se comparam rochas ornamentais semelhantes, as características tecnológicas mais importantes para uma determinada aplicação podem ser comparadas e a escolha deve cair sobre a rocha que apresentar valores mais convenientes.

As características tecnológicas estão disponíveis nos CD-ROMs dos Institutos de Pesquisa e nos catálogos dos fornecedores.

Existem casos em que a rocha ornamental estará sujeita a condições muito severas e específicas, onde certas características devem ser analisadas ou mesmo realizadas 
experiências específicas de laboratório. Na Tabela 5.2 são denominados índices físicos a densidade aparente e a absorção d'água.

Tabela 5.2. Características tecnológicas importantes de acordo com o uso.

\begin{tabular}{|c|c|c|c|c|c|c|c|c|c|}
\hline \multirow{2}{*}{ Ensaios } & \multirow{2}{*}{$\begin{array}{c}\text { Anális } \\
\text { e } \\
\text { Petrog } \\
\text { r. }\end{array}$} & \multirow{2}{*}{\begin{tabular}{|c|} 
Índice \\
s \\
Físico \\
s (a)
\end{tabular}} & \multicolumn{4}{|c|}{ Resistência } & \multirow{2}{*}{\begin{tabular}{|l|}
$\begin{array}{c}\text { Môdulo } \\
\text { de } \\
\text { Defor- } \\
\text { mação. } \\
\text { Estático }\end{array}$ \\
Flexão
\end{tabular}} & \multirow{2}{*}{$\begin{array}{c}\text { Dilatação } \\
\text { Têrm/vs } \\
\text { Linear }\end{array}$} & \multirow{2}{*}{$\begin{array}{l}\text { Alter } \\
\text { abilid } \\
\text { a-de }\end{array}$} \\
\hline & & & Desgaste & \begin{tabular}{|l|} 
Impacto \\
\end{tabular} & $\begin{array}{c}\text { Compressão } \\
\text { Uniaxial }\end{array}$ & & & & \\
\hline Extração & $\mathrm{x}$ & $\mathrm{x}$ & $\mathrm{x}$ & & & & & $\mathrm{X}$ & \\
\hline Beneficiamento & $\mathrm{x}$ & $\mathrm{x}$ & $\mathrm{x}$ & $\mathrm{x}$ & $\mathrm{x}$ & $\mathrm{x}$ & $\mathrm{x}$ & $\mathrm{X}$ & $\mathrm{x}$ \\
\hline $\begin{array}{l}\text { Revestimento } \\
\text { Externo }\end{array}$ & $\mathrm{x}$ & $\mathrm{X}$ & $\mathrm{x}$ & & & $\mathrm{x}$ & & $\mathrm{x}$ & \\
\hline $\begin{array}{l}\text { Revestimento } \\
\text { Interno }\end{array}$ & $\mathrm{x}$ & $\mathrm{x}$ & $\mathrm{x}$ & & & $\mathrm{x}$ & & $\mathrm{x}$ & $\mathrm{x}$ \\
\hline Pisos & $\mathrm{x}$ & $\mathrm{X}$ & $\mathrm{x}$ & $\mathrm{x}$ & $\mathrm{x}$ & $\mathrm{x}$ & $\mathrm{X}$ & $\mathrm{X}$ & $\mathrm{x}$ \\
\hline Colunas e Pilares & $\mathrm{x}$ & $\mathrm{x}$ & & & $\mathrm{x}$ & $\mathrm{x}$ & $\mathrm{x}$ & $\mathrm{x}$ & $\mathrm{X}$ \\
\hline Pedestais & $\mathrm{x}$ & $\mathrm{x}$ & & & $\mathrm{x}$ & & $\mathrm{x}$ & $\mathrm{x}$ & $\mathrm{x}$ \\
\hline $\begin{array}{l}\text { Tampos de Mesas e } \\
\text { Balcões }\end{array}$ & $\mathrm{x}$ & $\mathrm{x}$ & $\mathrm{x}$ & $\mathrm{x}$ & $\mathrm{x}$ & $\mathrm{x}$ & $\mathrm{x}$ & $\mathrm{x}$ & $\mathrm{x}$ \\
\hline Pias & $\mathrm{x}$ & $\mathrm{x}$ & $\mathrm{x}$ & $\mathrm{x}$ & $\mathrm{x}$ & $\mathrm{x}$ & $\mathrm{x}$ & $\mathrm{x}$ & $\mathrm{x}$ \\
\hline Soleiras & $\mathrm{x}$ & $X$ & $\mathrm{x}$ & $\mathrm{x}$ & $\mathrm{X}$ & $\mathrm{x}$ & $\mathrm{x}$ & $\mathrm{x}$ & $\mathrm{x}$ \\
\hline Esculturas & $\mathrm{x}$ & $\mathrm{x}$ & $\mathrm{x}$ & & $\mathrm{X}$ & & $\mathrm{X}$ & $\mathrm{X}$ & $\mathrm{x}$ \\
\hline $\begin{array}{l}\text { Cilindros para } \\
\text { Indústria de } \\
\text { Alimentos, Papel, } \\
\text { etc. }\end{array}$ & $\mathrm{x}$ & $\mathrm{x}$ & $\mathrm{x}$ & $\mathrm{x}$ & $\mathrm{x}$ & $\mathrm{x}$ & $\mathrm{x}$ & $\mathrm{x}$ & $\mathrm{X}$ \\
\hline $\begin{array}{l}\text { Mesas e aparelho de } \\
\text { Desempeno }\end{array}$ & $\mathrm{X}$ & $\mathrm{X}$ & $\mathrm{X}$ & $\mathrm{X}$ & $\mathrm{X}$ & $\mathrm{X}$ & $\mathrm{X}$ & $\mathrm{X}$ & $\mathrm{X}$ \\
\hline
\end{tabular}


Com relação aos granitos pretos o que se observa é que na sua grande maioria apresentam colorações pretas e verdes de tonalidades escuras a claras e até cor branca.

Utilizando o zoom do programa Colormania é possível identificar essas cores e até comparativamente quantificá-las.

O granito Preto Absoluto apresenta a mesma cor preta visto de perto ou de longe, ao passo que os outros vistos de longe são pretos, porém de perto mostram as outras cores citadas. Disso resulta a diferença de preços entre esses materiais, sendo o granito que mais se aproxima da cor totalmente preta, o de maior valor. A Foto 5.1 ilustra o que se descreveu.

Com relação ao brilho, é possível através do uso do zoom do programa Colormania identificar o brilho leitoso dos mármores italianos em comparação com o brilho vítreo dos mármores brasileiros. Em virtude dos mármores brasileiros possuírem cristais maiores, as suas faces de reflexão não estão num mesmo plano e acabam por refletir a luz em diferentes direções.

Como a rocha ornamental tem suas cores definidas pela cor predominante, existem rochas que possuem cores mais belas em menor quantidade. Daí, recomenda-se a sua utilização em locais em que possam ser observadas de perto (lavabos, balcões, etc.), para que tenham maior realce. 


\section{CONSTRUÇÃO DO BANCO DE DADOS DAS AMOSTRAS}

A construção do Banco de Dados das amostras vai depender basicamente do tipo de usuário.Quando se tratar de um profissional liberal ou Empresa de projetos, esses Bancos de Dados podem ser simplificados e poderão conter materiais nacionais e estrangeiros e até materiais novos como pedras ornamentais. Para um produtor de matérias primas interessará apenas a apresentação dos seus produtos.Para uma Associação de Classe interessará a apresentação de maior número possível de materiais visando à divulgação dos produtos produzidos pelos seus associados.Para um comerciante interessará a apresentação de produtos de vários fornecedores nacionais ou estrangeiros com os quais mantém acordos comerciais.

O que se deve salientar é que em todas as hipóteses esses Banco de Dados podem ser feitos utilizando recursos da informática que atualmente existem em qualquer escritório.

As amostras estudadas nesta tese, tanto de mármores quanto de granitos, são nacionais. Em alguns casos serão apresentadas amostras de rochas estrangeiras. Fotos das amostras podem ser encontradas nos sites da Marbrasa, da Moredo, e nos CD-ROMs do IPT e YKK.

Os mármores e granitos foram agrupados em conjuntos de cores denominadas clássicas como normalmente se faz nas apresentações.

Na divisão por cores, sugere-se a adoção de tipos de cores dos mármores e granitos muito próximos das cores propostas. Nessa divisão citam-se os granitos movimentados, sem denominação da cor, dada a importância que têm as suas estruturas. Também, por não se enquadrarem dentro da divisão de cores clássicas proposta, são apresentados exemplos de granitos denominados (Outros).

As páginas seguintes mostram a classificação de cores propostas neste trabalho. 


\subsection{Granitos}

\section{Amarelos}
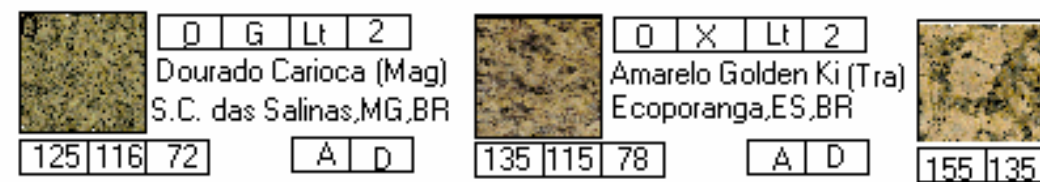

\begin{tabular}{|l|l|l|l|}
\hline 0 & $G$ & Lt & 2 \\
\hline
\end{tabular}

Giallo Venezia Fio [Gas]

\begin{tabular}{|l|l|l|l|}
\hline 125 & 116 & 72 & \\
\hline
\end{tabular}

\begin{tabular}{|l|l|l|}
\hline 135 & 115 & 78 \\
\hline
\end{tabular}

\begin{tabular}{l|l|l|l|}
\hline 155 & 135 & 87 \\
\hline
\end{tabular}

5.C. das Salinas,MG BR
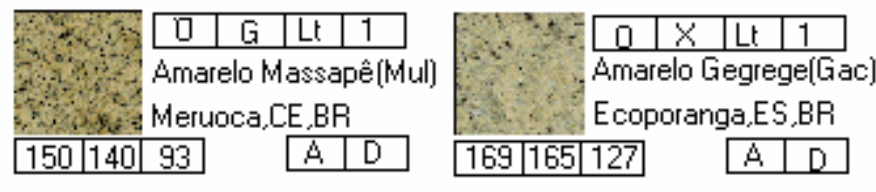

Azuis

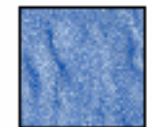

\begin{tabular}{|l|l|l|l|}
\hline $\mathrm{V}$ & $\mathrm{Co}$ & $\mathrm{Lt}$ & 10 \\
\hline
\end{tabular} Azul Macaúbas[Gimg] Macaubas,BA,BR \begin{tabular}{|l|l|l|l|}
\hline 108 & 145 & 195 \\
\hline
\end{tabular}

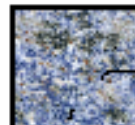

\begin{tabular}{|l|l|l|l|}
\hline$V$ & $G$ & Lt & 7 \\
\hline
\end{tabular} Potiragua,BA,BR

\begin{tabular}{|l|l|l|}
\hline 134 & 144 & 163 \\
\hline
\end{tabular}

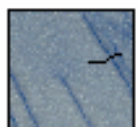

\begin{tabular}{|l|l|l|l|}
\hline $\mathrm{V}$ & $\mathrm{Co}$ & $\mathrm{Lt}$ & 8 \\
\hline
\end{tabular}

Azul Boquira (Mam) Macaubas,BA,BR

\section{Brancos}

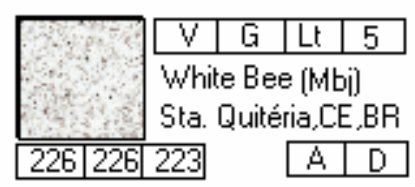

\section{2} Sta. Quitéria CE BR \begin{tabular}{|l|l|l|}
\hline 215 & 218 & 204 \\
\hline
\end{tabular}
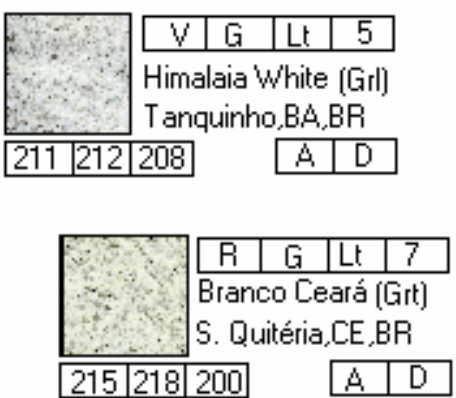
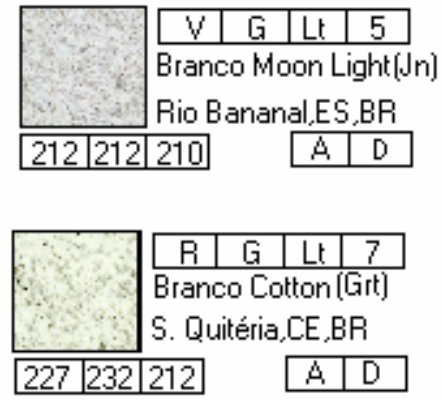


\section{Cinzas}
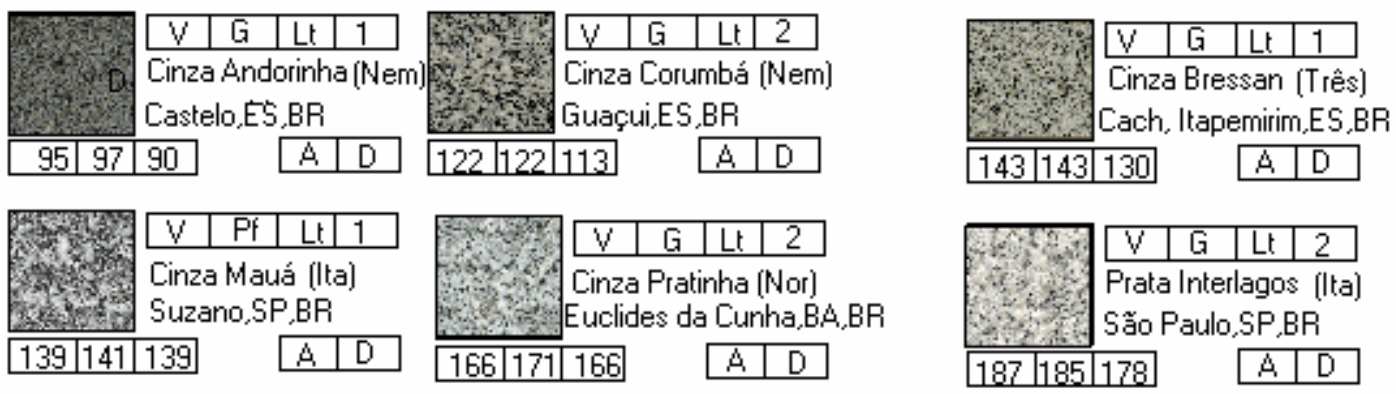

\section{Marrons}

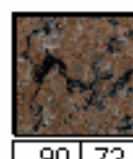

\begin{tabular}{|l|l|l|l|}
\hline$V$ & $G$ & Lt & 3 \\
\hline
\end{tabular}

Marrom Fantasia [Jn] Nova Venecia,ES,BR
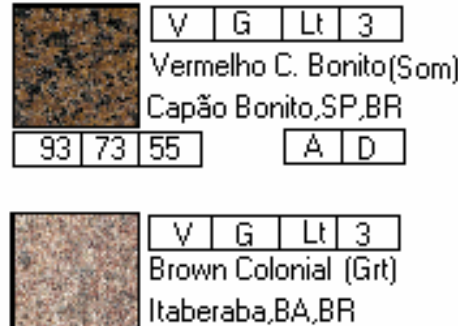

\begin{tabular}{|l|l|l|l|}
\hline$V$ & $G$ & $\mathrm{Lt}$ & 3 \\
\hline
\end{tabular} Brown Colonial [Gritt] Itaberaba,BA,BR

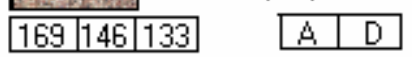

Movimentados

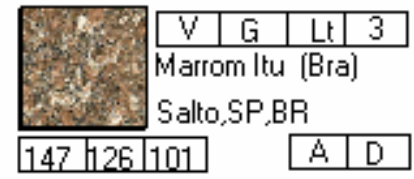

\begin{tabular}{ll|l|l|}
\hline 147 & 126 & 101 \\
\hline
\end{tabular}

\begin{tabular}{|l|l|}
\hline$A$ & $D$ \\
\hline
\end{tabular}
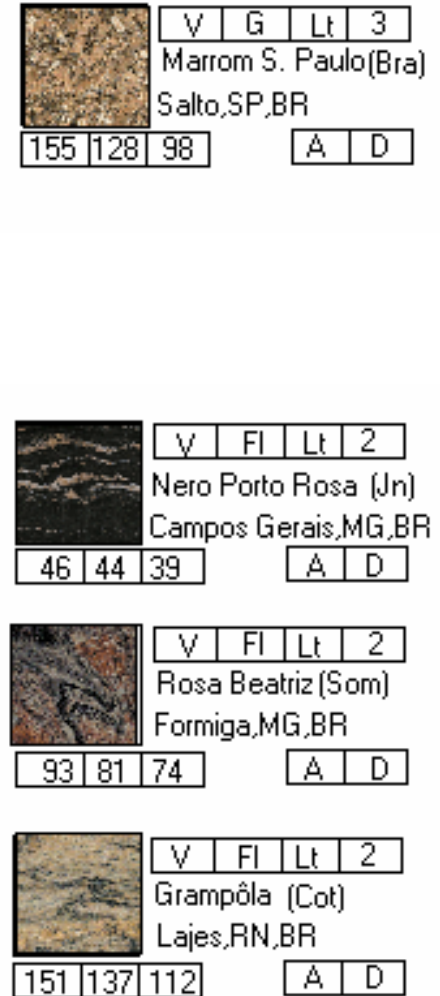
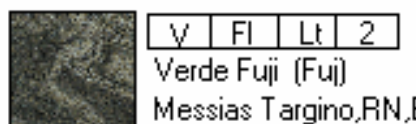

Messias Targino,RN,BR
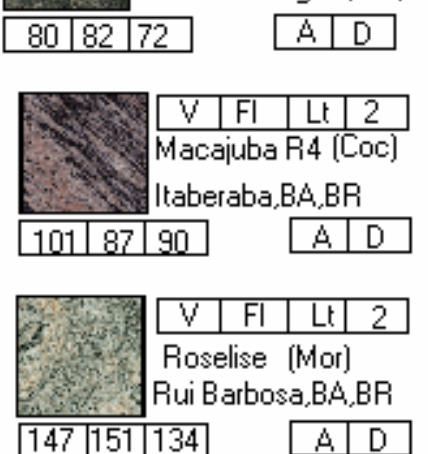
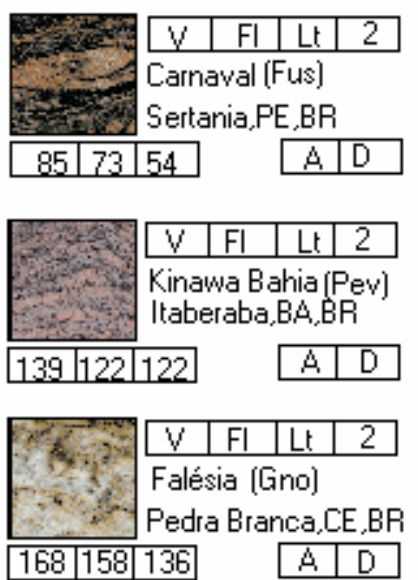
Pretos
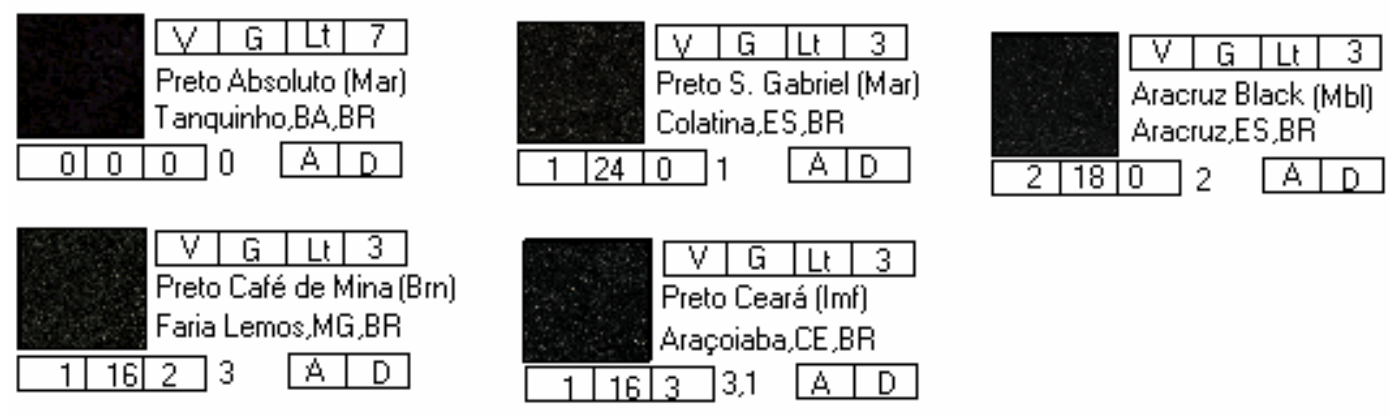

\section{Rosas}
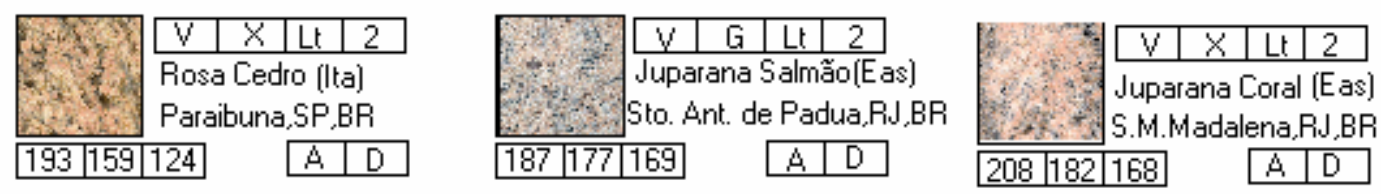

\section{Verdes}
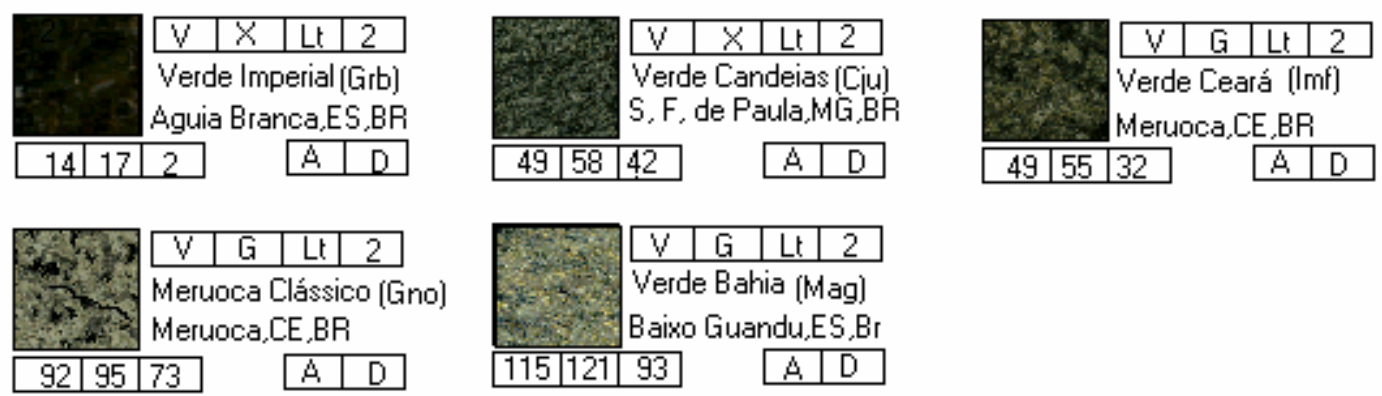
Vermelhos

\begin{tabular}{|c|c|c|c|c|}
\hline & $\mathrm{V}$ & $\mathrm{G}$ & $\mathrm{Lt}$ & 4 \\
\hline & \multicolumn{4}{|c|}{$\begin{array}{l}\text { New Rubin } \\
\text { India }\end{array}$} \\
\hline \multirow[t]{4}{*}{\begin{tabular}{|l|l|}
107 & 45 \\
\end{tabular}} & 36 & & & D \\
\hline & V & $G$ & $\mathrm{Lt}$ & 3 \\
\hline & Red & itóric & Mo & \\
\hline & Tano & inho & $3 \mathrm{~A}, \mathrm{~B}$ & \\
\hline \begin{tabular}{|l|l|}
189 & 147 \\
\end{tabular} & 131 & & $\mathrm{~A}$ & $\mathrm{D}$ \\
\hline
\end{tabular}
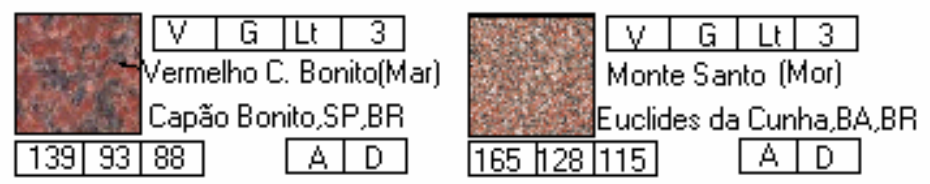

Outros
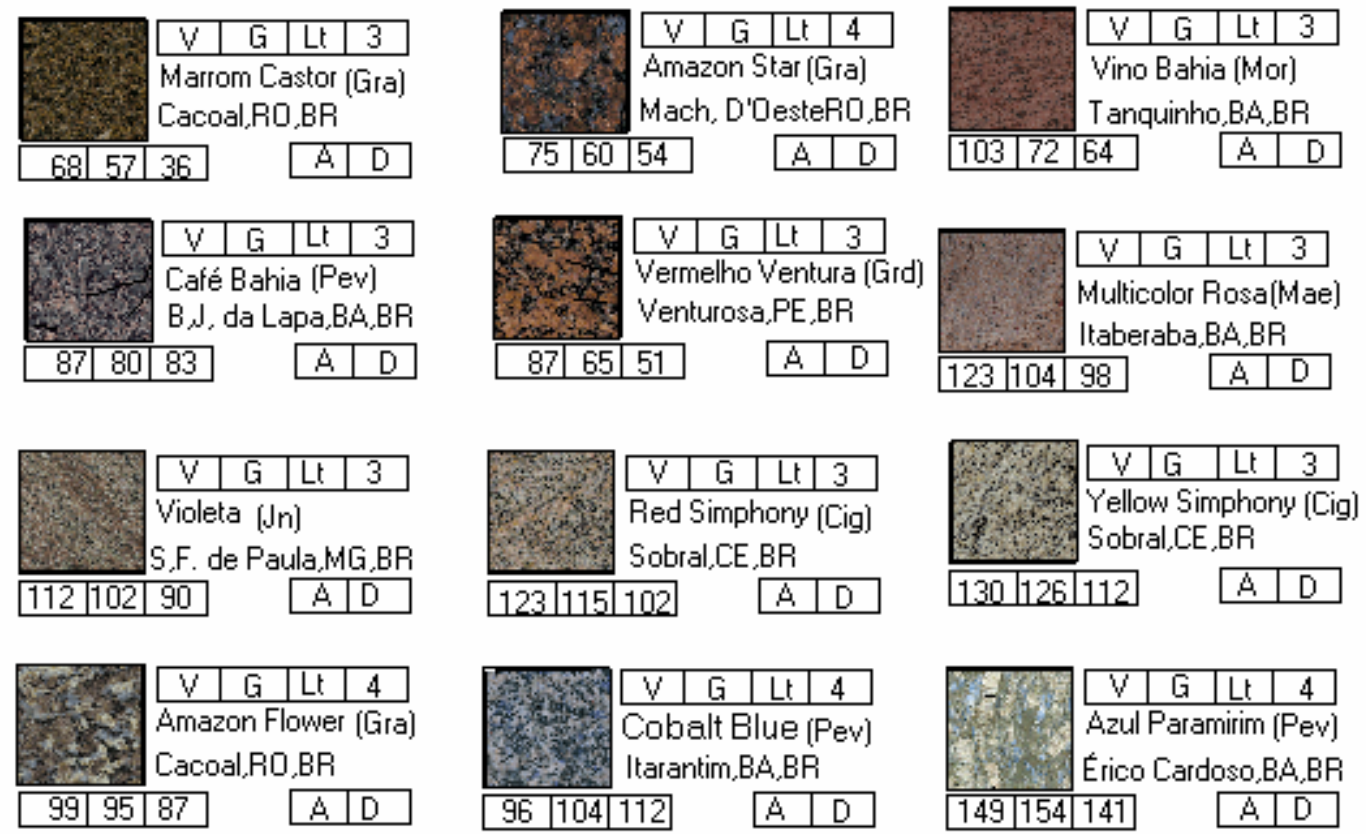


\subsection{Mármore}

Beges e Cremes

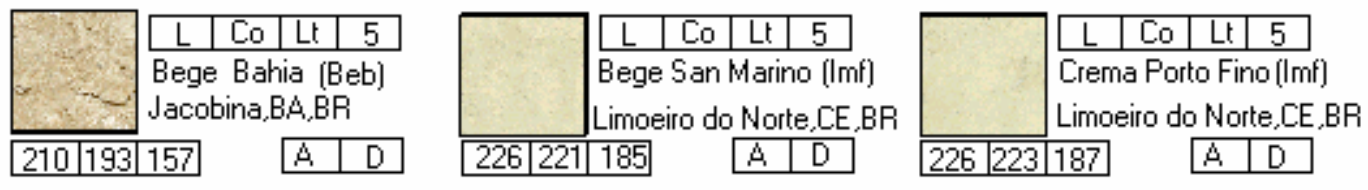

Brancos
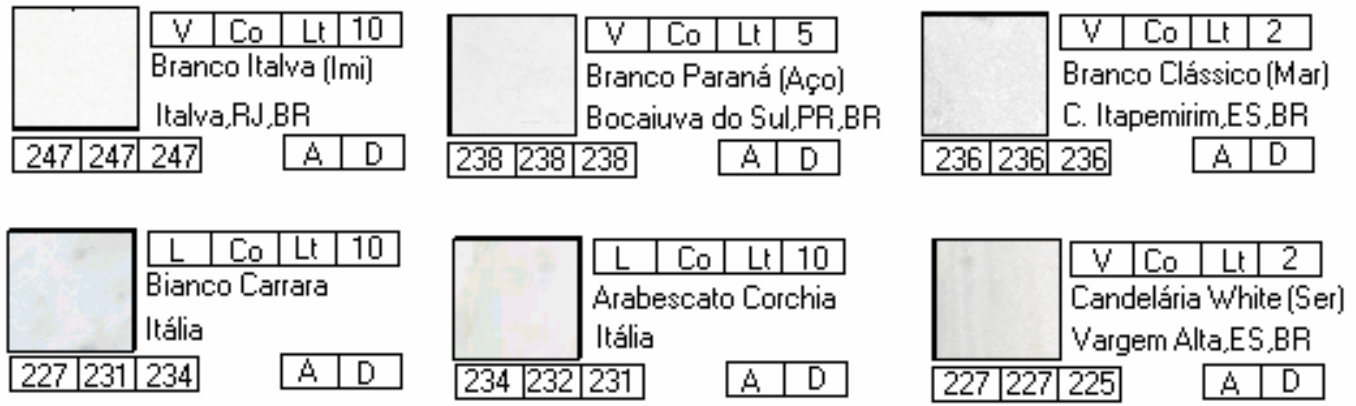

\section{Marrons}
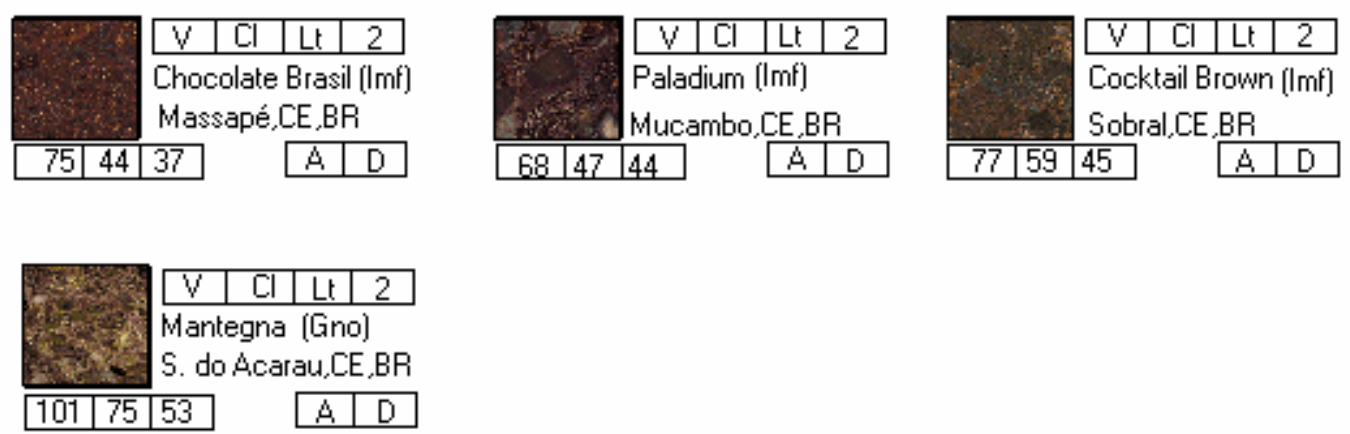
Pretos

\begin{tabular}{|c|c|c|c|c|}
\hline & $\mathrm{V}$ & $\mathrm{Co}$ & $\mathrm{Lt}$ & 10 \\
\hline & \multicolumn{4}{|c|}{$\begin{array}{l}\text { Nero Marquina } \\
\text { Espanha }\end{array}$} \\
\hline \begin{tabular}{l|l}
17 & 20 \\
\end{tabular} & 21 & & $\mathrm{~A}$ & D \\
\hline
\end{tabular}

Rosas

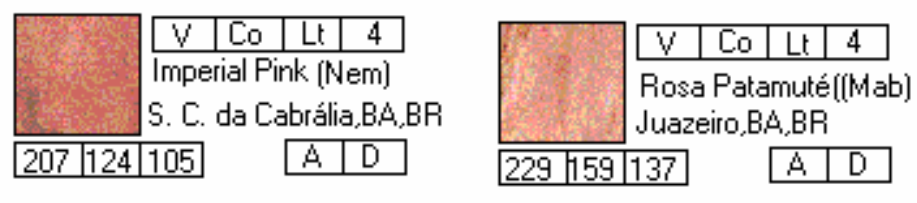

Verdes
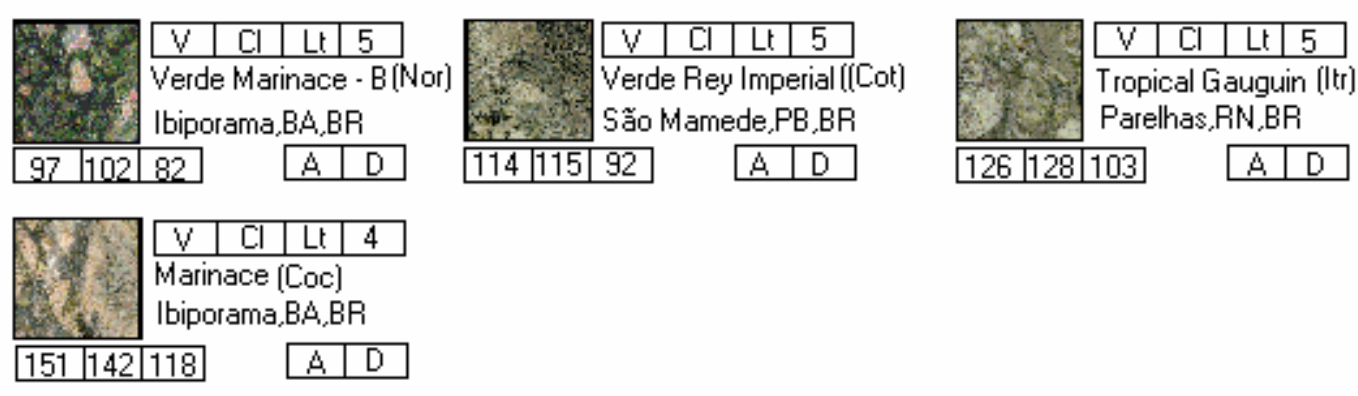


\section{Vermelhos}

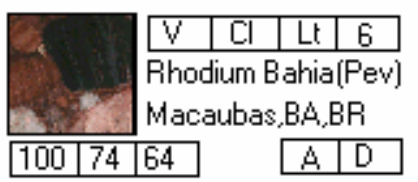

Os programas de combinações de cores permitem realizar a escolha entre cores de materiais de várias naturezas. No caso das tintas é possível obter com facilidade as cores desejadas.

Quando se tratar de materiais naturais deve-se escolher entre as cores disponíveis. Assim, nos mármores e granitos quando não se encontrarem no Banco de Dados nas cores desejadas, deve-se consultar as várias fontes disponíveis e, mediante o uso de programa de identificação de cores, escolher a cor que mais se aproxima daquela que se pretende.

No caso do exemplo de aplicação do próximo capítulo, além dos programas de informática já citados, será utilizado o programa Gimp 2.1 encontrado no PC Expert (2004). Esse programa trabalha com o sistema RGB e pode aplicar cores e texturas em qualquer área do desenho. 


\section{EXEMPLO DE APLICAÇÃO}

Escolheu-se um tipo de intervenção arquitetônica que será considerado como exemplo, adotando o procedimento mais conveniente e utilizando o Banco de Dados que foi construído no Capítulo 6.

1) Foram escolhidas as cores principais das rochas ornamentais de acordo com o esquema decorativo apresentado no Capítulo 4, páginas 49 a 52 e determinaram-se seus valores RGB, no Banco de Dados.

2) Através do programa ColorMania, que contém as cores combináveis, foram escolhidas as cores que combinam com a cor principal e que obedecem ao esquema decorativo, na possibilidade de serem utilizados outros tipos de rochas ornamentais na mesma intervenção arquitetônica. Foram determinados os valores RGB das cores combináveis.

3) Utilizou-se a Tabela 7.1 numa primeira escolha das cores dos granitos semelhantes às cores combináveis.

4) Usando-se o programa ColorMania, verificou-se a semelhança entre as cores.

5) Escolhidas as rochas, verificou-se a possibilidade de aplicação do ponto de vista tecnológico.

6) Elaborou-se um exemplo de intervenção arquitetônica.

Utilizando os valores RGB de cada rocha do Banco de Dados, sugere-se a criação de quatro critérios que poderão auxiliar na escolha das cores das rochas. São eles:

1) quatro grupos de cores das rochas

Grupo A - as diferenças (R-G) e (G-B) são positivas (+,+).

Grupo B - as diferenças (R-G) e (G-B) são negativas (-,-).

Grupo C - as diferenças (R-G) e (G-B) são nulas ou negativas e positivas $(0,0) \quad(-,+)$. 
Grupo D - as diferenças (R-G) e (G-B) são nulas e negativas, negativas e positivas, negativas e negativas e positivas e positivas $(0,-)(-,+)(-,-)(+,+)$.

2) faixa de variação dos valores de R, para cada grupo de cores.

3) faixa de variação dos valores absolutos de (R-G) para cada grupo de cores.

4) faixa de variação dos valores absolutos de (G-B) para cada grupo de cores.

Segundo esses critérios, teremos para as cores das rochas os valores indicados na Tabela 7.1 .

Tabela 7.1 Tabela de cores e respectivos valores de R, R-G, G-B e RGB em percentagem.

\begin{tabular}{|l|c|c|c|c|c|}
\hline \multicolumn{1}{|c|}{ Cor } & Grupo & R & R-G & G-B & Valores RGB em \% \\
\hline Amarela & A & $125-169$ & $004-020$ & $037-044$ & $36-40,35-37,23-27$ \\
\hline Azul & B & $108-134$ & $010-037$ & $015-050$ & $24-30,32-33,37-43$ \\
\hline Branca & D & $211-232$ & $000-003$ & $002-020$ & $33-34,33-34,32-33$ \\
\hline Cinza & D & $095-187$ & $000-005$ & $003-013$ & $33-34,33-34,31-33$ \\
\hline Marrom & A & $090-169$ & $017-027$ & $012-025$ & $34-42,32-33,24-27$ \\
\hline Preta & C & $000-017$ & $000-023$ & $000-024$ & $04-33,33-96,00-10$ \\
\hline Rosa & A & $187-208$ & $010-034$ & $008-035$ & $35-40,33-37,26-31$ \\
\hline Verde & B & $210-226$ & $003-007$ & $036-036$ & $35-37,34-35,28-29$. \\
& & & & & \\
\hline
\end{tabular}


Pretende-se, no exercício, realizar uma intervenção arquitetônica num piso interno ou em parte dele, que reflita um ambiente tranqüilo, obedecendo aos critérios propostos no Capitulo 4. Escolheu-se um desenho clássico denominado Corolla, proposto por Corbella (1998), onde serão aplicados o mármore Branco Italva, o granito azul Macaúbas e um segundo tipo de granito cuja cor seja combinável com a cor azul do granito Macaúbas. Todos esses tipos de mármores e granitos encontram-se no Banco de Dados.

Utilizando o programa ColorMania determinou-se as cores combináveis com a cor do granito Macaúbas e seus respectivos valores de RGB. Os valores encontrados, foram: granito azul Macaúbas $(108,145,195)$ e os restantes, em número de cinco : $(56,60,56)$, $(80,104,136)$, $(72,76,136)$, $(72,128,136)$ e $(16,32,72)$. Em seguida passou-se a escolha dos granitos cujas cores fossem semelhantes às cores combináveis.

1) $\operatorname{RGB}(56,60,56) \quad \mathrm{R}=56 ; \mathrm{R}-\mathrm{G}=-4$ e $\mathrm{G}-\mathrm{B}=+4 . \quad(-,+)$

2) $\operatorname{RGB}(80,104,136) \mathrm{R}=80 ; \mathrm{R}-\mathrm{G}=-24$ e $\mathrm{G}-\mathrm{B}=-32 \quad(-,-)$

3) $\operatorname{RGB}(72,76,136) \quad \mathrm{R}=72$; R-G = - 4 e $\mathrm{G}-\mathrm{B}=-60 \quad(-,-)$

4) $\operatorname{RGB}(72,128,136) \mathrm{R}=72 ; \mathrm{R}-\mathrm{G}=-56$ e $\mathrm{G}-\mathrm{B}=-18 \quad(-,-)$

5) $\operatorname{RGB}(16,32,72) \quad \mathrm{R}=16 ; \mathrm{R}-\mathrm{G}=-16$ e $\mathrm{G}-\mathrm{B}=-40 \quad(-,-)$

Segundo os critérios sugeridos na pág. 80, a cor combinável 1 pertence ao grupo C (preto ou verde) ou D (branco ou cinza) e as cores combináveis de 2 a 5 pertencem ao grupo B (azul, bege ou creme) e Grupo D (branco ou cinza).

A cores branca e azul já foram escolhidas e as cores bege, creme, cinza e preto apresentam na Tabela 7.1 e no Banco de Dados, valores de RGB muito diferentes das cores combináveis.

Portanto, com relação às rochas cujos valores RGB mais se aproximam da cor combinável 1, RGB $(56,60,56)$ são as cores verdes do granito Verde Ceará, RGB $(49,43,50)$,e do granito Verde Candeias, RGB (49,58,42), existentes no Banco de Dados. 
Utilizando-se o programa ColorMania, verificou-se que as cores verdes escuras do granito Verde Ceará e do granito Verde Candeias apresentam visualmente uma diferença imperceptível com relação à cor combinável 1 , enquanto que as cores dos outros granitos verdes existentes no Banco de Dados apresentam cor verde mais clara ou mais escura. Escolheu-se o granito Verde Ceará como combinável com o granito Azul Macaúbas.

Consultando-se as Tabelas 5.1 e 5.2, quanto ao tipo de aplicação e as características tecnológicas das rochas ornamentais utilizadas na intervenção, conclui-se pela suas aplicações. As características tecnológicas das rochas utilizadas foram obtidas do Instituto de Pesquisas Tecnológicas do Estado de São Paulo(2001).

Utilizando o programa Gimp 1.2 da PC Expert (2004) colocou-se os padrões das rochas no desenho Corolla, cujo resultado encontra-se na Fig.7.1.

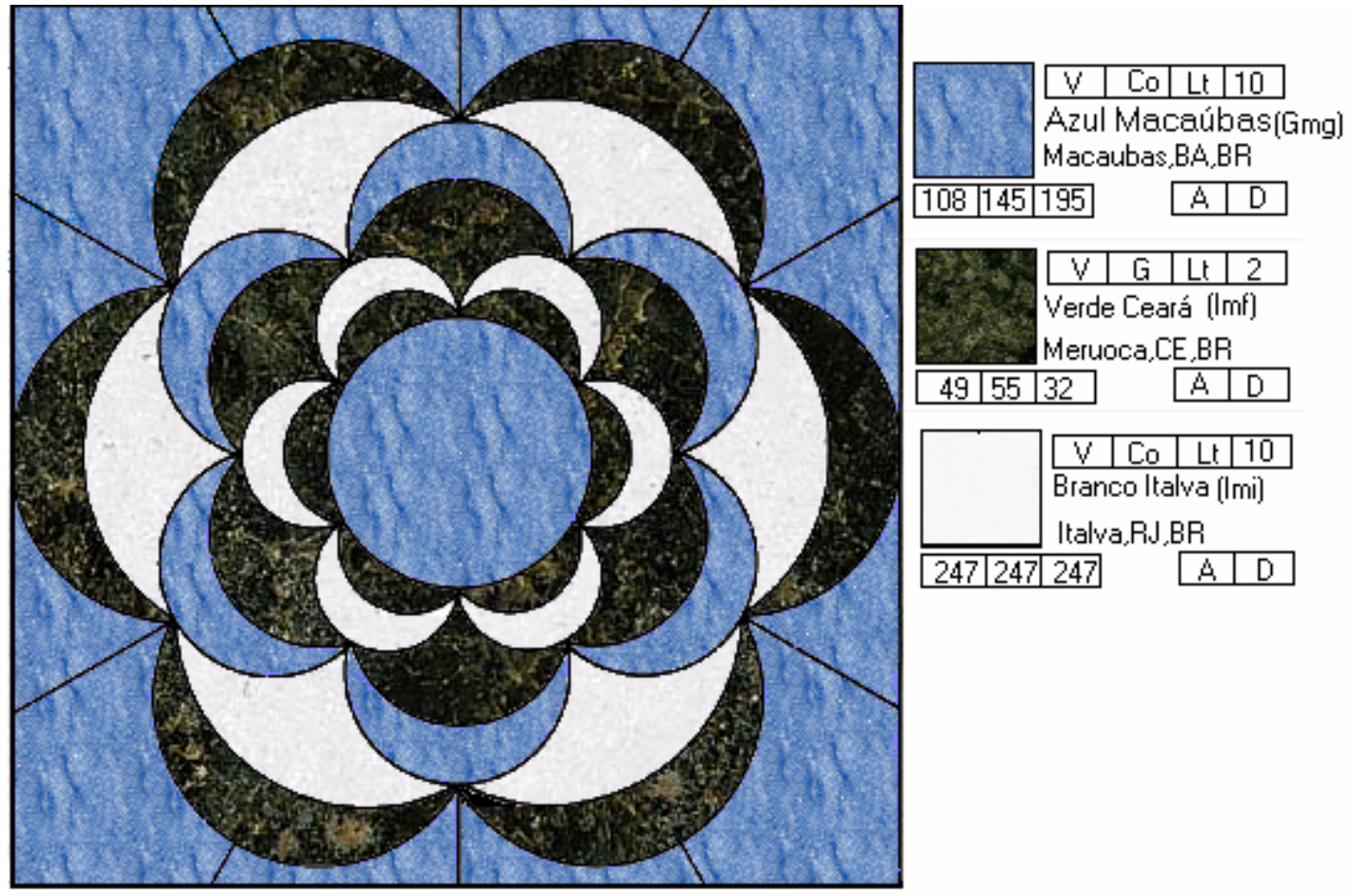

Fig. 7.1 Intervenção arquitetônica. 


\section{CONCLUSÕES}

É de fundamental importância o conhecimento da gênese das jazidas, bem como a mineralogia e a estrutura das rochas ornamentais.

Num projeto de média ou de grandes dimensões sugere-se que o projetista verifique junto às pedreiras os padrões e os volumes de rocha disponíveis.

No caso de pequenas obras é possível verificar o padrão e a quantidade das chapas ou placas a serem adquiridas junto aos fornecedores.

É de fundamental importância verificar durante o projeto de colocação se o material será visto pelas pessoas numa distância afastada ou próxima.

Atentar para o tipo de sensação que se deseja causar nas pessoas para escolha da cor e estrutura do material lapídeo.

Foram indicados vários recursos que podem ser utilizados para a escolha da cor de uma rocha ornamental como os sistemas RGB e RCC.

O sistema RGB se mostrou o mais prático e mais preciso na escolha das cores das rochas ornamentais, diante dos vários recursos apresentados.

A definição de cor deixa de ser subjetiva e passa a ser objetiva através do uso da classificação RGB.

De acordo com o trabalho desenvolvido, qualquer pessoa dispondo de recursos mínimos de informática poderá construir um Banco de Dados de rochas ornamentais que lhe for conveniente. 
O Banco de Dados da forma proposta é uma fonte de consulta rápida e objetiva que contém as informações mais importantes para o desenvolvimento dos projetos de intervenções arquitetônica.

Foi sugerido um procedimento a ser seguido nos projetos e se desenvolve um exercício como exemplo de intervenção arquitetônica. 


\section{LISTA DE REFERÊNCIAS}

ABCDICAS (Ed.) Cores combináveis. Disponível em: < http://www.abcdicas.com.br >.Acesso em: 22/fev./2004.

ALMEIDA, S.L.M. Aproveitamento de rejeitos de pedreiras de Santo Antonio de Pádua, RJ, para a produção de brita e areia. 2001.118 p. Tese (Doutorado) - Escola Politécnica, Universidade de São Paulo, São Paulo, 2001.

BLACKSUN SOFTWARE (Ed.) Colormania. Disponível em: < http:// www.blacksun.3ts.be > Acesso em: 18/mar./2004.

BLANCO, G. Le pietri ornamentali in architectura. $1^{\mathrm{a}}$ ed. Roma: La Nuova Itália Scientifica, $1993.147 \mathrm{p}$.

BRADLEY, F. Guida alla scelta delle rocce ornamentali in architettura. Milão: Technostone, $1998.32 \mathrm{p}$.

CAMI, J.T.; SANTAMERA, J.C. A escultura em pedra. $1^{\text {a }}$.ed.Lisboa: Editorial Estampa Ltda., 2001.174 p.

CANAVESIO, G. Façade cladding - Tecnological design.Local Milão: Marmomacchine International, n.19, p.44-63,1977.

Marmi, graniti, travertini, e pietri, indicazioni per la scelta e l'impiego in edilizia. Milão: Borsa Marmi, n. 137, p.66-73,1991.

CARANASSIOS, A; STELLIN JR. A. A extração de rochas ornamentais. São Paulo: Revista Brasil Mineral, n. 89, p.30-34,1991.

CAVALCANTI, A.M.S. Tecnologia da pedra. 1951.309 p. Tese (Livre Docência)-

Escola Nacional de Engenharia, Universidade do Brasil, Rio de Janeiro, 1951.

CORBELLA, E.(Ed.) Manuale dei marmi, pietre e graniti.Milano: 1998.1 CD-ROM. 
COSMIN SOFTWARE (Ed.) Color detector. Disponivel em: < http:// www.cosmin.com >.Acesso em: 20/ag./ 2004.

DICAS DE DECORAÇÃO. São Paulo: Persianas Luxaflex. Disponível em : < http://persianasluxaflex.com.br >.Acesso em: 23/nov./2004.

DIPLODOCK (Ed.) Color pick Pro 1.0 Disponível em : <http://www.diplodock.com> . Acesso em : 09/mar./2004.

FERNANDES, P. Cores: onde, como e quando usa-las. São Paulo: [s.n.]. Disponível em: < http://cliente.argo.com.br.>.Acesso em: 09/nov. /2004.

FILIPOV, M. Aplicação de métodos computacionais no planejamento para extração de rocha ornamental em maciço rochoso. 2002.145 p. Dissertação (Mestrado)-Escola Politécnica, Universidade de São Paulo, São Paulo, 2002.

GODDARD, E. N. Rock Colour Chart. New York: Geological Society of America, 1951.18 p.

HENNIES, W.T.; STELLIN JR, A. Contribution to the study of cutting mechanism of Capão Bonito granite, São Paulo, Brazil. In: INTERNATIONAL SYMPOSIUM ON MINE PLANNING AND EQUIPMENT SELECTION, Athens,2000,Rotterdam,Balkema, 2000. p.573-576

INSTITUTO DE PESQUISAS TECNOLÓGICAS DO ESTADO DE SÃO PAULO A cadeia produtiva de rochas ornamentais para revestimento no Estado de São Paulo, Publicação IPT 2995,2004. 191 p.

• Catálogo de rochas ornamentais do Brasil.São Paulo: 2001. 1 CD-ROM ISTITUTO NAZIONALE COMMERCIO ESTERO. Marmi italiani - Guida Técnica. Milano: Vallardi Editori,1982.238 p. 
KUZIN, M; EGAROV, N. Field Manual of minerals . Moscow: Mir Publishers, 1979. $194 \mathrm{p}$.

LEINZ, V. Guia para determinação de minerais. $5^{\mathrm{a}}$.ed. São Paulo: Nacional/Edusp, 1971.68 p.

MASTRELLA, R; STELLIN, M.R; DE TOMI, G.F.C. - Avanços tecnológicos no planejamento de lavra para rochas ornamentais - In: II Seminário de Rochas Ornamentais do Nordeste, Salvador, 2001, Anais. Rio de Janeiro: CETEM, 2001. p. 78-81.

MATTOS, M.A. Processamento de imagens. São Paulo: [s.n.] Disponível em: < http: //usuarios.Skydome.Net > .Acesso em: 23/nov. /2004.

MECÂNICA GERAL E MÁQUINAS LTDA. Catálogo comercial. São Paulo: 2004.23p.

MELLO MENDES, F. Condicionalismo e problemas da indústria das pedras de construção e ornamentais. Luanda: Universidade de Luanda, 1974. 68 p.

MOTOKI, A.; NEVES, J.L.P.; VARGAS, T. Quantitative colour analyses using digital specification technique for Mármore Bege Bahia, a representative ornamental limestone of breccia-like texture. Ouro Preto: Revista Escola de Minas de Ouro Preto, v.58, n.2, p.113-120, 2005.

MUNSELL, A.H. A color notation. Londres: Munsell Color Company Inc., 1947.74 p.

Pauta para preços mínimos de mármores e granitos. Diário Oficial do Estado do Espírito Santo, Vitória, 01 abr. 2004. p.103.

PC EXPERT (Ed.) Gimp 1.2. São Paulo: 2004.1 CD-ROM. 
PEARL, R.M. How to know the minerals and rocks. São Paulo: Mac Graw Hill Paperbacks, $1955.192 \mathrm{p}$.

PELLEGRINI MACHINE. Catálogo comercial, Verona: 2001.36 p.

PONTES, I.F. Aproveitamento de finos gerados na serragem de mármores e granitos. 2001.150 p. Tese ( Doutorado ) - Escola Politécnica,Universidade de São Paulo, São Paulo,2.001.

RIBEIRO,M. Planejamento visual gráfico. $2^{\mathrm{a}}$.ed. Brasília: Linha Gráfica e Editora, 1987.464 p.

RUFFA, N; NICOLI, R. Il colore dei materiali - Una proposta di valutazione. Milão: Marmomacchine n.130, p.58-80,1998.

SILVERAGE SOFTWARE (Ed.) Color spy 1.01. Disponível em :

<http://www.silveragesoftware.com $>$. Acesso em :12/set./2004.

SINDICATO DE MÁRMORES E GRANITOS DO ESTADO DE SÃO PAULO

Conheça Mármores e Granitos.São Paulo: Publ. 28, 2000. 18 p.

STELLIN JR, A; SANSONE, E.C; HENNIES, W.T. Relatório Técnico da Escola Politécnica, Universidade de São Paulo, Departamento de Engenharia de Minas, Processo 95/5067-6, São Paulo: EPUSP,1997. 57 p.

STELLIN JR., A. Serragem de granitos para fins ornamentais. Boletim Técnico da Escola Politécnica, Universidade de São Paulo, Departamento de Engenharia de Minas, BT/PMI/085, São Paulo: EPUSP, 1998.35p.

STELLIN, M.R. Planejamento de serragem de rochas ornamentais. 2003.61p.

Dissertação (Mestrado)- Escola Politécnica, Universidade de São Paulo, São Paulo, 2003. 
TRAVIS, R.B. Classification of Rocks . Golden: Quarterly of the Colorado Scholl of Mines, v. 50, n. 1, 1955. 98 p.

TYRRELL, G.W. The Principles of Petrology. Londres: Methuen \& Co. Ltd.,1956.349 p.

VIANELLO, F. Il reconoscimento dei materiali lapidei (I parte). Local Milão: Marmomacchine n. 126, p.192-206,1995.

Marmomacchine n.127, p.186-202,1995.

VIDAL, F.W.H. Estudos dos elementos abrasivos de fios diamantados para lavra de granito do Ceará. 1999.173 p. Tese (Doutorado)- Escola Politécnica , Universidade de São Paulo, São Paulo,1999.

VIDAL, F.W.H; SALES, F.A.C.B; ROBERTO, F.A.C. Rochas Ornamentais e de Revestimentos. In: Rochas e Minerais Industriais do Estado do Ceará. Fortaleza: CETEM/UECE/DNPM/FUNCAP/SENAI, 2005. p.26-47.

VIDAL, F.W.H; BESSA, M.F; LIMA, M.A.B Avaliação de Rochas Ornamentais do Ceará através de suas Características Tecnológicas. Rio de Janeiro: CETEM/MCT, 1999. $56 \mathrm{p}$.

WILLIAMS, H.; TURNER, F.J.; GILBERT, C.M. Petrografia . São Paulo: Editora Poligono, 1976. $441 \mathrm{p}$.

WINKLER, E.M. Stones: properties, durability in man's environment. Wien: Springer- Verlag, 1973. $230 \mathrm{p}$. 


\section{BIBLIOGRAFIA}

CONCI, A.(Ed.) Digital Image Processing 1.0.London: 2002. 1 CD-ROM.

KENNARD, T.G.; HOWELL, D.H. Types of coloring in minerals.Londres: The American Mineralogist, v. 26, n.7, p. 405-421,1976.

MOL-GRANITOS DO BRASIL (Ed.) The International Diretory of Natural Stones

Factory.Disponível em:< http:// www.tilefinder.com.Br> .Acesso em: 23/jun./2005.

PEITER, C.C; CHIODI FILHO, C. Rochas ornamentais no século XXI. Rio de Janeiro: CETEM/ABIROCHAS, $2001.128 \mathrm{p}$.

PÉREZ, B.J. Avanços e transferência tecnológica em rocha ornamental.Rio de Janeiro: CETEM/MCT, 2001.200 p.

TEORIA DA COR. São Carlos: Universidade Federal de São Carlos.Disponível em: $<$ http://www.arq.ufsc.br/labcon/arq5661/cores/html > Acesso em : 22/jun./2005

TEORIA DAS CORES. [S.I.:s.n.] Disponível em: < http://www.espaçofotográfico.com.br.> . Acesso em: 11/out. /2005. 


\section{Anexo A}

Tabelas de cores das rochas segundo GODDARD (1951) 


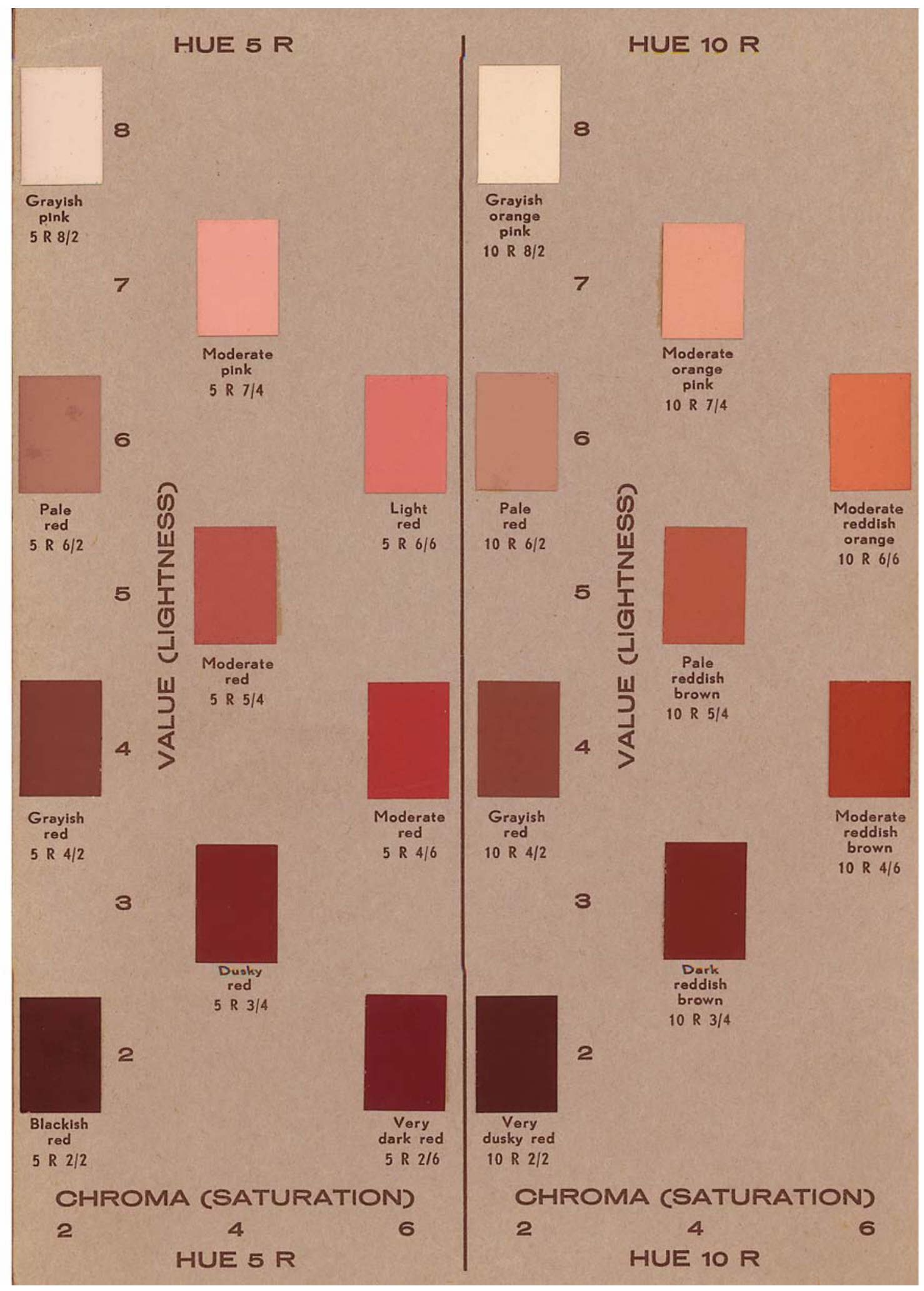




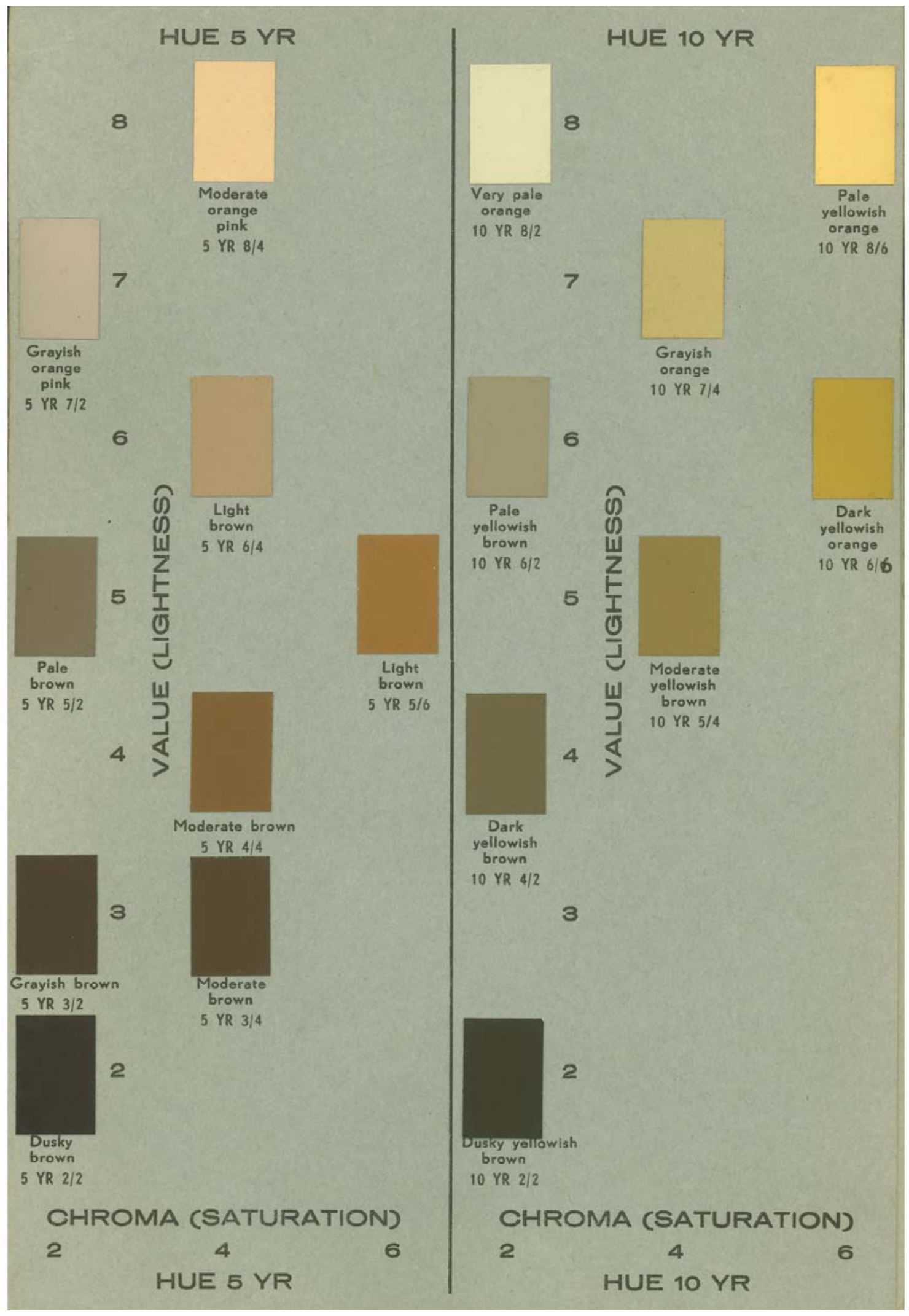




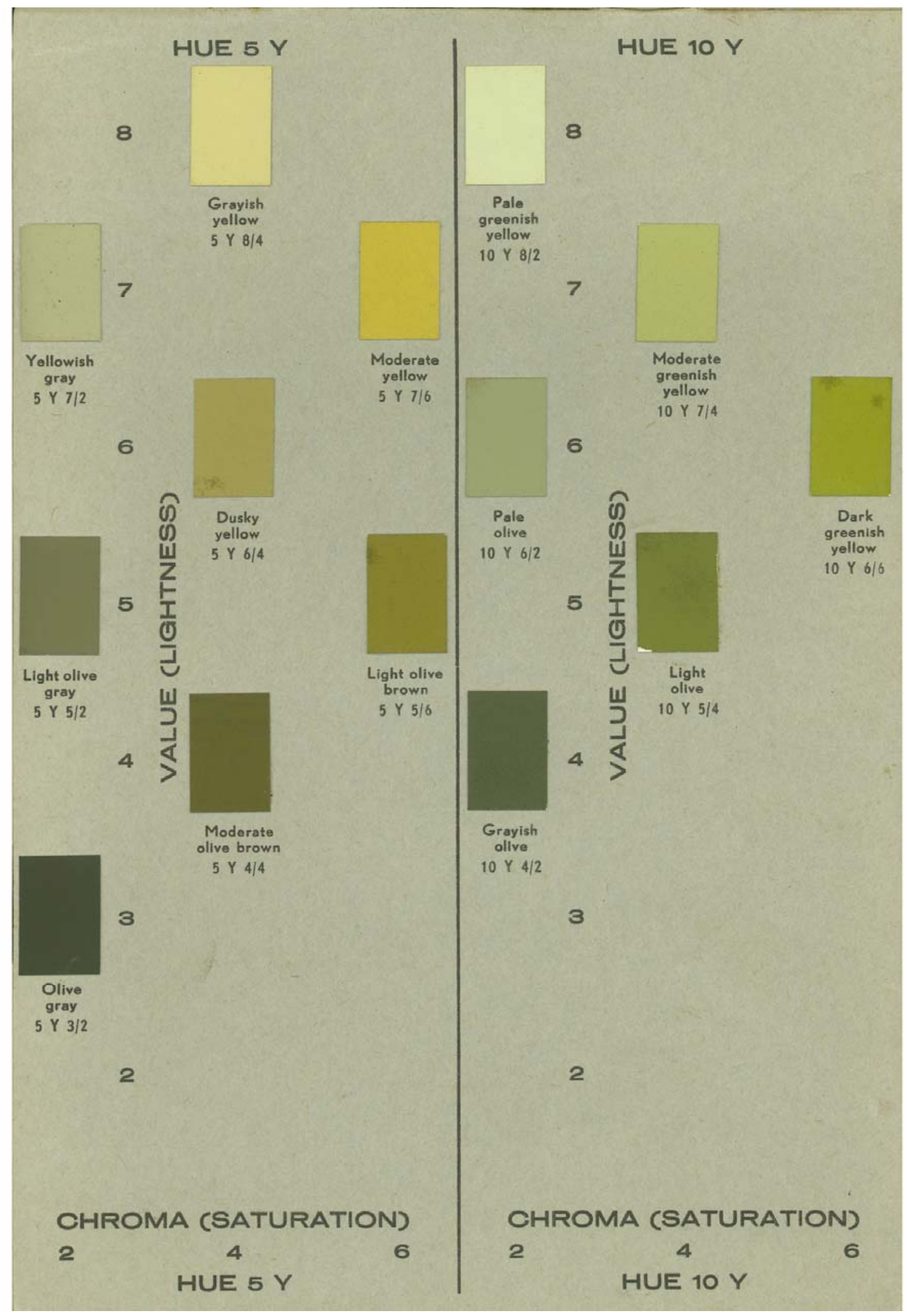




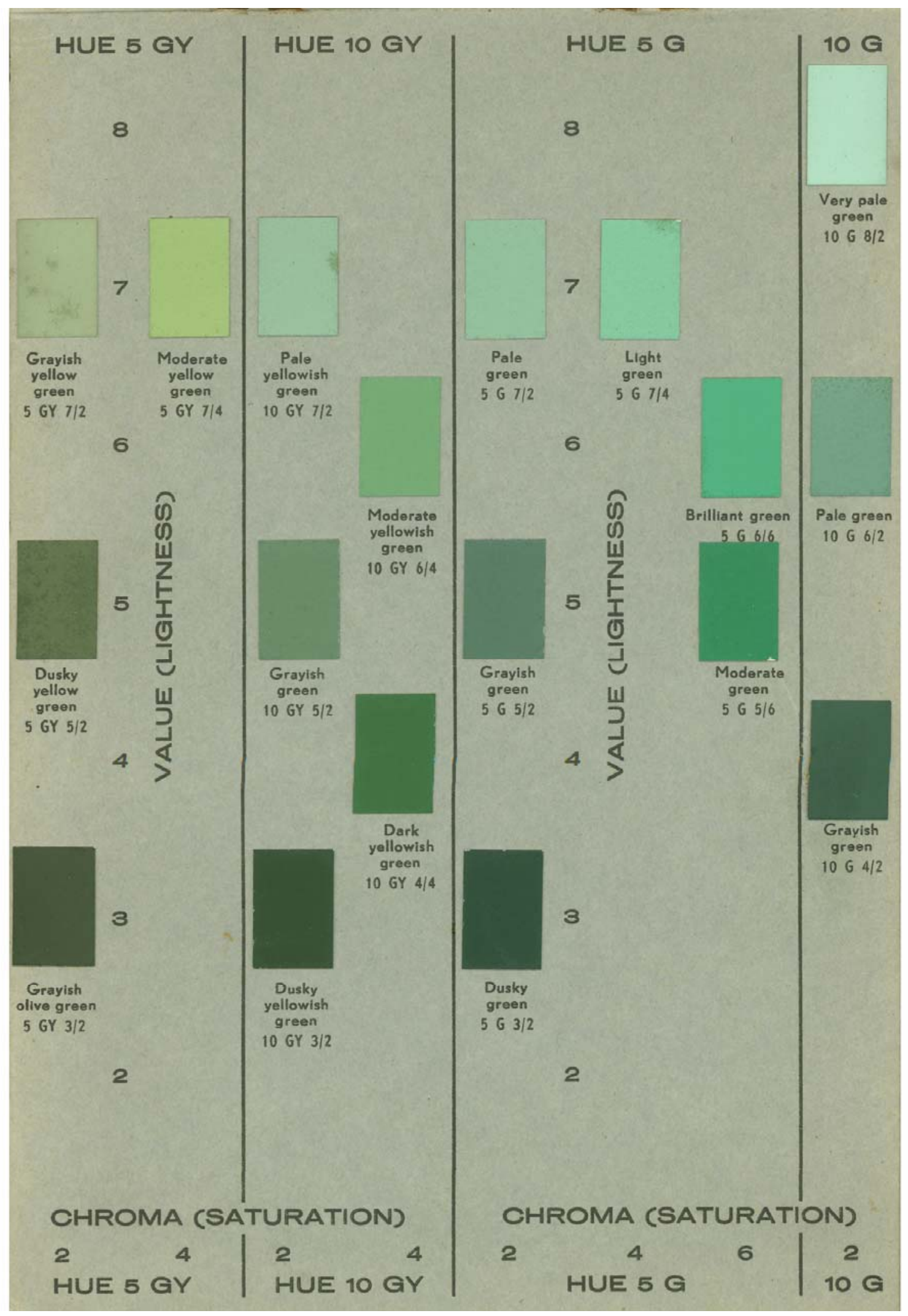




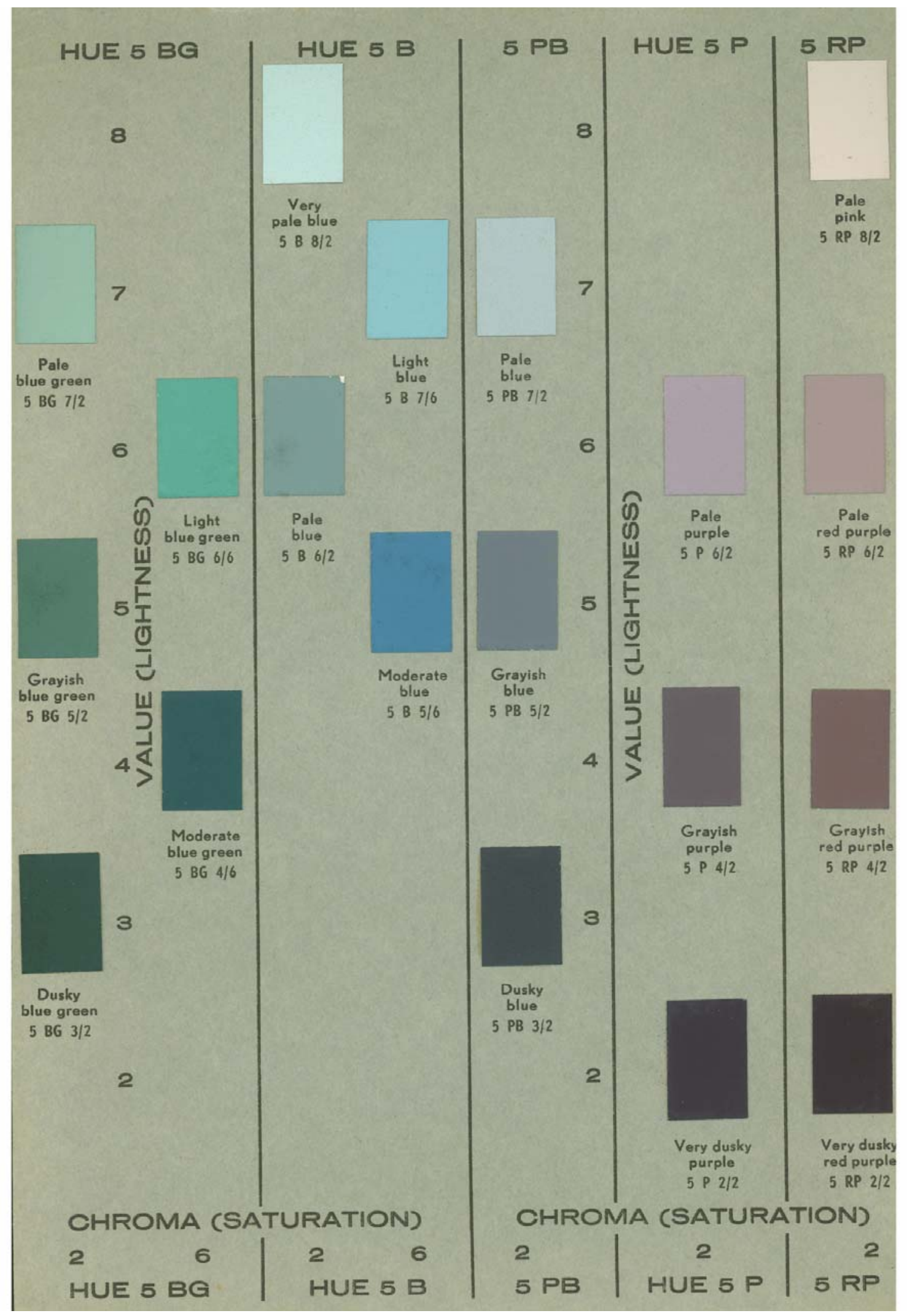




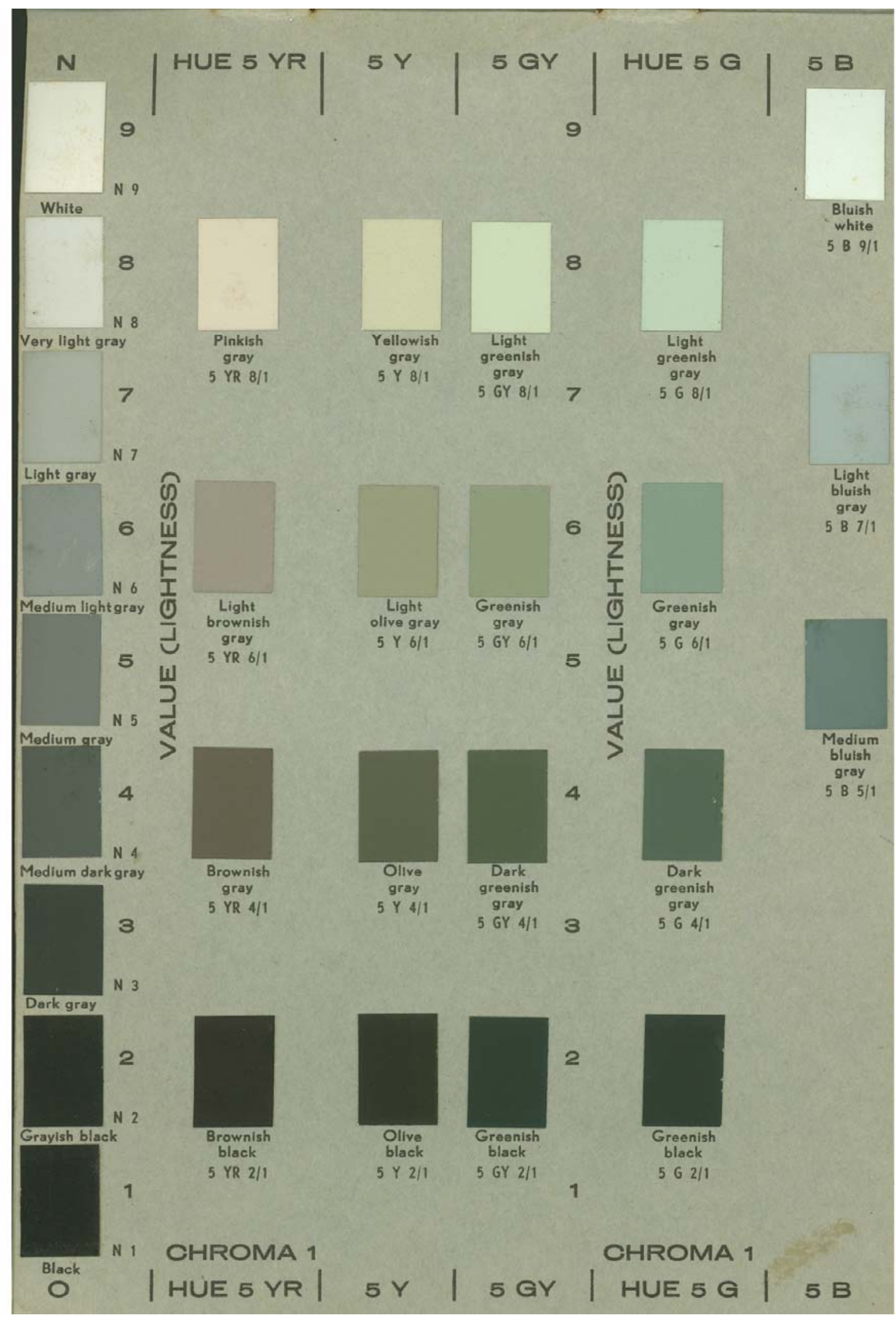

